\title{
100
}

UNITED STATES DEPARTMENT OF THE INTERIOR

Harold L. Ickes, Secretary

GEOLOGICAL SURVEY

W. C. Mendenhall, Director

\section{Bulletin 899}

\section{GEOLOGIC STRUCTURE AND} OCGURRENCE OE⿱

IN PART OF SOUTHY NEW YORK 崖这

W. H. BRADLEY, J. F. PEPPER, AND G. B-RIGi

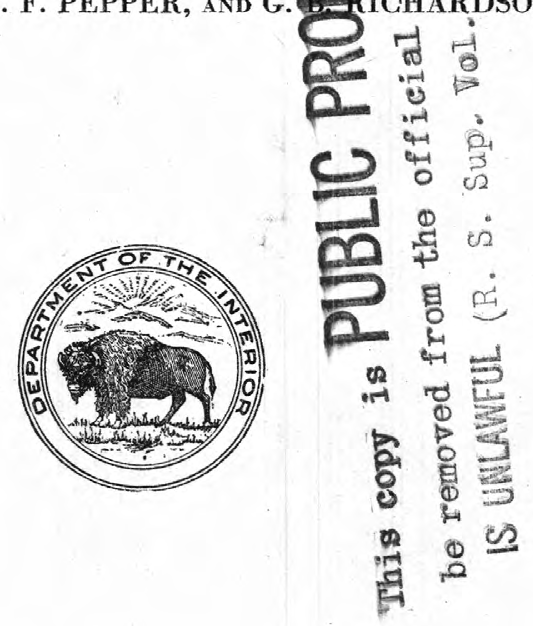





\section{CONTENTS}

[The letters in parentheses preceding the titles are those used to designate the papers for separate publication]

(A) Part 1. Structure and gas possibilities of the Oriskany sandstone in Steuben, Yates, and parts of the adjacent counties, by W. H. Bradley and J. F. Pepper

(B) Part 2. Subsurface structure in part of southwestern New York and mode of occurrence of gas in the Medina group, by G. B. Richardson.

\section{ILLUSTRATIONS}

Plate 1. Index map showing the location and extent of the area.......

2. Geologic map of Steuben, Yates, and parts of adjacent counties, New York In pocket

3. Columnar sections showing the lithologic units in the eastern,

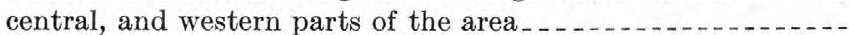

4. A, View southeastward down the Canisteo River; $B$, Detail of the plastically deformed sediments in the fault zone on Purdy Creek

5. Map of southwestern New York showing location of wells

6. Map showing isopach lines that represent intervals between the top of the Medina group and the top of the Onondaga limestone and between the top of the Onondaga limestone and

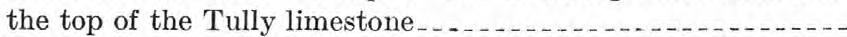

7. Map showing by contour lines drawn on the top of the Onondaga limestone the subsurface structure in part of southwestern New York, approximate outlines of principal gas-producing areas, and location of selected wells .............................

8. Map showing structure contour lines drawn on the top of the Medina group and location of selected gas wells and dry holes in part of Erie County.

Figure 1. Sketch showing a portion of the shale and sandstone zone, in the south bank of Slate Creek, that was deformed soon after deposition

2. Structure section across the reverse fault that trends northeastward along the valley of Purdy Creek.

3. Microfaults on the upper surface of a sandstone bed that was bent while still uncemented.

4. Map showing the southeastward thickening of the stratigraphic interval between the Oriskany sandstone and the base of the Rhinestreet shale and between the Oriskany and the base of the Dunkirk sandstone.

5. Map showing the structure of the Oriskany sandstone in the New York portion of the State Line gas field.............

6. Map showing the structure of the Oriskany sandstone in the

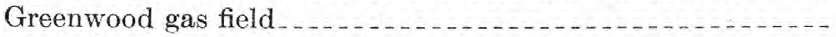

7. Map of the Wayne-Dundee gas field ...... 4

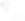



UNITED STATES DEPARTMENT OF THE INTERIOR

Harold L. Ickes, Secretary

GEOLOGICAL SURVEY

W. C. Mendenhall, Director

Bulletin 899-A

\section{GEOLOGIC STRUCTURE AND OCCURRENCE OF GAS IN PART OF SOUTHWESTERN \\ NEW YORK}

Part 1. STRUCTURE AND GaS POSSIBILITIES OF THE ORISKANY SANDSTONE IN STEUBEN, YATES, AND

PARTS OF THE ADJACENT COUNTIES

BY

W. H. BRADLEY and J. F. PEPPER

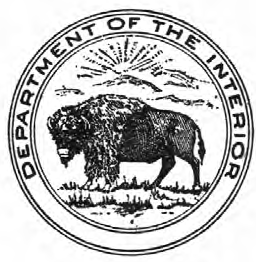

UNITED STATES

GOVERNMENT PRINTING OFFICE

WASHINGTON : 1938 


\section{NOTE}

The Geological Survey in 1934, 1935, and 1936 studied the geologic structure and the occurrence of natural gas in the Oriskany and Medina sandstones in a large part of southwestern New York. The geologists have prepared separate reports on the areas for which they were responsible. However, as these areas are adjacent and form a real unit both geographically and geolozically, the two reports are issued as parts of a single bulletin. No edition of the consolidated volume will be published, but the two parts may be bound together if desired. 


\section{CONTENTS}

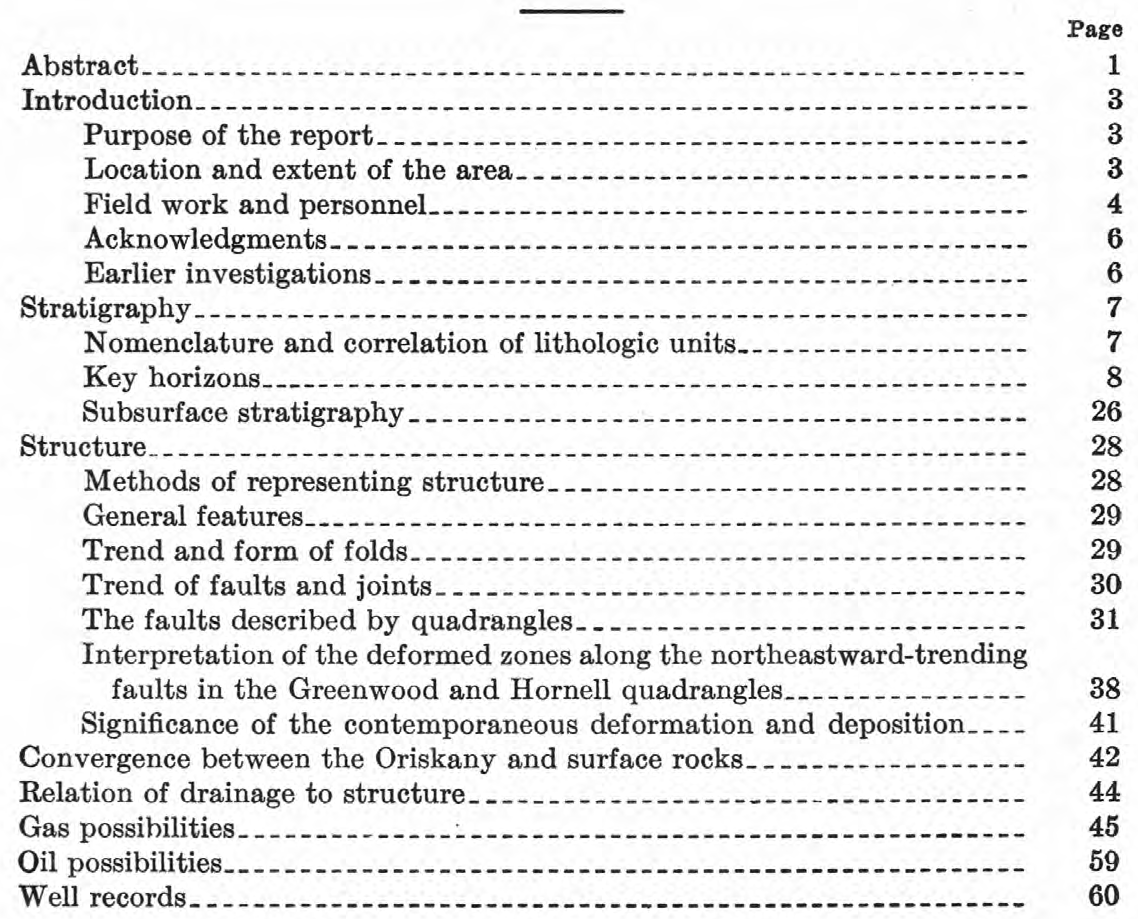

\section{ILLUSTRATIONS}

Plate 1. Index map showing the location and extent of the area.......

2. Geologic map of Steuben, Yates, and parts of adjacent counties, New York In pocket

3. Columnar sections showing the lithologic units in the eastern, central, and western parts of the area

4. $A$, View southeastward down the Canisteo River; $B$, Detail of the plastically deformed sediments in the fault zone on Purdy Creek

Figure 1. Sketch showing a portion of the shale and sandstone zone, in the south bank of Slate Creek, that was deformed soon after deposition

2. Structure section across the reverse fault that trends northeastward along the valley of Purdy Creek 
Figure 3. Microfaults on the upper surface of a sandstone bed that was bent while still uncemented

Page

4. Map showing the southeastward thickening of the stratigraphic interval between the Oriskany sandstone and the base of the Rhinestreet shale and between the Oriskany and the base of the Dunkirk sandstone......

5. Map showing the structure of the Oriskany sandstone in the New York portion of the State Line gas field............

6. Map showing the structure of the Oriskany sandstone in the Greenwood gas field....... 50

7. Map of the Wayne-Dundee gas field $\ldots$ 


\title{
GEOLOGIC STRUCTURE AND OCCURRENCE OF GAS IN PART OF SOUTHWESTERN NEW YORK
}

\section{PART 1. STRUCTURE AND GAS POSSIBILITIES OF THE ORISKANY SANDSTONE IN STEUBEN, YATES, AND PARTS OF THE ADJACENT COUNTIES}

\author{
By W. H. Bradley and J. F. Pepper
}

\begin{abstract}
The area covered by this report is in southwestern New York and includes a little more than 3,000 square miles in Steuben and Yates counties and parts of the six adjacent counties. This area has been mapped to determine the structural attitude of the exposed rocks, so as to aid those interested in prospecting for natural gas in the Oriskany sandstone of Lower Devonian age.

Because of the gentle regional dip toward the southwest, the youngest beds are exposed in the southwest corner of the area, and progressively older beds crop out northeastward in successive bands that strike generally northwest. All the exposed rocks are of Upper Devonian age except those in a narrow belt at the extreme north edge of the area, where a small thickness of Middle Devonian rocks crops out. The maximum thickness of beds so exposed is nearly 4,000 feet, of which the lower part is predominantly soft dark shale and the upper part predominantly fine-grained sandstone and gray shale. All the beds are marine except a few tongues of continental deposits-red shale and sandstone and gray mudstone-in the youngest beds. All the beds thicken southeastward, so that there is a northwestward convergence between any two lithologic units in the series. More than 30 key horizons that are persistent and distinctive were mapped, and altitudes on these key horizons served as a basis for constructing the structure contour map. Many of the key horizons are formation or member boundaries, but others are the tops or bottoms of limestone or sandstone beds within formations. All the stratigraphic units mapped are purely lithologic. (See pl. 2.)

The Tully limestone, which crops out along the northern border of the area, is an easily recognizable and therefore valuable key bed for subsurface correlations in this part of the State. Below the Tully limestone is a thick body of Middle Devonian shales of the Hamilton group which rests on another valuable key bed, the hard, cherty Onondaga limestone, also of Middle Devonian age. Below the Onondaga limestone is the Lower Devonian Oriskany sandstone, which is the gas-producing bed. Unlike the Onondaga, the Oriskany is locally thin or absent.
\end{abstract}


The structure of most of the area is shown by contour lines at 25-foot intervals, but where key horizons are lacking the structure is indicated by dip symbols. Upon the regional south and southwest dip are superposed numerous gentle folds whose axes trend approximately northeastward in the greater part of the area but more nearly eastward in the eastern part. The folds generally tend to become narrower and steeper, and therefore more closely spaced, southwestward. Many of the anticlines fork southwestward, whereas the synclines tend to fork northeastward. All the folds have a westward or southwestward plunge.

Throughout the area the rocks are jointed in two dominant sets-one that trends northwest and the other east or northeast. No evident relation between these joints, which were measured only in the hard, relatively brittle beds, and the individual folds or domes was discernible.

The faults are concentrated in the northeastern and southwestern parts of the area and trend either northeastward or northwestward. Some are nearly vertical normal faults; others are steep reverse faults. Subsurface data show that most of the faults increase in throw downward and also that many subsurface faults do not reach the surface. A group of faults in the northwestern part of the Greenwood quadrangle and the southwestern part of the Hornell quadrangle were active during Upper Devonian time, while the Gowanda shale and overlying beds were being deposited. At this stratigraphic horizon the beds in a zone a few hundred feet thick are highly deformed in a wide belt on both sides of the faults. Sandstone layers are thinned out into long stringers or swollen into thick masses and in places are bent acutely without fracture. Thin layers of shale, coquina, and sand have flowed together into intricately plicated zones that lack cleavage and joints. These features show that the sediments were deformed while wet and plastic and buried only a little way below the sea floor. The beds that were laid down over these disturbed zones were not involved in this deformation. Many of the sharper flexures and most of the faults are not evident in the beds several hundred feet stratigraphically higher. Accordingly, broad, gentle folds in these higher beds in parts of the area south and west of the northwest corner of the Greenwood quadrangle may conceal, at considerable depths below them, narrow folds separated by abrupt flexures or faults.

Several of the larger streams and rivers occupy strike valleys, and their courses swing to follow the changing strike of the rocks where they cross successive folds. But, with few exceptions, the small streams are not adjusted to the bedrock structure.

Domes likely to serve as traps for natural gas are concentrated in the northeastern and southwestern parts of the area. The Wayne-Dundee gas field is in the northeastern part. All the other potentially valuable domes in this part of the area have been drilled and found valueless except one small structural feature in the southern part of the Ovid quadrangle, which, if the Oriskany is present, may trap a small quantity of gas.

In the Greenwood quadrangle in the southwestern part of the area there is one gas field and four well-defined domes, all of which may be productive if the Oriskany sandstone is present. In the northwest corner of the quadrangle the dips indicate at least two domes that can be adequately defined and evaluated only by geophysical prospecting. The State Line gas field is in the Wellsville quadrangle. In the southeast corner of this quadrangle there are three other domes of comparable size that may also be productive if underlain by the Oriskany sandstone. At other places in the Wellsville quadrangle the dips suggest several anticlinal axes on which analogous productive domes may 
be found. The structural features in this quadrangle, however, are defined by contours only in the southeastern part. In the Woodhull quadrangle a large dome east of Jasper may be productive, and the western top of the large Woodhull dome in the southwestern part of the quadrangle seems to warrant drilling, despite the absence of the Oriskany in a well on the eastern top. Two wells drilled in 1936 and 1937 a little northeast of a broad, nearly flat-topped dome in the Hornell quadrangle, a few miles east of Hornell, struck small flows of gas, suggesting that wells drilled higher on this dome may be productive.

In much of the southwestern part of the area seismograph surveys should be of great value in determining the structure at the Tully and Onondaga horizons. Without abundant subsurface control of this sort, the danger of drilling into subsurface faults can hardly be overemphasized.

Three closed or nearly closed synclines in the Greenwood and Wellsville quadrangles appear to be favorable places to drill for oil in the shallow sandspresumably parts of the Dunkirk sandstone.

\section{INTRODUCTION}

\section{PURPOSE OF REPORT}

Since the discovery of the Wayne-Dundee gas field in 1930 and the more recent discovery of large quantities of gas in the Oriskany sandstone about 2 miles north of the village of Greenwood the search for similar favorable structural features has been greatly stimulated in the Finger Lakes region and southwestward to the Pennsylvania line. To aid those interested in the area to gain a clearer understanding of the regional structure and its relation to the subsurface structure, parties in charge of the senior author were assigned during the field seasons of 1934 and 1935 to make a geologic study of Steuben County and parts of the adjacent counties. As a result of this survey 10 domes that warrant test drilling have been mapped. In addition several other anticlines that warrant further study were found. Although it was not originally the purpose to search for new oil pools, the construction of a regional structure map has revealed at least three synclines which apparently have not been adequately tested for oil but which, by analogy with other nearby oil fields, may be productive. The initiation of this project was made possible through an allotment of funds from the Public Works Administration, but since July 1, 1935, the investigation has been continued on funds from the regular appropriations of the Geological Survey, of the United States Department of the Interior.

\section{LOCATION AND EXTENT OF THE AREA}

As shown by plate 1, the area described in this report is in the southwestern part of New York and includes all of Steuben and Yates Counties and parts of six adjacent counties-Chemung, Schuyler, Seneca, Ontario, Livingston, and Allegany-a total area of a little more than 3,000 square miles. 
Seven of the Finger Lakes are included in the northern part of this area, and tributaries to them drain a little more than a third of region mapped. Flowing diagonally southeastward across the central part of the area are the Cohocton and Canisteo Rivers. These join the Tioga River in the southeast corner of the area to make the Chemung River, which is one of the principal tributaries of the Susquehanna. The Genesee River and its tributaries drain the western part of the area. The city of Elmira is in the southeast corner of the area, Canandaigua is at the north edge, and Wellsville is in the southwest corner. Within the area are other well-known cities, towns, and villages-Corning, Watkins, Penn Yan, Bath, Hornell, and Dansville.

About 650 square miles of the area shown on plate 2 was not mapped by the Geological Survey parties but was mapped by Charles E. Fralich, of Bradford, Pa., who kindly gave the writers a copy of the map for inclusion in this report. (See index map on pl. 2.) A part of the map made by Fralich and his associates was published in $1932,{ }^{1}$ but the rest has not heretofore been published.

The entire area has been mapped topographically by the Geological Survey in cooperation with the New York State Department of Public Works. As shown on plate 2, parts or all of the following 15-minute quadrangles are included: Honeoye, Canandaigua, Phelps, Geneva, Nunda, Wayland, Naples, Penn Yan, Ovid, Canaseraga, Hornell, Bath, Hammondsport, Watkins, Wellsville, Greenwood, Woodhull, Corning, and Elmira.

\section{FIELD WORK AND PERSONNEL}

The greater part of the field work upon which this report is based was done in 1934 between late May and early November. During that time the party included six geologists-the authors and G. B. Richardson, of the Geological Survey, G. H. Chadwick, H. N. Eaton, and H. R. Blank-and four field assistants-N. S. Wagner, A. E. Wood, J. W. Sadler, and M. C. Baker. After about 1 month Mr. Blank was transferred to the water-resources branch of the Geological Survey, and Mr. Baker left to accept a position with an oil company in Texas. In 1935 field work on the project began late in May and ended late in September. Mr. Pepper spent about a month in May and June 1935 in the Wayland and Naples quadrangles and the rest of the season mapping the Woodhull quadrangle and part of the Hornell quadrangle. In June 1935 Mr. Bradley, assisted by D. W. St. Clair,

\footnotetext{
1 Torrey, P. D., Fralich, C. E., Young, W. H., Brewer, C., and Phillippi, P. M., The geology of New York and northern Pennsylvania: Am. Petroleum Inst. Paper 826-4 A, fig. 7, 1932. Fox, I. W., Geology of part of Finger Lakes region, N. Y.: Am. Assoc. Petroleum Geologists Bull., vol. 16, p. 687, 1932.
} 


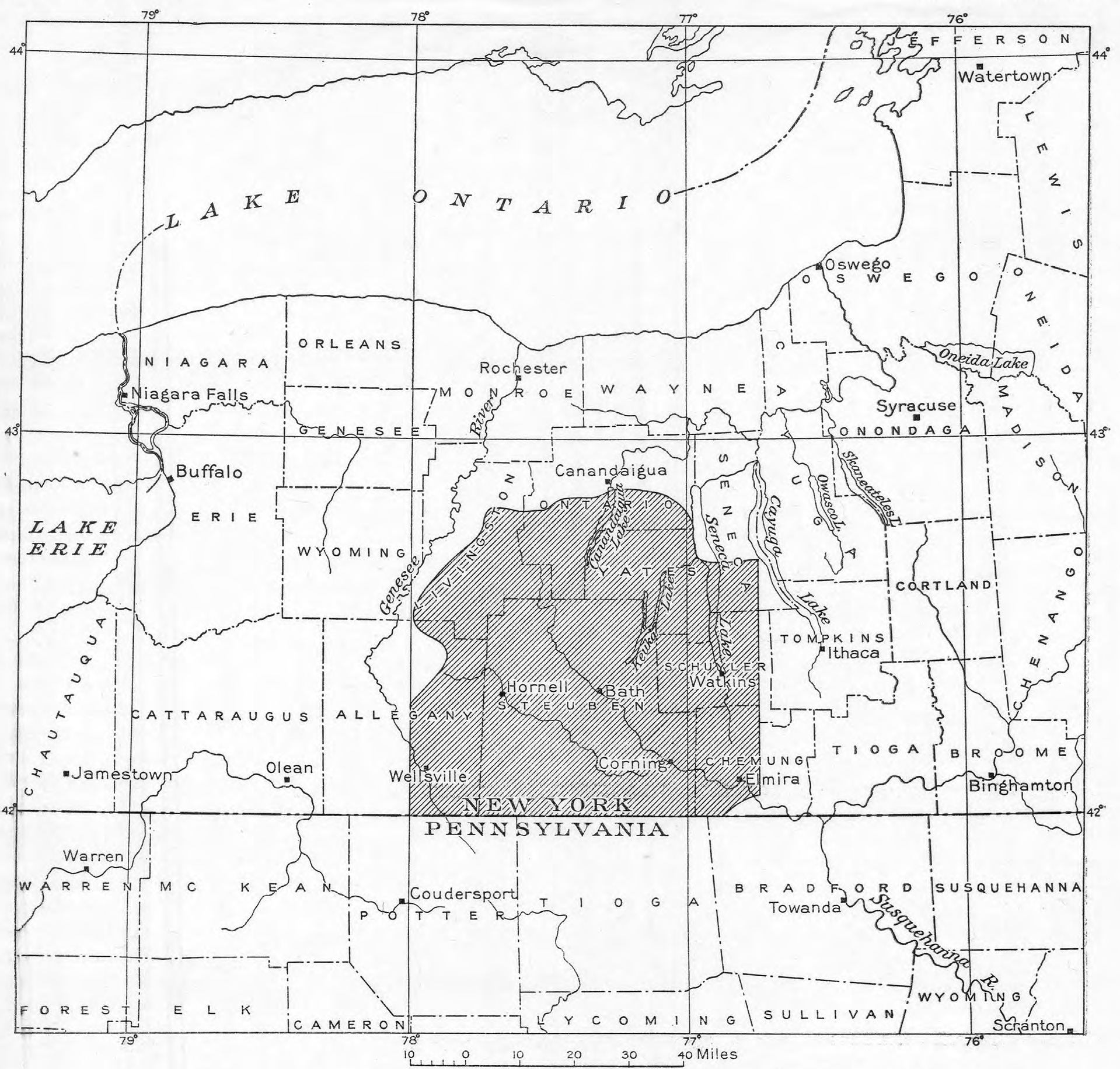

INDEX MAP SHOWING THE LOCATION AND EXTENT OF THE AREA DISCUSSED IN THIS REPORT. 
mapped parts of the Ovid quadrangle, and in subsequent months mapped the Greenwood quadrangle. The report was written by Mr. Bradley, but Mr. Pepper assisted in its preparation during the winters following both field seasons.

Mr. Richardson collected and studied subsurface data in a considerable part of western New York, and the results of his work will be published as a separate report. ${ }^{2}$ Mr. Chadwick devoted nearly all his time to a study of the stratigraphy. As a result of his work several lithologic units of formation rank were traced eastward from the meridian of Olean, N. Y., into the area covered by this report, where they were used as key beds for determining the structure. Mr. Chadwick's work also contributed much to the general understanding of the relations between the lithologic units and the faunal zones of the Upper Devonian of this part of the State.

Pleistocene glacial drift and soil form a cover over this region nearly everywhere, so that the bedrock exposures are restricted to stream beds, road cuts, and quarries. Moreover, a broad belt extending southeastward across the area near the south ends of the Finger Lakes is deeply buried beneath a great terminal moraine. In that belt exposures of rock are exceedingly rare, even in the streams. It is impossible, therefore, to trace key beds continuously. Accordingly the structure of the rocks was determined by traversing the streams and roads and measuring altitudes on individual key horizons or groups of them and observing the dip and strike of the beds wherever the exposures were adequate.

Most of the altitudes were measured with Tycos surveying aneroids, but a few were measured by hand leveling, and in the Greenwood and Ovid quadrangles a considerable number were measured by plane-table and stadia traverses. The plane-table traverses were made on scales of 1 to 12,000 and 1 to 1,250 . In determining altitudes with aneroids considerable care was taken to see that the time elapsed between readings at a benchmark, at the point on the key horizon, and at the benchmark again was kept at a minimum, so as to reduce as much as possible the error due to changes in barometric pressure. In correcting the readings it was assumed that the rate of change of barometric pressure was uniform. Obviously the accuracy of the altitudes determined at the large number of stations all over the area is not uniform. Where the benchmarks are numerous and the points to be determined are easily accessible the accuracy is much greater than elsewhere. But the altitudes of many of the points are averages of two or more readings made at different times,

${ }^{2}$ Richardson, G. B., Subsurface structure and convergence in part of western New York and relation of occurrence of Medina gas to structure and stratigraphy: U. S. Geol. Survey Bull. 899-B [in preparation]. 
and the relation between altitudes determined first with aneroids and later by plane-table traverses leads to the belief that most of the altitudes used in the preparation of the structure-contour map are probably not more than 15 feet above or below the true figures and that many of them have a smaller limit of error than that. Many dips were measured from the relative altitudes of three points determined with a stadia hand level and an 8-foot stadia rod, but more than half the dips recorded were measured with Brunton compasses.

\section{ACKNOWLEDGMENTS}

The authors wish to express here their thanks to the New York State Museum and members of its staff for copies of various published maps and reports and also for subsurface data. They are especially grateful to Mr. Charles E. Fralich, of Bradford, Pa., for his permission to publish as part of plate 2 his maps of the Penn Yan quadrangle and parts of several adjacent quadrangles. Also many of the key horizons which he used were picked up by the Geological Survey parties and extended northwestward and southeastward. Mr. Fralich also contributed many subsurface data which have been used in this report. The authors wish also to thank Dr. E. R. Eller, of the Carnegie Museum, for the location and approximate altitudes of several key beds in the southwest corner of the Hornell quadrangle and the southeast corner of the Canaseraga quadrangle.

\section{EARIIER INVESTIGATIONS}

It would serve no useful purpose to list the long series of geologic reports and scientific papers that have been published on this part of the State during the past 100 years; therefore only those reports or papers that seem strictly pertinent to the structure and gas possibilities of the area shown on plate 2 are cited here.

Williams, H. S., The undulations of the rock masses across central New York: Am. Assoc. Adv. Sci. Proc., vol. 31, p. 412, 1882.

Williams, S. G., Dip of the rocks of central New York: Am. Jour. Sci., 3d ser., vol. 26, pp. 303-305, 1883.

Williams, H. S., Tarr, R. S., and Kindle, E. M., U. S. Geol. Survey Geol. Atlas, Watkins Glen-Catatonk folio (no. 169), pp. 13-15, 1909.

Sheldon, Pearl, Some observations and experiments on joint planes: Jour. Geology, vol. 20, pp. 53-79, 164-183, 1912.

Torrey, P. D., Natural gas from Oriskany formation in central New York and northern Pennsylvania: Am. Assoc. Petroleum Geologists Bull., vol. 15, pp. 671-684, 1932.

Torrey, P. D., Fralich, C. E., Young, W. H., Brewer, C., and Phillippi, P. M., The geology of New York and northern Pennsylvania: Am. Petroleum Inst. Paper 826-4 A, 19 pp., 1932.

Fox, I. W., Geology of part of Finger Lakes region, N. Y.: Am. Assoc. Petroleum Geologists Bull., vol. 16, pp. 675-690, 1932. 
Newland, D. H., and Hartnagel, C. A., Review of the natural gas and petroleum developments in New York State: New York State Mus. Bull, 295, pp. 101-184, 1932.

Newland, D. H., and Hartnagel, C. A., Recent natural-gas developments in south-central New York: New York State Mus. Circ. 7, 20 pp., 1932.

Wedel, A. A., Geologic structure of the Devonian strata of south-central New York: New York State Mus. Bull. 294, 74 pp., 1932.

Robinson, J. F., Jones, V., and Gaddess, J., Subsurface structural geology of the northern Pennsylvanian and southern New York gas fields: Pennsylvania State Coll., Min. Industries Exper. Sta., Bull. 11, pp. 9-18, 1932.

\section{STRATIGRAPHY}

\section{NOMENCLATURE AND CORRELATION OF ITTHOLOGIC UNITS}

The primary function of the geologic work in this area was to determine the structure. Accordingly the stratigraphy was studied with the specific object in mind of selecting key horizons that are persistent and distinctive enough to be surely identified. Many of the key horizons are formation or member boundaries, but others are boundaries of limestone or sandstone beds within formations. All the stratigraphic units mapped are purely lithologic. The relation between the faunas and these lithologic units is a stratigraphic problem of great interest and one that must be solved before a full understanding of the Upper Devonian stratigraphy can be even approached. That problem lies distinctly beyond the scope of this project, but the authors hope that the detailed tracing of these units may serve a useful purpose, apart from their economic value, in stimulating equally detailed paleontologic work which will relate plainly the rich fauna and its various facial changes to the lithologic units.

In general the nomenclature of the rock units used in this report follows that adopted by the New York State Museum. Many of the units have been traced eastward and westward from their type locality near Canandaigua Lake. Others, particularly the higher beds, were traced into the area by Chadwick from their type localities in the extreme western part of the State. In advance of the detailed mapping Chadwick also traced the formations through the western and southwestern part of the area and made several reconnaissance maps showing the distribution of the formations. In the detailed, mapping of the greater part of the area virtually every exposure of the key horizons was located and its altitude determined. The key horizons were identified in part by their own peculiarities but also by the characteristics of the beds above and below them and by their relations to other key horizons in the section. Not all the key horizons used are of equal value for determining the structure. Thin persistent limestone beds overlain and underlain by thick series of 
rocks free from limestone are best, but the horizons where the lithology changes abruptly from a series of flagstones ${ }^{3}$ to jet-black shale are nearly if not quite as good. Horizons marked by transitional changes in lithology are of little value, and lenticular groups of sandstone and shale beds are in places so uncertain that they were either not mapped at all or were used only as control for 100-foot contours.

\section{KEY HORIZONS}

Because all the sedimentary rocks in this part of the State have a regional south or southwest dip, successively older rocks are exposed at the surface from south to north. Thus, a few miles north of the contoured area shown on plate 2 , the oldest formation referred to in this report-the gas-producing Oriskany sandstone-crops out. About 65 miles to the southwest, in the southeastern part of the Wellsville quadrangle, is the outcrop of the youngest bed mapped. Of this whole series of formations the oldest shown on plate 2 is the Tichenor limestone member of the Ludlowville shale, a formation in the Hamilton group. The beds below the Tichenor are known only from well records within the area covered by this report and are therefore considered on pages 26-28 under the heading "Subsurface stratigraphy."

In the following descriptions the intervals between key horizons are not given, because they differ from place to place. The intervals' between key horizons in the western, central, and eastern parts of the area, however, are shown in the columnar sections of plate 3.

Horizon TI.-The top of the Tichenor limestone, which is a member of the Ludlowville shale, is horizon TI. The member is a crinoidal limestone bed, 1 to 2 feet thick, overlain and underlain by somewhat limy fossiliferous bluish-gray shale. The name Tichenor is used here in the sense adopted by the New York State Museum ${ }^{4}$ and does not include about 10 feet of the underlying shale that Cooper ${ }^{5}$ proposed to unite with the limestone to form his Tichenor member.

Horizon M.-The top of the Menteth limestone, which is the basal member of the Moscow shale, is horizon M. This member is a hard

\footnotetext{
${ }^{3}$ The term "flagstone" (or simply "flags") is probably more commonly used in this part of the United States than elsewhere. It was originally applied to the regular beds of hard bluish-gray fine-grained argillaceous sandstone that in the past were so extensively quarried for paving stone. The term has come to be generally used by the local geologists in a slightly broader sense to include all beds of hard bluish-gray finegrained argillaceous sandstone, whether these beds are thin and regular or thick, massive, and somewhat irregular. It is used in this broader sense in this report.

4 Goldring, Winifred, Handbook of paleontology: New York State Mus. Handbook 10, p. $393,1931$.

${ }^{5}$ Cooper, G. A., Stratigraphy of the Hamilton group: Am. Jour. Sci., 5th ser., vol. 19, p. $226,1930$.
} 
bluish-gray argillaceous limestone about 1 foot thick that is overlain and underlain by gray shale. This limestone is characterized, at least locally, by silicification of the fossils.

Horizon T.-The top of the Tully limestone is horizon T. In the northeastern part of the area the Tully is 12 to 14 feet thick and is made up of massive or thick-bedded hard bluish-gray to nearly black limestone that generally weathers buff or light gray. It thins northwestward and near the east shore of Canandaigua Lake loses its identity. West of Canandaigua Lake the limestone is represented by a nodular pyrite layer. The Tully is underlain by gray fossiliferous shale and overlain by jet-black shale. Because in this area the top of the limestone is sharply defined and generally better exposed than the base, it was used as the key horizon.

For a full discussion of the Tully limestone and the Hamilton group the reader is referred to two recent papers by Cooper. ${ }^{6}$

Above the Tully limestone is a unit of jet-black shale called the Geneseo shale-the basal formation of the Genesee group-as proposed by Chadwick. ${ }^{7}$

Horizon G.-The Genundewa limestone lentil, which lies at the top of the Geneseo shale, is a bed of black or very dark-gray limestone, in most places less than a foot thick. Locally, however, there are one, two, or three thin layers of similar limestone spaced several feet apart in the overlying shale. The base of the lowest of these, limestone layers was used as key horizon G. The limestone is distinguished by a phenomenal abundance of a small pteropod, Styliolina fissurella.

At Firtree Point, on the west shore of Seneca Lake, in the Watkins quadrangle, the Genundewa appears to be abnormally thick. The following section was measured in the small stream that enters the lake on the north side of the point:

\section{Section in stream north of Firtree Point}

West River shale:

Fit. in.

Shale, gray, fissile, with numerous thin, gently crossbedded siltstone layers.

Shale, dark gray, fissile; grades upward to papery black shale at the top

Concretions, ellipsoidal, dense, limy; make a welldefined layer.

Shale, gray, fissile and somewhat silty

Shale, gray, limy, hard and coarsely fissile

${ }^{6}$ Cooper, G. A., Tully formation of New York: Geol. Soc. America Bull., vol. 46, pp. 781-868, 1935; Stratigraphy of the Hamilton group: Am. Jour. Sci., 5th ser., vol. 19, pp. 116-134, 214-236, 1930.

${ }^{7}$ Chadwick, G. H., Large fault in western New York: Geol. Soc. America Bull., vol. 31, p. $118,1920$. 
Geneseo shale (Genundewa limestone lentil) :

Ft. in.

Limestone, dark gray, hard, weathering brownish gray; contains in abundance a small branching

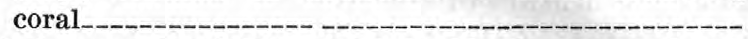

Shale, gray, hard, limy; with hackly fracture and containing thin lenses of muddy limestone

Limestone, gray, muddy, hard, massive; weathers brownish gray

Shale, gray, hard, limy

Limestone, nearly black, hard and massive but shaly near the base; weathers light brownish gray and contains an abundance of a small branching coral_-

Shale, dark gray and very limy

Limestone, nearly black, hard, muddy, shaly at the base; weathers light brownish gray and contains zones of a small branching coral (base of Genundewa limestone lentil)

Shale, jet black, massive to fissile (down to level of Seneca Lake)

The limestone and limy shale in this vicinity differ in their proportions along the strike, so that in some ravines the unit is nearly all massive limestone with thin shale partings and in others nearby the limestone layers are subordinate, but the general sequence persists and was recognized on the east shore of the lake, where, however, only the upper limestone beds are exposed above the lake level. Although specimens of these limestone layers were examined carefully only a few of the small pteropods (Styliolina fissurella) that characterize the Genundewa limestone farther north along Seneca Lake and in areas to the west were found. Nevertheless, it seems probable that this limestone is a thicker facies of the Genundewa for, as Lincoln ${ }^{8}$ and Williams ${ }^{9}$ showed, this limestone unit at Firtree Point is correlative with the limestone near the foot of the falls in Lodi Glen on Mill Creek (Ovid quadrangle), and the limestone in Lodi Glen contains an abundance of the small pteropod (Styliolina fissurella) and is therefore the typical Genundewa limestone. This limestone Bradley mapped along the east side of Seneca Lake in the Ovid quadrangle, and several years earlier C. E. Fralich had mapped it along the west shore.

For structural control in the vicinity of Firtree Point Fralich measured altitudes on the top of the uppermost limestone layer,

\footnotetext{
${ }^{8}$ Lincoln, D. F., Report on the structural and economic geology of Seneca County : New York State Museum 48th Ann. Rept., vol. 2, p. 99, 1895.

${ }^{2}$ Williams, H. S., Tarr, R. S., and Kindle, E. M., U. S. Geol. Survey Geol, Atlas, Watkins Glen-Catatonk folio (no. 169), p. 7, 1909.
} 
whereas on the east shore the concretionary zone above the limestone was used as a key horizon because it was exposed for a greater distance.

Horizons $S$ and $C$.-Overlying the Genundewa limestone are the West River shale and the Standish flagstone, a unit of alternating flags and silty gray shale. These two formations are complementary to one another - the Standish thickens eastward and the West River thickens westward. 'Together they occupy the interval in the stratigraphic column between the Middlesex shale and the Genundewa limestone lentil of the Geneseo shale. Eastward as the Standish thickens and replaces the West River the interval between the Genundewa and the Middlesex increases. (See pl. 3.) In the vicinity of Canandaigua Lake the Standish is represented by only about 15 feet of thin regular flagstone layers between the West River shale and the Middlesex shale. In the vicinity of Seneca Lake the Standish is represented by a thick series of massive flags, whereas the West River is represented by only about 50 feet of gray silty shale and a smaller amount of black shale.

Near the base of the Standish at the south end of Seneca Lake is a bed of dense, massive fine-grained muddy sandstone or siltstone about 2 feet thick whose top has been designated horizon $\mathrm{S}$. This bed is best exposed a little above road level at the Seneca Lake inlet a mile east of Watkins and at road level about a mile south of Watkins. Its top was used as a key horizon only in a small area near the south end of Seneca Lake.

Northwestward near Keuka Lake, where the Standish and West River are about of equal thickness, the base of the Standish is marked by a dense, massive flagstone similar to the bed whose top is horizon $\mathrm{S}$ but somewhat thicker and overlain by a group of closely spaced thinner flags. The base of the massive flagstone layer is horizon C. It was used mostly by Fralich around Keuka Lake, but he also traced it eastward to Seneca Lake and thence southward a few miles. Bradley used it in the Ovid quadrangle east of Seneca Lake. It loses its identity in the southern part of the Ovid quadrangle, where the Standish begins to thicken rather rapidly. Horizon $\mathrm{C}$ is well exposed about 6 miles south of Penn Yan in the ravines along the east arm of Keuka Lake, 50 to 60 feet above the lake level.

Horizon BP.-Key horizon $\mathrm{BP}$ is marked by a flagstone stratum only a few inches thick that is overlain and underlain by gray silty shale. This bed was mapped by Fralich and his associates around both arms of Keuka Lake, in the Penn Yan quadrangle, and they also found it on a stream less than 1 mile west of the village of Himrod, in the Ovid quadrangle. 
Horizons $M B$ and $M T$.-Key horizons MB and MT are respectively the base and top of the Middlesex shale, a unit of jet-black shale through the greater part of the area. The Middlesex is sharply defined both at the base, where it overlies the gray silty shale and thin flagstones of the Standish, and at the top, where it is overlain by the gray Cashaqua shale. These two horizons were mapped in parts of the area between a point 3 miles west of Cheshire, in the Canandaigua quadrangle, and the southwest corner of the Ovid quadrangle. They are both well exposed in the lower part of a ravine 2 miles north of the north end of the west arm of Keuka Lake, in the Penn Yan quadrangle.

Horizon MF.-Eastward and southward from the southwestern part of the Ovid quadrangle the lithology of the Middlesex changes rather abruptly. Massive flagstones come into the upper half and virtually displace the shale. The lower half, though it persists as an exclusively shale unit, changes to gray silvery shale. At the base of the flagstone portion of the Middlesex in this part of the area is a massive flagstone 3 to 6 or more feet thick whose base is key horizon MF, which was used in the Watkins quadrangle and in the eastern part of the Ovid quadrangle. The abruptness of this lithologic change in the Middlesex is shown in Glen Creek west of Watkins. About a mile west of the town the flagstone and shale units are exposed in the north wall of the ravine, but the flagstone unit thins westward so rapidly that where it crosses the creek less than a mile farther west it is reduced to only a few thin layers of flagstone, the remainder having been replaced laterally by gray shale. Horizon MF is well exposed in the center of the village of Odessa, in the southeastern part of the Watkins quadrangle, where a low dam has been built upon the massive basal flagstone layers. The bluish-gray flaky shale unit is exposed in the short gorge downstream. The Middlesex has heretofore not been traced this far southeast.

Horizon $C F$.-Overlying the Middlesex shale is the Cashaqua shale. In the Watkins and Ovid quadrangles the Cashaqua consists of two nearly equal parts, the lower all shale and the upper a series of alternating flagstones and shale. This upper series of flagstones the authors propose to call the Rock Stream flagstone member of the Cashaqua shale, from its exposures on Rock Stream, in the northwestern part of the Watkins quadrangle, where it is 180 feet thick. The contact between the base of this flagstone member and the underlying shale is sharply defined and is horizon CF, which has been mapped in the Watkins quadrangle and the southeastern part of the Ovid quadrangle. The top of this member is defined by the Parrish limestone lentil, which overlies it. 


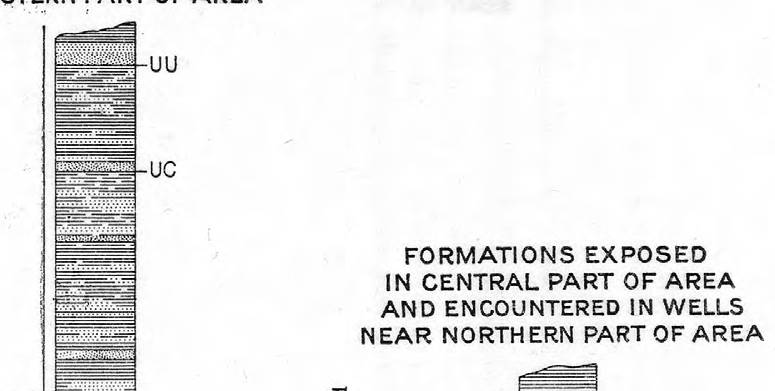
EAR NORTHERN PART OF AREA

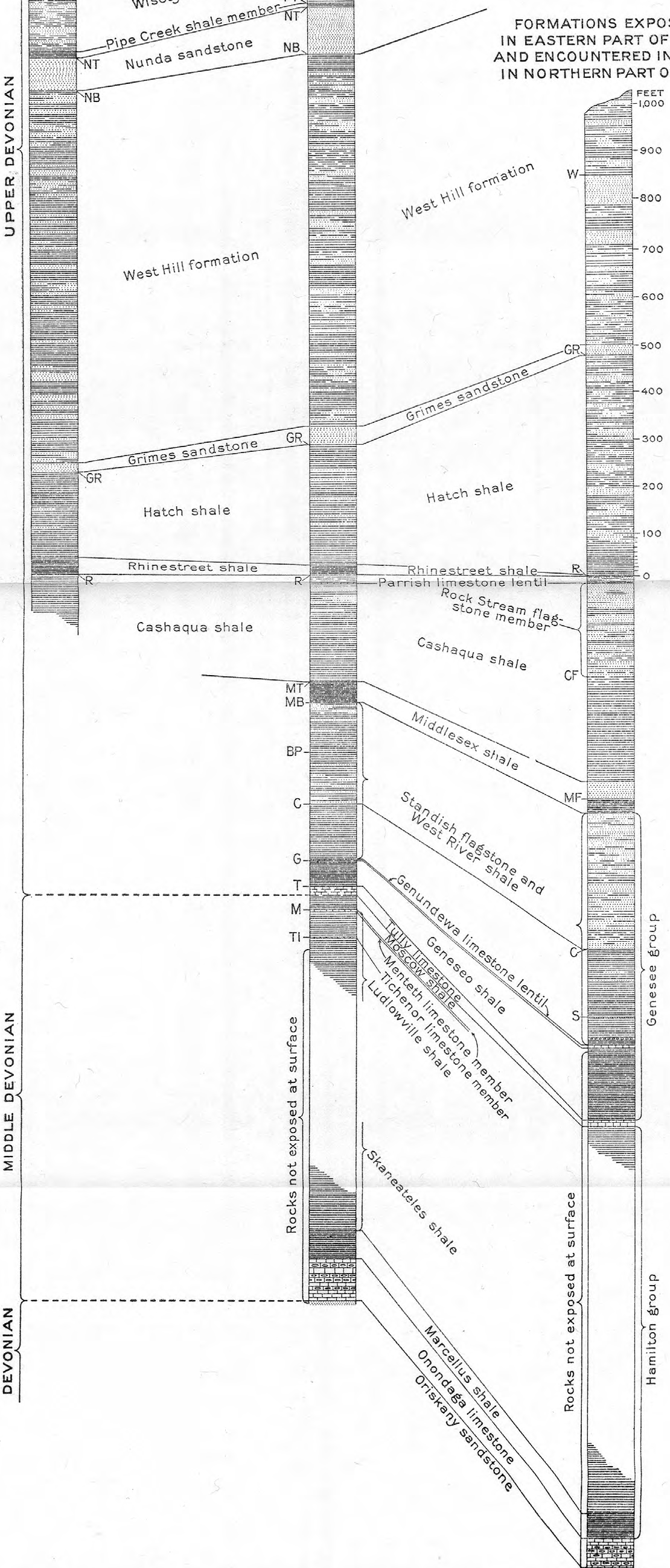


Northwestward the Rock Stream flagstone member thins and is replaced by shale. On the west side of Keuka Lake it is represented by only a few thin flagstones and beds of silty shale in the upper part of the Cashaqua. A little farther west the Cashaqua is all shale.

Horizon R.-The Cashaqua is overlain by the Rhinestreet shale, a persistent unit of jet-black shale that ranges in thickness from about 50 feet near Conesus Lake, in the northwestern part of the area, to about 3 feet at the east edge of the Watkins quadrangle, about 55 miles to the southeast. The base of the Rhinestreet is everywhere sharply defined and is key horizon $\mathrm{R}$, on which the structure contours of the northeastern half of the area mapped on plate 2 were drawn. Only 10 to 20 feet below the base of the Rhinestreet is another equally good key bed, the Parrish limestone lentil of the Cashaqua shale, which was also mapped over the greater part of the area. Its outcrop is not shown on plate 2 , however, because on the scale of the map its outcrop would be practically coincident with that of the base of the Rhinestreet. The Parrish limestone is a rather crudely bedded nodular muddy light-gray to buff limestone unit that ranges in thickness from a few inches to about 4 feet. The limestone is characterized by its yellowish weathered surface, by an abundance of solution cavities, and, locally at least, by an abundance of goniatites. It is a lens, the western edge of which is a few miles west of the center of Canandaigua Lake and the eastern edge is near the east line of the Watkins and Ovid quadrangles. In the western part of the area it is about 20 feet below the base of the Rhinestreet shale and is separated from the Rhinestreet by gray silty shale. Below the limestone in that region is silty gray shale with a fer thin beds of shaly flagstone. In the southeastern part of the area the Parrish and Rhinestreet are separated by 10 or 12 feet of rather soft lumpy sandstone that is muddy and locally shaly. Below the Parrish is the Rock Stream flagstone member, a thick series of flagstone layers that are more numerous and more massive just below the limestone. The Rhinestreet shale, the Parrish limestone lentil, and the associated beds are well exposed in the many steep ravines along the southern parts of Canandaigua and Keuka Lakes.

Horizon GR.-The black shale of the Rhinestreet grades upward rather abruptly into the silty gray Hatch shale. In the northwestern part of the area the Hatch contains a considerable quantity of darkgray and black shale interbedded with the gray, but southeastward the formation thickens and grows progressively lighter gray and more sandy. In the southeastern part of the area the silty gray shale is interbedded with a large number of thin regular flagstones and locally groups of thicker flags that aggregate several feet in thick- 
ness. Over the greater part of the area, however, the Hatch is virtually all shale and is overlain by the Grimes sandstone, the base of which is horizon GR. At its type locality in Grimes Creek a mile northwest of the village of Naples the Grimes is 40 feet thick. There it has at its base massive flagstones 7 feet thick. These are followed by a rather closely spaced series of similar flagstone or sandstone beds that are separated by thinner units of sandy shale or shaly sandstone. The massive flags at the base of the Grimes make the lip of the second high falls in the main fork of Grimes Creek. Below these massive flags, at the top of the Hatch, is a shale unit 13 feet thick that contains several thin regular flagstone layers and one very thin, fossiliferous limestone layer. Below this 13-foot unit is a pair of flagstones nearly 2 feet thick, and below them is a body of dark-gray shale 60 feet thick that makes the face of the falls. This thick shale unit below the Grimes persists over a large part of the area and is helpful in identifying the Grimes.

The base (GR) of the Grimes was mapped by Pepper south of Conesus, Hemlock, and Honeoye Lakes. In the Hammondsport and Watkins quadrangles Bradley used the horizon GR and traced it still farther south into the Elmira quadrangle. But in the southeastern part of the area the Grimes is not a wholly satisfactory key bed, because it is variable in thickness and lithology and because at least one other comparable unit of sandstone comes into the underlying Hatch shale in that vicinity.

Horizon W.-The Grimes sandstone is overlain by the West Hill formation (West Hill flags and shale of Clarke and Luther ${ }^{10}$ ), a thick formation which in the western part of the area consists predominantly of gray and black shale. Interbedded with the shale, however, are a considerable number of thin flagstone units and at even smaller intervals are many thin regular flagstone layers. In part of that area Pepper also used four other sandstone units that he found in the overlying beds, the highest of which was about 200 feet above the horizon GR. These are shown on plate 2 as "stray sands." Southwestward the West Hill formation thickens, loses its black shale, and acquires many thick sandstone units. One of these sandstone units was used as a key bed in mapping parts of the Hammondsport, Corning, Watkins, and Elmira quadrangles. It is a virtually uninterrupted series of fine-grained, rather massive sandstone beds about 65 feet thick. The top of this sandstone unit is horizon W. The sandstone is overlain by hard brown, somewhat sandy shale, which is rarely well exposed and which locally contains numerous thin regular beds of sandstone. Below the thick sandstone unit shale and

${ }^{10}$ Clarke, J. M., and Luther, D. D., New York State Mus. Bull. 63, pp. 35-36, 1904. 
massive flagstone beds make up an alternating series 50 to 60 feet thick in which shale predominates. Below this series is another solid sandstone unit about 25 feet thick. Horizon W can be identified only in streams where a considerable thickness of the underlying beds is exposed.

This sandstone unit whose top is horizon $W$ and a few feet of the overlying shale are well exposed in the bed of a small stream just east of the village of Hornby in the northeast corner of the Corning quadrangle.

Like the base of the Grimes (GR) in this part of the area the key horizon $\mathrm{W}$ is not regarded as reliable enough to warrant drawing structure contours upon it at intervals less than 100 feet.

Horizons NB and NT.-The next two horizons are the base (NB) and top (NT) of the Nunda sandstone, which overlies the West Hill. Many years ago Luther ${ }^{11}$ traced this sandstone from its type locality at Nunda eastward into the Naples quadrangle and showed that it is the same sandstone as that which caps High Point, a hill $21 / 2$ miles northwest of Naples. For that reason the name Nunda is used in this report in place of High Point sandstone (discarded) which Clarke and Luther ${ }^{12}$ later used in the Canandaigua and Naples quadrangles and areas to the east. The Nunda sandstone in this area consists of a series approximately 100 feet thick of rather irregular massive bluish-gray fine-grained sandstone beds that range in thickness from less than 1 foot to about 10 feet. In most places the beds follow one another with no more than a bedding plane between them, but locally, especially in the western part of the area, they are separated by thin strata of sandy shale. Farther east the formation contains no shale, but rarely the sandstone beds are separated by thin lenses of shell fragments. The massive sandstone beds are generally quite barren of fossils except for a few finely preserved glass sponges.

The base (NB) of the Nunda is not a satisfactory key horizon because it is commonly transitional into the shale below and because it is rarely well exposed. It was used at only one place in the area, near the junction of Livingston, Ontario, and Steuben Counties. The top (NT) is much better, especially in the western part of the area, where it is overlain by the black Pipe Creek shale member of the Wiscoy sandstone. The Pipe Creek was named by Chadwick ${ }^{13}$ from its exposures in Pipe Creek Glen, West Falls, N. Y. From its type

\footnotetext{
11 Luther, D. D., Stratigraphic value of the Portage sandstones: New York State Mus. Bull. 52, pp. $616-629,1902$.

12 Clarke, J. M., and Luther, D. D., Stratigraphic and paleontologic map of the Canandaigua and Naples quadrangles: New York State Mus. Bull. 63, pp. 37-38, 1904.

${ }^{13}$ Chadwick, G. H., Great Catskill delta and revision of late Devonic succession: Pan-Am. Geologist, vol. 60, p. 276, 1933.
} 
locality, which is about 15 miles southeast of Buffalo, Chadwick traced it eastward into this area. Southeastward from the Nunda quadrangle it becomes sandy and changes from black to brown, and thin sandstone layers come into it. A little west of the center of the Hornell quadrangle it loses its identity and merges into the Wiscoy sandstone. But still farther southeastward, in the southern part of the Corning quadrangle, the Pipe Creek reappears as a soft dark-gray shale unit that is almost black in the extreme southern part of the quadrangle, as along Morgan Creek. Northward it becomes lighter gray and progressively more sandy until in a small ravine $1 \frac{1}{2}$ miles southwest of Presho it is hardly separable from the sandstone beds above and below it. This southeastward facies of the Pipe Creek is 30 feet thick on Morgan Creek, and a few miles farther east in Steamtown Creek it is nearly 75 feet thick. This greater thickness, however, is exceptional and includes a flagstone unit 5 to 8 feet thick about 15 feet above the base.

Horizon PT.-Although in the western part of the area the contact between the Pipe Creek and the underlying Nunda sandstone was used as a key horizon (NT), it is not so well exposed in the southern part of the Corning quadrangle as the top of the Pipe Creek. Consequently the top of the Pipe Creek shale member of the Wiscoy sandstone was used as a key horizon in this part of the area, as is indicated on plate 2 by the symbol PT.

The Wiscoy in the northwestern part of the area consists of rather soft greenish-gray muddy sandstone and sandy shale. This distinctive greenish-gray color persists for many miles to the west and also persists southeastward about halfway across this area. In the Woodhull and Corning quadrangles some of the characteristic greenish color is even stronger green in the muddier beds of the Wiscoy, whereas the harder sandstone beds have a dark-purplish tone. Like the Pipe Creek shale member, the Wiscoy becomes progressively more sandy southeastward until in the Woodhull quadrangle it is a solid sandstone formation indistinguishable from the Nunda below. Indeed, the two formations become one because the Pipe Creek shale member has in this locality also changed into sandstone indistinguishable from the Nunda. This thick succession of sandstone beds is exposed in the short, steep tributaries to the Canisteo River in the extreme southwest corner of the Bath quadrangle.

But the Wiscoy, also like the Pipe Creek, becomes softer and more shaly again still farther southeastward, in the southern part of the Corning quadrangle. In this locality the Wiscoy sandstone is somewhat thinner-bedded, softer, and muddier than farther northwestward, in the Bath and Hornell quadrangles, but it lacks the greenish color. 
Horizon WS.-At least locally in both the Corning and Woodhull quadrangles a unit of rather soft brown to gray shale 15 or 20 feet thick was found in the Wiscoy at levels ranging from 80 to 107 feet below the top. In a few places near Presho in the Corning quadrangle the base of this stray shale unit was used as a key horizon, and its position is indicated on plates 2 and 3 by the symbol WS.

Horizons $D B, D S$, and $D T$.- The base (DB) and the top (DT) of the Dunkirk sandstone and the base of a local black shale tongue (DS) were used as key horizons. The Dunkirk, which overlies the Wiscoy, has its type locality at Dunkirk, on Lake Erie, where it is all jet-black shale. It was named by Clarke ${ }^{14}$ and traced by Chadwick eastward across the State into this area. In that tracing Chadwick observed that successive sandstone tongues come into the shale and from the Genesee River eastward the formation changes rather rapidly into one consisting predominantly of sandstone. In the vicinity of Canaseraga he at first ${ }^{15}$ called this sandstone formation the Canaseraga sandstone, but now, having found that it is a sandy facies of the Dunkirk, he recommends ${ }^{16}$ dropping the name Canaseraga. Accordingly, in the area described in this report the formation is called the Dunkirk sandstone.

At the base of the Dunkirk is a unit of jet-black shale that thins progressively southeastward across the area and disappears in the northwest corner of the Woodhull quadrangle. Overlying the black shale is a unit of blue-gray flaky shale that also thins southeastward to a thin sandy shale stratum in the center of the Woodhull quadrangle and then thickens again southward and southeastward, so that at its extreme southeastern exposure in the Woodhull quadrangle it is about 30 feet thick. But all across the area except where the basal shale is thinnest the contact between the shale and the underlying Wiscoy sandstone is sharply defined and is the key horizon DB.

From the southern part of the Nunda quadrangle southeastward into the southern part of the Hornell quadrangle the Dunkirk sandstone contains several shale tongues, especially in its lower half. One of these, 110 feet above horizon DB, has black shale at the base that grades upward into bluish-gray shale, which in turn grades upward into sandstone - a sequence closely similar to that at the base of the formation but distinguishable from it by being thinner. The base of this second black shale was used locally in the Bath, Woodhull, and Corning quadrangles.

\footnotetext{
14 Clarke, J. M., Classification of the New York series of geologic formations: New York State Mus. Handbk. 19, p. 24, 1903.

15 Chadwick, G. H., Chemung stratigraphy in western New York [abstract]: Geol. Soc. America Bull., vol. 34, p. 69, 1923; The stratigraphy of the Chemung group in western New York: New York State Mus. Bull. 251, p. 150, 1924.

16 Personal communication, 1934.
} 
Southeastward from the vicinity of Hornell these shale tongues in the Dunkirk change laterally into sandstone, and in most of the rest of the area the Dunkirk is a solid sandstone unit. This sandstone is unevenly bedded or massive and bluish gray, hard, medium- or finegrained, and generally argillaceous. In general the Dunkirk sandstone is only moderately fossiliferous, but it contains many irregular lenses that are extremely fossiliferous. In the southeastern part of the Woodhull quadrangle and eastward into the southern part of the Corning quadrangle both the upper part and the basal part of the Dunkirk become somewhat shaly again.

Overlying the Dunkirk sandstone is the soft bluish-gray to brown Gowanda shale. The contact at the top of the Dunkirk is sharply defined in the greater part of the area and is horizon DT. In a considerable part of the area the contact D'T is expressed by a welldefined topographic bench where the soft shale has receded from the top of the steep slope made by the Dunkirk sandstone. (See pl. $4, A$.) Where the slopes above the bench are not timbered they are commonly scarred by small gullies that reveal the light-brown clayey soil derived from the shale. These topographic features were used as an aid in mapping, but the altitudes of the key horizon DT were measured on rock outcrops. This horizon was mapped from the northeastern part of the Canaseraga quadrangle southeastward to the Pennsylvania line in the Corning quadrangle.

Horizon DB is excellently exposed in a smail ravine on the west side of the Canisteo River, 1.2 miles south by east from the railroad bridge over the Canisteo River in the southern part of Hornell. Horizon DT is well exposed in the bed of a small stream (Jefferson Creek) 3.9 miles south of the north line of the Greenwood quadrangle and 2.3 miles west of the east line.

Horizons $G M, G A, G B, G C$, and $G D$.-Above the Dunkirk sandstone in the southwestern part of the area is a unit of soft bluishgray shale that in the lower 190 feet contains no sandstone other than a very few thin lenticular layers. Above that part sandstone beds become increasingly numerous until sandstone predominates. Certainly a large part and probably all the shaly 190 feet of beds overlying the Dunkirk may be correlated with the Gowanda beds, which Chadwick ${ }^{17}$ named from their exposures at the village of Gowanda, on Cattaraugus Creek, 30 miles south of Buffalo. Chadwick traced this shale unit, together with the underlying Dunkirk, eastward from the type locality into the area considered in this report, but the formations which he used to limit the top of the Gowanda farther

\footnotetext{
${ }^{17}$ Chhadwick, G. H., Portage stratigraphy in western New York: Geol. Soc. America Bull., vol. 30, p. 157, 1919.
} 
west are not certainly identifiable in this area. Moreover, because the gradation upward from the shale into predominantly sandy beds in this area is so gradual and because so many of the sandstone beds are lenticular, the separation of lithologic units of formation rank seemed too subjective to serve any useful purpose. The whole series of beds, therefore, from the top of the Dunkirk to the highest beds mapped in this area-more than 1,000 feet higher-are grouped as Gowanda shale and overlying beds undifferentiated. However, the various key beds within this thick series serve to show the structure of the exposed rocks and also the stratigraphic relations of the higher beds to the underlying Dunkirk.

Eastward across the area the shale in the lower 190 feet of these beds becomes brown and silty and sandstone beds come into it at successively lower levels. The lithology of the sandstones changes eastward also. In the western part of the area they are rather regularly bedded buff fine- to medium-grained sandstones, most of which are abundantly fossiliferous. Eastward they lose the fossils and become thicker, cross-bedded, and rusty brown. The shale immediately beneath some of them becomes an intimate mixture of near-shore and continental deposits.

In the southern part of the Hornell quadrangle and the northern. part of the Greenwood quadrangle, in the vicinity of Canisteo, the basal part of the Gowanda shale is abnormally sandy. This sandy phase of the lower Gowanda is well exposed in a small steep gully on the east side of Bennett Creek in the Greenwood quadrangle 0.65 mile south of the north line of the quadrangle. At that place the lower 75 feet of the Gowanda consists of gray sandy shale interbedded with numerous thin layers of sandstone. Upward the sandy part grades into the normal soft bluish-gray shale. This peculiar sandy facies of the Gowanda thins out rapidly in all directions from a maximum. near Canisteo.

The lowest key bed in the series of rocks above the Dunkirk is a lens of massive barren buff medium-grained sandstone that ranges in thickness from a few inches to about 3 feet. Its base is horizon GM. It is 162 feet above the top of the Dunkirk and is well exposed near the mouth of Rock Creek, in the Greenwood quadrangle 11/2 miles north of the village of Greenwood. This key bed was used only in the vicinity of Greenwood and apparently thins out northward and eastward.

Because the rocks in this part of the stratigraphic column in this part of the State are not generally well known and because they were exceptionally well exposed in the summer of 1935 after the floods, the following two detailed sections are included in this report. The first. 
one shows the relations of the key horizons GA, GB, and GC to the Dunkirk, and the other shows a representative section of the beds from the horizon GC upward nearly to a much higher key horizon (UC).

Section of the upper part of the Dunkirk sandstone and the Gowanda shale and overlying beds undifferentiated, in a steep ravine on the east side of Bennett Oreek 2.3 miles south of the north line of the Greenwood quadrangle

[Measured by plane table by Charles E. Fralich]

Gowanda shale and overlying beds undifferentiated:

Sandstone, thin-bedded, platy, greenish gray

Ft. in

Shale, greenish gray, flaky

2

Sandstone, cross-bedded; contains few fossils

Shale, greenish gray, soft, flaky

Sandstone, hard, massive, gray

Shale, greenish gray

Sandstone, shaly, gray, soft

Concealed

Sandstone, massive, dense, gray

Shale, greenish gray

Sandstone, dense, gray

Shale, greenish gray

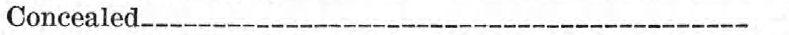

Shale, greenish gray, sparsely fossiliferous___-_-_-_-_ 4

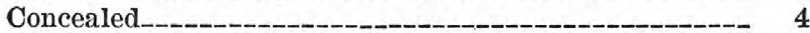

Sandstone, gray, sparsely fossiliferous_____-__-_-_ 2

Shale, greenish gray, silty_-_______-_-_ 9

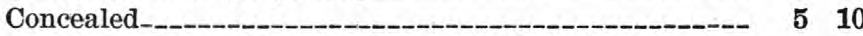

Sandstone, gray buff, massive to medium thick-bedded, limy and abundantly fossilferous__________- 3

Sandstone, thick-bedded, gray to buff, sparsely fossiliferous, becoming increasingly fossiliferous upward (horizon GO at base; altitude 1,771 feet)

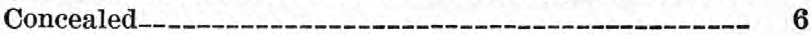

Sandstone, cross-bedded, sparsely fossiliferous__._._. 2

Concealed_-___-_-_-_ 9

Sandstone, massive, barren

Shale, gray_____-_._- 7

Sandstone, buff, medium-grained, limy, abundantly fossiliferous

Sandstone, massive, light gray; many crinoid stems in basal part________ 1

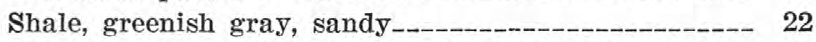

Concealed_-_-_. 3

Sandstone, gray, sparsely fossiliferous___-__-_-_-_ $\quad 1 \quad 8$

Shale, greenish gray, somewhat sandy_-_-_-_-_-_-- $18 \quad 8$

Sandstone, gray, moderately fossiliferous_______-_._. 1

Shale, gray, platy and sandy, with a few thin sandstone layers 
Section of the upper part of the Dunkirk sandstone, etc.-Continued

Gowanda shale and overlying beds undifferentiated-Con.

Sandstone, gray buff, thick-bedded, moderately fossiliferous

Ft. in.

Shale, gray

22

Sandstone, dense, gray

Shale, light gray, sandy

15

Sandstone, fossiliferous

Shale, gray.

2

$4 \quad 3$

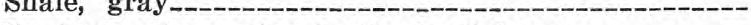

Sandstone, limy, abundantly fossiliferous_._._-_.-_-

Shale, gray -..._-

Sandstone, buff, limy, extremely fossiliferous_-_-_----

Shale, gray, moderately fossiliferous
Sandstone, thin, rather regularly bedded, moderately fossiliferous

Shale, gray

Sandstone, gray buff, abundantly fossiliferous_--.---

Shale, gray-

Shale, hard, sandy, extremely fossiliferous_......-.-.

Shale, gray_-_-_-_-_-_-_-_-

Sandstone, buff, medium-grained, massive, cleanly sorted, moderately fossiliferous (horizon GB at base; altitude 1,640 feet)

Shale, bluish gray, becoming lighter gray and sandy in upper part.-.--

Sandstone, shaly, abundantly fossiliferous_._-_-_-_-_-

Shale, gray

Sandstone, thin-bedded, alternate layers fossiliferous and barren

Shale, gray

Sandstone, limy, abundantly fossiliferous_-_-_-_-_-_--

Shale, gray

Sandstone, dense, gray-_-__-__-_-_

Shale, gray

Sandstone, dense, gray-_-_-_-_

Shale, gray-_-_-

Sandstone, dense, gray-_._-_._-

Shale, gray

Sandstone, thin-bedded, platy, gray buff_-_._-_.-_-_

Shale, gray_-___-_.

Sandstone, shaly, abundantly fossiliferous_...-..-.--

Shale, gray-_._-_-_-_-_-

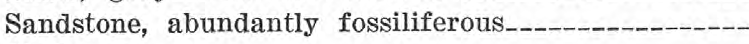

Shale, gray

Sandstone, abundantly fossiliferous_._._._._-_._-_-_-_

Shale, gray

Sandstone, thin-bedded, sparsely fossiliferous_._.-.-.-

Shale, drab to gray__-_______-_-

Sandstone, gray buff, very fossiliferous___-_-_-_-_-_-_

Shale, gray-_-

Sandstone, liver-colored, massive, even-grained, cleanly sorted, moderately fossiliferous (horizon GA at base; altitude 1,559 feet) 
Section of the upper part of the Dunkirk sandstone, etc.-Continued

Gowanda shale and overlying beds undifferentiated-Con. Ft. in.

Shale, bluish gray, soft, fissile___________-_ 5

Concealed _._. 11

Shale, bluish gray_-_-_-_-_ 25

Concealed___-

Shale, bluish gray___- 5

Concealed_-_- 7

Shale, bluish gray_-_-_- 2

Concealed_-_.

Shale, bluish gray

Concealed._-_- 20

Sandstone, dense, gray

Shale, soft, bluish gray, homogeneous, sparsely fossil-

iferous; lower 28 feet sandy_-___-_-_-_-_-_-_ 112

Concealed__-_-

Total thickness of exposed portion of Gowanda and overlying beds____._-_._. 488

Dunkirk sandstone:

Sandstone, bluish gray, medium-grained, massive, unfossiliferous (horizon DT at top)

Sandstone, gray, medium-grained, massive irregular beds or obscurely cross-bedded, sparsely to profusely fossiliferous

Sandstone, gray, unfossiliferous _______-_-_._- 1

Sandstone, bluish gray, massive to cross-bedded, sparsely fossiliferous, with thin abundantly fossiliferous lenses____-_-_-_ 13

Sandstone, unfossiliferous___________-__-_ 3

Sandstone, gray, irregularly bedded, sparsely fossiliferous_-_-_-_-_-_-_-_-_- 11

Sandstone, unfossiliferous______-_-_-_-_ 2

Sandstone, gray, irregularly bedded to obscurely crossbedded, sparsely fossiliferous

Concealed to creek level.

Total thickness of Dunkirk exposed

Section in the Gowanda and overlying beds undifferentiated from key horizon $G C$ nearly up to key horizon $U C$, in a trench washed in the north side of the steep road that leads up westward from the village of Greenwood to Dryden Hill School

[Measured by W. H. Bradley by hand leveling]

Shale, not well exposed.

Sandstone, light greenish gray, hard, highly cross-bedded; somewhat more muddy at top_____._. 5

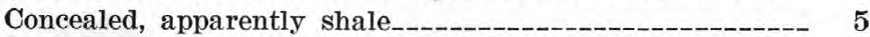

Sandstone, light gray, hard, platy, rather regularly thinbedded; interbedded with thin shale layers in lower part

Ft. In. 5 
Section in the Gowanda and overlying beds, etc.-Continued

Shale, greenish gray, soft, with a few widely spaced thin Ft. in. sandstone layers__-__-_-_-_ 15

Shale, alternating with about an equal amount of thin sandstone layers

Shale, greenish-gray, soft

Sandstone, gray, hard, massive, with mud lumps

Sandstone, dark brown, strongly stained with iron oxide; contains pebbles as much as 1 inch across_

Shale, greenish gray, soft, clayey

Sandstone, chocolate-brown to dull reddish, hard, platy to gently cross-bedded, with thicker massive beds; upper and lower parts grayish (altitude at top 2,050 feet) -.----

Shale, greenish gray, micaceous, soft

Sandstone, greenish-gray, ripple-bedded to lumpy; many worm trails

Shale, greenish gray, soft, sandy at base and grading upward to nearly pure clay

Sandstone, greenish gray, platy, with many rusty mud lumps and crinoid stems.

Sandstone, drab, muddy, lumpy

Sandstone, brown, hard, platy

Concealed, apparently shale

Sandstone, gray, muddy, grading upward into flaky shale_-

Sandstone, light gray, hard, platy, cross-bedded; interbedded with larger amount of drab soft lumpy sandstone, but the top 6 to 8 feet is well sorted light-gray, highly cross-bedded sandstone.

Sandstone, muddy, soft, thin-bedded

Sandstone, light gray, hard, platy, cross-bedded, micaceous

Concealed.

Sandstone, dark brown, deeply stained with iron oxide, soft, muddy; grades up into hard sandy shale_._-_.-- 5

Shale, poorly exposed._-_. 10

Sandstone, drab, muddy, irregularly bedded___._....... 1

Shale, soft, flaky

Sandstone, gray, hard, massive

Concealed, apparently shale

Sandstone, reddish brown, platy

Concealed, considerable sandstone float_-_._-_-_-_-_-_--.

Sandstone, gray, platy and shaly at base but grades upward into harder brownish-maroon cross-bedded sandstone (altitude at top 1,905 feet)

Shale, gray

Sandstone, gray, with worm borings___-_-_-_-_-_-_-

Shale, gray, with few thin sandstone layers, but becoming more sandy toward top

Sandstone, brown, regularly bedded, extremely fossiliferous

Shale, gray, soft

Sandstone, gray, hard, regularly bedded; base fossiliferous, rest barren 
Section in the Gowanda and overlying beds, etc.-Continued

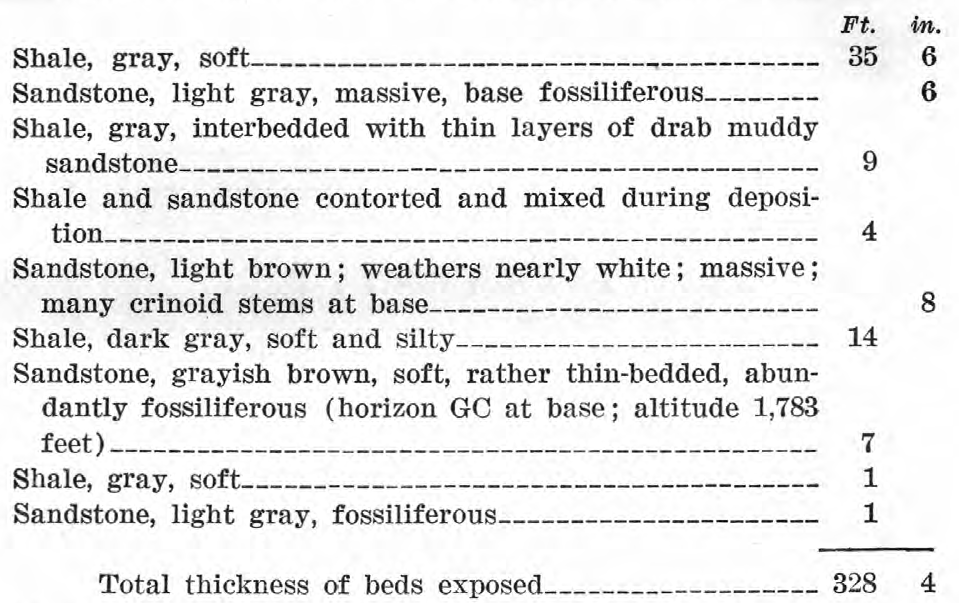

In the first section given above, the key horizons GA, GB, and GC are persistent except along parts of Slate and Purdy Creeks in the Greenwood quadrangle, where the beds at this general stratigraphic level were much disturbed by faulting and submarine sliding at the time they were being deposited. The beds between the key beds are somewhat variable in thickness and lithology. Higher in the stratigraphic section the variability is even greater, as is illustrated by the fact that the sandstone's shown in the section measured on the hill west of Greenwood (pp. 22-23) thin southwestward and in a branch. of Christian Hollow about 2 miles S. $30^{\circ} \mathrm{W}$. are replaced in large part by soft gray shale indistinguishable from that in the lower part of the Gowanda. At other places in the Greenwood quadrangle the beds above the key horizon GC are predominantly sandstone. But even apart from these extremes, fairly well exposed sections of these higher beds measured in successive adjacent stream valleys have so little in common that they could not be correlated.

Horizons GA, GB, and GC have not been traced eastward across the Greenwood quadrangle, but the bed whose base is horizon GA apparently represented by 13 feet of muddy brown to drab unfossi. iferous sandstone in a section measured in the northwestern part of the Woodhull quadrangle. In the western part of the Woodhull quadrangle Pepper discovered sandstone beds which correspond approximately in their intervals above the Dunkirk with beds whose bases are horizons GB and GC. For convenience, and to indicate at least approximate and perhaps real equivalence, the bases of these sandstones are also designated GB and GC, despite the fact that these beds differ in lithology from those in the western part of the Greenwood quadrangle whose bases are designated GB and GC. Instead 
of being fossiliferous, somewhat limy sandstone they are dark-brown muddy, highly cross-bedded sandstones, each about 20 feet thick and each characterized by a conspicuous bed of red sandy shale immediately below. The red shale is one of the principal distinguishing characteristics and crops out only in roads and road cuts. These two similar beds are particularly useful in mapping interstream areas where outcrops are rare. They were used as key beds over considerable areas in the Woodhull and Corning quadrangles. They were also traced a little way westward into the Greenwood quadrangle, but in that direction the lithology changes rather rapidly and they lose their distinguishing characteristics. The red shale changes to brown or grayish shale and the sandstone beds thin and become gray and more massive. Locally, in the vicinity of Troupsburg. (Greenwood quadrangle), a spring zone at horizon GC was mapped.

Horizon GB is well exposed in a road cut 2.4 miles north of the south line of the Woodhull quadrangle and 0.43 mile east of the west line. Horizon GC is well exposed in a road cut 0.87 mile west of the east line of the Greenwood quadrangle and 3.5 miles north of the south line. It is also excellently exposed in a steep road 3 miles west of the east line of the Woodhull quadrangle and 2 miles north of the south line.

Horizon GD.-Key horizon GD is the base of a sandstone bed that is much like the beds whose bases are respectively horizons GB and GC in the Woodhull quadrangle and vicinity but differs in having a much thicker zone of red shale below. This horizon was used at only two places in the Greenwood quadrangle and one in the Woodhull quadrangle. An exposure of this horizon is easily accessible on a recently graded road 0.2 mile east of the west line of the Woodhull quadrangle and 5.85 miles south of the north line.

Horizons $U C$ and $U U$.- In the southeastern part of the Wellsville quadrangle and the southwestern part of the Greenwood quadrangle the highest beds mapped in the area are exposed, and in these beds are the two key horizons UC and UU. UC is the lower of the two and was used over a somewhat larger area. It is fairly well exposed in a steep road on the south side but near the top of a hill 2.4 miles north of the south line of the Greenwood quadrangle and 5.4 miles west of the east line, where the following section was measured:

Section on hill in southern part of Greenwood quadrangle

Sandstone, light gray, almost white, cleanly sorted, medium- Feet to coarse-grained, platy and highly cross-bedded

Shale, bright red, sandy (horizon UC at base; altitude 2,195 feet)

Sandstone, massive, highly distinctive pistachio-green sandstone that has a sugary texture. 
Section on hill in southern part of Greenwood quadrangle-Continued

Sandstone, sugary-textured, light greenish gray mottled with dull red, massive; in beds 1 to 3 feet thick that alternate with red sandy shale or massive dull-red muddy sandstone_ Shale, reddish, sandy; unit contains some massive brown muddy sandstone; not well exposed

Feet

20

48

5

The beds above and below horizon UC are somewhat variable along the strike, but the massive pistachio-green sandstone and overlying bright-red sandy shale, which in turn is overlain by the unit of hard, nearly white highly cross-bedded sandstone, are all persistent. This key horizon (UC) has thus far been recognized only in roads and road cuts.

The beds used to define horizon UU, which is 130 feet higher than UC, are closely similar to those used to define horizon UC. At the top of the group of beds is a series of light-gray hard, highly crossbedded sandstone of variable thickness but generally about 20 feet, below which is about 5 feet of massive pale-green sandstone in indefinite layers 6 to 12 inches thick. This greenish sandstone is underlain by bright-red sandy shale 2 to 4 feet thick, which grades downward into gray muddy sandstone about 5 feet thick. Below this is another highly cross-bedded light-gray sandstone unit 10 or 12 feet thick. The presence of this second cross-bedded sandstone below the red shale is the principal means, other than stratigraphic relations, of distinguishing horizon UU from UC. Locally, however, the upper cross-bedded sandstone of this group is overlain by a series of rather thick beds of massive light-buff sugary-textured sandstone. The contact between the red shale and the pale-green sandstone was used as the key horizon UU. This key horizon, with the overlying and underlying beds, is fairly well exposed in the road just west of the Dryden Hill School, 2.95 miles east of the west line of the Greenwood quadrangle and 8.3 miles south of the north line. Like horizon UC, it has thus far been identified only in roads or road cuts.

Locally the base or top of one or another of the red shale bands or sandstone beds between these two horizons was used for structural control, and where these are shown on plate 2 they are referred to as "stray sands."

\section{SUBSURFACE STRATIGRAPHY}

Because the rocks in this area dip generally southward and southwestward the formations that are exposed in the northeastern part of the area pass southwestward beneath a progressively thicker cover of higher formations. Each formation, with the exception of the highest beds in the sequence, might therefore appropriately be treated as an element of the subsurface stratigraphy in a large part of the 
area. But in this report only those formations that are readily identifiable in drill cuttings will be considered under the heading of subsurface stratigraphy. Only a few formations come into this category.

The highest of these is the Dunkirk sandstone, whose thick hard sandstone beds should be readily identifiable after having passed through nearly 200 feet of soft bluish-gray shale of the overlying Gowanda. The use of the Dunkirk as a subsurface stratum, however, would be restricted to the southwestern part of the area in the Canaseraga, Wellsville, and Greenwood quadrangles and perhaps also parts of the Woodhull quadrangle.

The most extensive and most useful subsurface unit is the Tully limestone, which is present throughout the area except a comparatively small section in the northwestern part. Southward from its outcrop the Tully thickens gradually and along the Pennsylvania line ranges between 25 and 45 feet in thickness. It is almost ideally suited for identification in well cuttings, because it is the only limestone of comparable thickness in the whole section that is both overlain and underlain by hundreds of feet of soft shale. Moreover, because the Tully is hard and brittle and is set in a thick body of shale, it is equally well suited for a reflecting bed in seismograph surveys. Furthermore, structural features determined on the Tully commonly reflect closely similar structural features in the Oriskany below. Departures from strict similarity of structure in these two formations are to be expected, however, especially in the southeastern part of the area, where the shale of the Hamilton group between them becomes sandy and thickens rather rapidly. Other departures are to be expected in parts of the area that are faulted, because the soft shale between the Tully and the Oriskany takes up the displacement of faults. Thus small faults in the Tully generally increase downward and may become highly significant structural features at the horizon of the Oriskany. For example, drilling in the State Line gas field, in the southwest corner of the Wellsville quadrangle showed no displacement whatever at the Tully level but nearly 200 feet of displacement in the Oriskany directly below.

The next formation below the Tully that is likely to be identified from drill cuttings is the jet-black Marcellus shale, the lowest formation of the Hamilton group. It is about 50 feet thick. In drill cuttings the particles of jet-black shale have a powdery surface and appear dark brown.

Immediately below the Marcellus is the Onondaga limestone. This thick hard cherty light bluish-gray limestone underlies the entire area. Though extensive, it is variable in thickness, which ranges, apparently unsystematically and within comparatively short distances, from less than 50 to more than 100 feet. Part of this varia- 
bility, however, may be more apparent than real, owing to the fact that at the top the limestone grades into the overlying shale, thus making the top of the Onondaga proper difficult to identify certainly in drill cuttings.

Below the Onondaga is the Oriskany sandstone, the principal gasproducing bed of this region. It is a light-gray to nearly white, cleanly sorted medium- to coarse-grained massive quartz sandstone. In general it thickens southward, but in detail it is variable in thickness and may be absent or as much as 60 feet or more. With the subsurface data available no systematic variation has yet been determined that will assist in predicting where it will be present or absent. In the northwestern part of the area, according to available records, the Oriskany is absent. ${ }^{18}$

Further details on the subsurface stratigraphy of this area and a large part of western New York will be found in Richardson's report.

\section{STRUCTURE}

\section{METHODS OF REPRESENTING STRUCTURE}

The structure of this area is shown by the structure contour map (pl. 2), which represents the attitude and displacement of the strata by means of lines of equal altitude above sea level on the base of the Rhinestreet shale in the northern and eastern part of the area and on the base of the Dunkirk sandstone in the southwestern part of the area. Two different horizons were chosen to represent the structure because the regional southwesterly dip carries the Rhinestreet shale deep under cover in the southwestern part of the area, where too little is known about the intervals between the Rhinestreet and the surface rocks to make contours on the Rhinestreet as significant as those drawn on a key bed much nearer the surface.

In areas where these key beds lie beneath younger formations, the map represents the subsurface structural configuration of the key beds as inferred from the visible deformation of the overlying beds exposed at the surface. In areas where formations stratigraphically below these key beds are exposed the map represents the inferred attitude of the key beds before they were removed by erosion.

No angular unconformities of regional extent are known between any two of the formations exposed in this area, but all the formations, except the few thin limestone beds, thicken progressively southeastward. This thickening is shown graphically in figure 4 and was duly allowed for in the construction of the structure contour map. An unusual sort of discordance between some of the youngest

\footnotetext{
${ }^{18}$ Richardson, G. B., Subsurface structure and convergence in part of western New York and relation of Medina gas to structure and stratigraphy: U. S. Geol. Survey Bull. 899-B [in preparation].
} 
rocks exposed in the southwestern part of the area and the underlying rocks is discussed on pages 38-42.

The structure contours are based on the instrumentally determined altitudes of the key beds that have been described on preceding pages. The direction and spacing of the contour lines were controlled in part also by the strike and dip of the beds as observed at the surface.

The attitude of the beds is shown also in part by dip and strike symbols, and in parts of the area, where no key beds were mapped, only dip and strike symbols and a few fold axes are shown. However, in areas like this part of New York State, where the rocks are so gently inclined, dip and strike observations give only a qualitative impression of the structure, of reconnaissance value only.

\section{GENERAL FEATURES}

In the northwestern part of the area the rocks dip gently southward, but in the greater part of the area they dip generally toward the southwest. In considering the regional inclination of the rocks one other feature of regional size is discernible-a sort of structural plateau in the northeastern part of the area. This somewhat vaguely defined plateau is bounded on the south by a belt of rocks that dip rather steeply southward from the crest of an east-west anticline whose axis is about 4 miles south of the south end of Seneca Lake. This belt of relatively steep dips then swings northwestward toward the middle of Keuka Lake, from which it strikes northward nearly to Penn Yan and then swings northwestward, where the dips decrease and the belt loses its identity.

\section{TREND AND FORM OF FOLDS}

Upon the regional south and southwest dip are superposed numerous gentle folds, whose arrangement is characterized more by lack of system than by any clearly defined system. Folds that are plainly traceable across the area are exceptional; most of them are rather short and almost haphazard in their arrangement. Many of the anticlines tend to fork southwestward, whereas the synclines, in a complementary manner, tend to fork northeastward. In a broad way, however, the fold axes trend approximately northeastward in the greater part of the area and more nearly eastward in the eastern part. Also the folds have a general tendency to become narrower and steeper and therefore more closely spaced southwestward.

Because of the regional dip all the folds have a predominant southwestward plunge. The local northeastward plunge of anticlinal axes, which causes the formation of closures or domes, is comparatively rare and generally of small magnitude. Usually, however, the small northeastward plunge is opposed at the other end of a dome by an 
abnormally steep southwestward plunge. In at least two places anticlinal axes of domes plunge northeastward into elongate closed synclines which are so oriented that the synclinal axes appear to be the continuations of the anticlinal axes.

\section{TREND OF FAULTS AND JOINTS}

In all parts of the area the rocks are jointed, and the joints fall into two dominant sets, one that trends northwest and the other east or northeast. Of these the northwest set is decidedly dominant. The northwestward-trending joints are usually straight, clean, open fractures, whereas the northeastward-trending joints are commonly ragged, tight, and in many places curved and relatively short. In the northeastern part of the area the two sets of joints have average trends of N. $30^{\circ} \mathrm{W}$. and N. $80^{\circ}$ E. But these average trends change gradually southwestward to N. $45^{\circ} \mathrm{W}$. and N. $60^{\circ}$ E. The extreme range of trend for both sets of joints in any part of the area, however, is nearly $30^{\circ}$. Most of the joints measured by the members of the Geological Survey party were in sandstone, flagstone, or hard silty shale, as they are more conspicuous in such rocks, whereas the joints in the softer shale are generally curved and relatively short and obscure. The joints in the brittle sandstones and sandy beds are generally almost vertical; those in the softer beds dip through a wide range of angles.

Despite the apparent regional relation to the structure no evident relation between the dominant joints and the individual folds or domes was discernible, even in the Watkins quadrangle, where the exposures are fairly good and hundreds of observations on the joints were recorded. It may be only the subordinate joints, which dip less steeply, that are related to individual folds or the pitch of their axes. ${ }^{19}$

The faults are concentrated in the northeastern and southwestern parts of the area and in each place generally trend either northeastward or northwestward, though in the northeastern part of the area several faults trend nearly due east and others trend nearly due north. Some of these faults are known from exposures to be nearly vertical normal faults and others to be rather high-angle thrust faults.

Although the faults play a significant part in the interpretation of the surface geology, they are likely to be much more significant for a proper interpretation of the subsurface geology, because subsurface data show that many of them increase in displacement as they extend downward toward the Oriskany sandstone. A consider-

\footnotetext{
${ }^{19}$ Sheldon, Pearl, Some observations and experiments on joint planes: Jour. Geology, vol, 20, pp. 72-77, 1912.
} 
able number of faults that are known to displace the Oriskany sandstone do not reach the surface but are reflected there only in a zone of abnormally steep dips. Indeed, subsurface data in the State Line gas field, in the extreme southwest corner of the area covered by this report, show that some faults displace the Oriskany nearly 200 feet but do not extend upward to or much above the Tully limestone. Hence, because faults that are evident in the surface rocks of this area, even though their displacement is small, are likely to be highly significant in depth, the groups of faults or individual faults in each of five quadrangles are discussed briefly.

\section{THE FAULTS DESCRIBED BY QUADRANGLES}

Ovid quadrangle.-In the northwestern part of the Ovid quadrangle and extending westward into the adjacent Penn Yan quadrangle is a normal fault that trends eastward and displaces the Tully limestone down on the north at least 50 feet. This fault and another of similar trend about $1 \frac{1}{2} 2$ miles farther south, on the west shore of Seneca Lake, were mapped by C. E. Fralich.

In the southeastern part of the Ovid quadrangle three faults were mapped, all of which apparently trend northeastward. The northern one of these is fairly well exposed at two places in a small stream about 1.3 miles east of Seneca Lake. At the western exposure of the fault in this stream the lower part of the Cashaqua shale is faulted down on the north against the uppermost flagstone layers in the Middlesex. The fault is apparently normal, with the beds on the downthrown side dragged up so that in places they dip $35^{\circ} \mathrm{N}$. Elsewhere near the fault, however, the dips are variable both in amount and in direction. Where the fault is exposed a little farther upstream, beds of black shale in the Cashaqua are brought down against the grayer shale near the base of the Cashaqua. The dips are steep, but the crushed zone along the fault plane is narrow. The throw at this place is estimated to be between 25 and 50 feet. This fault crosses a small syncline, as is shown by the prevailing $2^{\circ}$ southeast dip beyond the fault along the lower part of the stream and the prevailing southwest dip along the upper part of the stream. As is shown on plate 2, the trace of this fault is extended about 2 miles northeastward beyond its easternmost exposure so as to cross Mill Creek at a place where the beds dip $17^{\circ} \mathrm{N}$., although there are no exposures in the intervening area.

About a mile farther south the plane of another but smaller fault with a similar trend is exposed in the bed of a small stream. The dips show that this is a normal fault.

A plane-table traverse up Breakneck Creek, which enters Seneca Lake from the east at a point 0.4 mile south of the Seneca-Schuyler 
County boundary line), where the exposures are excellent, showed that the Rock Stream flagstone member of the Cashaqua shale had the expected thickness but that there was a little more than 400 feet of shale exposed below it, whereas elsewhere in that locality this lower shale portion of the formation is only 220 to 230 feet thick. This abnormal thickness of the Cashaqua shale led to the inference that a fault cut the beds in such a way as to duplicate much of the lower shale portion of the Cashaqua. Because no fault was observed in the valley of Breakneck Creek, the trace of the inferred fault was drawn through the only break in the exposures of shale in that part of the Cashaqua. This fault trace was extended southwestward to pass between the northern of two wells (Nos. 27 and 28, pl. 2) drilled near the lake shore and an exposure of the key horizon MF in Curry Creek (the small stream 0.7 mile south of Breakneck Creek) because the altitude of the Rhinestreet base $(R)$ as calculated from the well record (No. 27) is abnormally high with respect to the Rhinestreet altitude as calculated from the Curry Creek exposure of the key bed MF. The regularity of the beds and the prevailingly low dips along both sides of the trace suggest that it is a steep normal fault. Its throw is at least 100 feet, though the abnormal thickness of the Cashaqua suggests that it may be considerably more.

Watkins quadrangle.-The long fault roughly parallel to Seneca Lake on the east was not observed in the field. Its presence is inferred from the following evidence. Virtually all the dips from Seneca Lake eastward to the inferred trace of the fault and beyond are eastward, yet the altitudes of the key beds east of the inferred fault trace are abnormally high with respect to those of the key beds between this trace and the lake. This jump in interval is localized consistently along a line and is greater than would be expected from normal eastward thickening of the sediments. The most reasonable interpretation of these observations appears to be a fault whose downthrown side is on the west. No evidence is available to show whether the inferred fault is normal or reverse, but the displacement is estimated to be approximately 75 feet through a considerable part of its length. This fault apparently dies out northward and southward.

Nearly in line with this inferred fault is a small thrust fault that is exposed in both large tributaries to Catherine Creek about a mile southeast of Montour Falls. This fault, however, dips $12^{\circ}-40^{\circ} \mathrm{W}$. and has a displacement of about 35 feet up on the west, opposite to that of the inferred fault farther north. The rocks along this small fault are not at all crushed, although in places they dip as much as $20^{\circ}$.

About 3 miles southwest of the town of Watkins, on Glen Creek, the stream that flows through the town, two faults are well exposed 
in the south wall of the valley. The eastern one is a steep normal fault downthrown on the west side about 30 feet, as is shown by the displacement of the key horizon CF (the base of the Rock Stream flagstone member of the Cashaqua shale). The other fault is a thrust fault that dips $22^{\circ}-35^{\circ} \mathrm{W}$. Unlike those at the small thrust fault southeast of Montour Falls, the rocks along this thrust plane are intensely crushed in a zone 3 to 8 feet thick. At the outcrop the throw of this fault is not evident, but to judge from the intensity of the crushing it may well account for the apparent high position of the Rhinestreet $(\mathrm{R})$ west of the faulted zone and the correspondingly low position of the key horizon CF in the syncline east of the faults. The extension of the faults beyond their observed exposures is inferred without any supporting evidence save that the normal fault is extended about $2 \frac{1}{2}$ miles southward to pass between two outcrops of the Rhinestreet $(R)$ that appear to be offset in the same direction as the fault.

Across the southern part of the Watkins quadrangle the rocks exposed at the surface in a rather wide belt have an abnormally steep southward dip. This belt of relatively steep dips is apparently the surface expression of a subsurface fault. This opinion is based partly on the record of a well drilled in the middle of this belt (No. 46, pl. 2, which is 2.6 miles southeast of Montour Falls) and partly on analogy with similar features farther southwest in the Tioga gas field, Pennsylvania. The well record shows that the interval between the Tully and the Oriskany is about 350 feet, or approximately 30 percent thicker than the normal rate of thickening from wells a few miles distant would lead one to expect. A northward-dipping reverse fault passing anywhere between the top of the Onondaga and the Tully would explain the observed relations and moreover agrees with the interpretations ${ }^{20}$ of subsurface structure in the Tioga gas field, based upon more adequate information.

Bath quadrangle.-The only fault discovered in the Bath quadrangle is a small one about 2.5 miles east by north from the town of Bath. It trends a little north of east and is a normal fault downthrown on the south. Its throw is unknown but probably small.

Greenwood and Hornell quadrangles.-Several of the faults that cut the surface rocks in the Greenwood and Hornell quadrangles are highly significant, because they provide the evidence which leads to the belief that the rocks in this part of the State were considerably deformed in Upper Devonian time, during the interval when a portion of the Gowanda shale and overlying beds was being deposited. These faults are restricted to the northwestern part of the

${ }^{20}$ Cathcart, S. H., and Myers, T. H., Gas in Tioga County, Pa. : Pennsylvania Top. and Geol. Survey Bull. 107, p. 19, fig. 5, 1935. 
Greenwood quadrangle and the extreme southwestern part of the Hornell quadrangle. They obviously fall into two groups-those trending northwestward and those trending northeastward. Furthermore, the faults of these two groups are as divergent in characteristics and history as they are in trend.

The faults having a northwestward trend are steep normal faults that displace the surface rocks only a few tens of feet at most, and the rocks even closely adjacent to the fault planes are only slightly warped or fractured. These faults are much younger than those of the other set and appear to have resulted from tensional stresses that acted in a northeast-southwest direction subsequent to Upper Devonian time. That they resulted from tensional stress is suggested by the small graben about $2 \frac{1}{2}$ miles north of the village of Greenwood. Although the surface rocks are displaced only about 25 feet or less, the faults evidently increase in throw downward, as is indicated by the relative altitudes of the Tully and Oriskany in the well drilled in the graben (No. 6, fig. 6, p. 50) and in the nearest well (No. 5, fig. 6), approximately 2,400 feet west by north. Both wells pass through rocks at the surface that are within a very few feet of stratigraphic equivalence, but in depth the stratigraphic intervals in the graben well (No. 6) thicken so that the Tully is 42 feet lower and the Oriskany 84 feet lower than in the other well (No. 5). The well in the graben struck salt water, whereas the other well had an initial open flow rated at 50 million cubic feet of gas a day.

The other fault belonging to this group of northwestward trend is a few miles northeast of the small graben just described. It is exposed high in the valley of a small stream about midway between Slate and Fall Creeks, where it displaces the beds between horizons GB and GC a little more than 25 feet. The beds on the upthrown side are bent down into the fault, but those on the downthrown side are not appreciably deformed. This fault apparently extends southeastward and cuts the highest beds exposed in a small gulch about half a milè north of Slate Creek, where the beds dip about $36^{\circ} \mathrm{NW}$.

The faults of the group that trend northeastward differ from those of the group just described chiefly in having generally wide belts of highly deformed beds on both sides of the fault plane. These highly deformed beds, however, are restricted to a stratigraphic zone a few hundred feet thick in the Gowanda shale and overlying beds. In most places the lowest beds included in these highly deformed zones are 100 feet or more above the base of the Gowanda shale.

On Slate Creek 4 miles north of the village of Greenwood the deformed zone begins in the south bank of the stream opposite the first large tributary that enters from the north. At that place the 
key horizon GA and the associated beds are gently warped and cut by small faults. Upstream on Slate Creek this key bed, together with the overlying beds, are folded into progressively larger and steeper folds. Most of these folds trend northeastward, though a few, especially those farthest east, trend more nearly eastward. They are broken by both steep- and low-angle reverse and normal faults, none of which exceed a few tens of feet in displacement. Evidence that these beds were deformed before they had hardened into rock becomes increasingly apparent as they are traced upstream. Sandstone beds overlain and underlain by relatively thick units of soft shale behaved locally like quicksand under the deforming stress. On the upthrown sides of normal faults these beds thinned to mere ribbons, whereas near reverse and lower-angle thrust faults, where they were compressed, they swelled in irregular bulges to several times their normal thickness. Common also are small, sharp folds in these now hard and brittle sandstone beds. Moreover, the crests of most of these small folds are broken by steplike series of microfaults, though the beds themselves are perfectly massive and appear to have been bent while plastic. The significance of these microfaults is discussed more fully on pages $39-41$.

In the vicinity of the Slate Creek fault, whose plane is not certainly identifiable, the beds are either vertical or nearly so and strike $\mathbf{N}$. $35^{\circ}-40^{\circ} \mathrm{E}$. In this steeply dipping series at least one isoclinal fold was found. In this zone where the rocks have been most compressed much of the soft shale has a fairly well defined, nearly vertical slaty cleavage that strikes nearly parallel to the fault. Elsewhere along the creek the shale, even though intricately contorted, shows no such metamorphism, apparently because it was deformed soon after it was deposited and while it was still wet and plastic. The slaty cleavage in the shale near the fault trace therefore indicates that this fault was active not only during the Upper Devonian time while these beds were being laid down, but also again much later, after they had been thoroughly indurated and uplifted.

Upstream from the fault it is impossible to trace individual beds, because they are so highly contorted and so variable in lithology. The sandstone beds are thinned and pulled apart or greatly thickened. Locally masses of sandstone that have been twisted into cruller-shaped lumps are isolated in the shale. (See fig. 1.) Also larger parts of nearly undeformed beds are isolated in the shale. Locally rather large masses of shale, sandstone, and coquina layers are all stirred together, so that the rock looks like a banded gneiss. Such masses must have been fluid when deformed, for in some places only a few feet away these three constituents make up regular layers and thin beds, though they are considerably twisted and 
warped. Still farther upstream the deformation is less intense. As exposed along Slate Creek the deformed zone is at least $11 / 2$ miles wide, measured at right angles to the general trend of the minor folds.

In the first large tributary to Slate Creek that enters from the north the same beds that are deformed on Slate Creek are folded and faulted in a comparable manner. Apparently the fault that crosses Slate Creek continues northeastward and crosses the two branches of this tributary. In the western branch the beds are considerably deformed and faulted for a distance of about 0.4 mile upstream from the junction of the two branches. Still farther upstream, however, the beds are essentially undisturbed. Because these

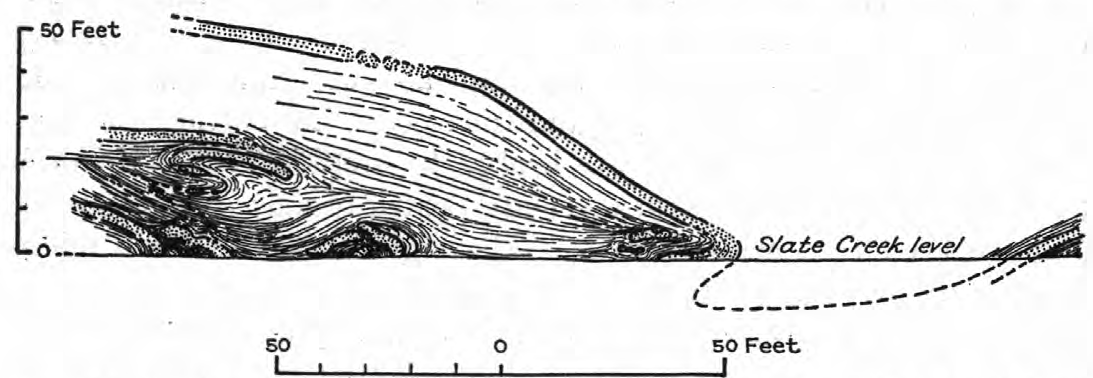

FigURe 1.-Sketch showing a portion of the shale and sandstone zone, in the south bank of Slate Creek, that was deformed soon after deposition. The sandstone beds were drawn out, twisted, and pulled apart while they were still wet uncemented sand layers embedded in slightly compacted mud.

undisturbed beds seem clearly to belong to stratigraphic levels well above those in the contorted zone it appears that the upstream or northwestern side of the Slate Creek fault is downthrown. This inference is confirmed also by the apparent differences in stratigraphic level of the rocks on the two sides of the fault on Slate Creek itself, though the evidence there is less convincing.

Two faults in many respects similar to the Slate Creek fault were observed in the valley of Purdy Creek and its tributaries. Purdy Creek rises in the northwestern part of the Greenwood quadrangle. and flows northeastward into the southern part of the Hornell quadrangle. In two of the northward-flowing tributaries which enter the main Purdy Creek half a mile and 1 mile southwest of the place where the creek crosses the quadrangle boundary, the beds in the Gowanda shale and overlying beds are folded, faulted, and intricately contorted. These deformed beds differ from those along Slate Creek and its tributaries in but few particulars, the most notable of which is the apparent settling of a thick sandstone bed into a crack or minor graben 30 to 40 feet across while the beds were still soft. 


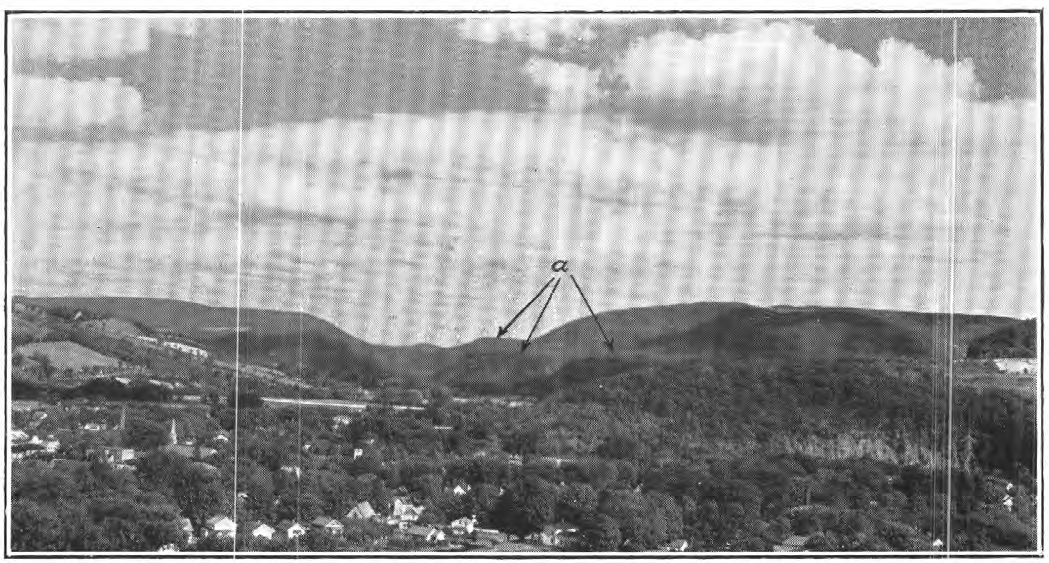

A. VIEW SOUTHEASTWARD DOWN THE CANISTEO RIVER OVERLOOKING THE TOWN OF CANISTEO.

Shows at $a$ the bench at the top of the Dunkirk sandstone and, rising from the bench, the slope made by the Gowanda shale and overlying beds.

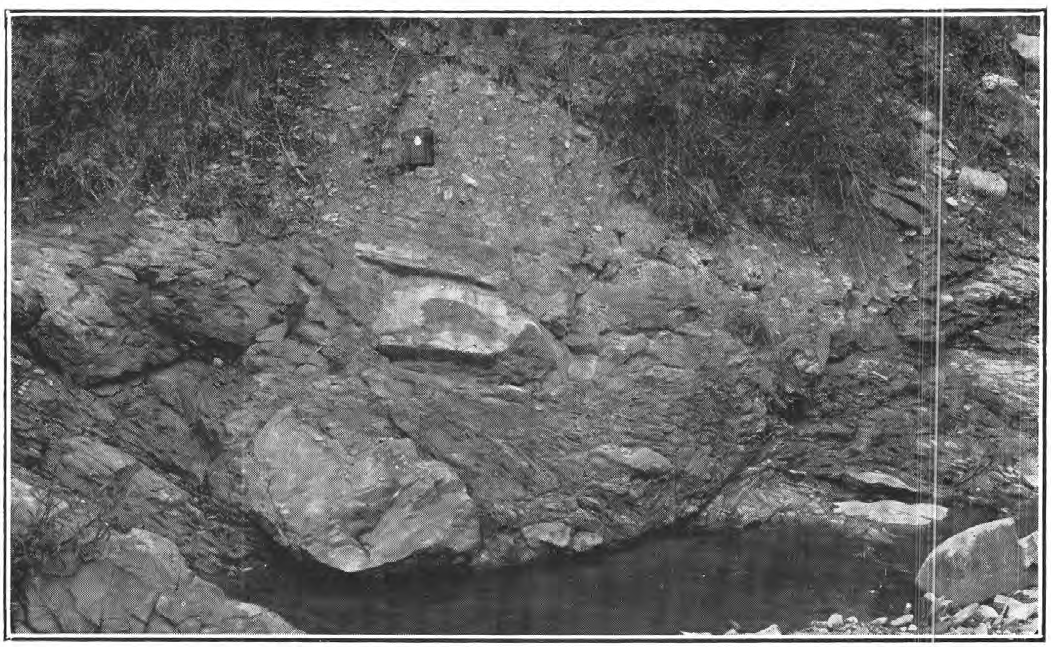

B. DETAIL OF THE PLASTICALLY DEFORMED SEDIMENTS IN THE FAULT ZONE ON PURDY CREEK.

Shows the molded sandstone masses in a matrix of contorted shale. The sandstone block at the water level is a little more than 4 feet long. 

The sandstone layer there forms a deep U-shaped mass with vertical limbs, and the shale underlying it is highly contorted and filled with rounded masses of muddy sandstone. Elsewhere the sand, originally deposited in layers several feet thick, apparently flowed into depressions so that they are locally several times their normal thickness. On these northward-flowing tributaries, upstream from the fault trace, huge more or less rounded masses and lumps of massive sandstone are embedded in contorted shale, which itself contains stringers and drawn-out lumps of sandy layers.

Eastward this fault apparently passes through the highest exposed beds in the next tributary and dies out somewhere in the vicinity of the Greenwood-Hornell quadrangle boundary. Westward it apparently crosses Purdy Creek, as shown on plate 2. This fault as exposed on one of the Purdy Creek tributaries is a steep reverse fault, but the displacement of the fault is indeterminate. However, according to C. E. Fralich, ${ }^{21}$ seismograph records taken about half a mile south of the Greenwood-Hornell quadrangle boundary and 43/4 miles east of the west line show conclusively a displacement of 189 feet on the Tully limestone, down on the south.

Along the Purdy Creek Valley is another similar steep reverse fault which is exposed in a few of its tributaries and at one place on the main creek. The disturbed zone along this fault is not so wide as those along the faults just described, nor are the beds so intensely deformed. Consequently the relations between the beds on the two sides of the fault trace can be better discerned, particularly in a small steep gulch that enters Purdy Creek from the west at a point 1.3 miles south of the Greenwood-Hornell quadrangle boundary. (See fig. 2.)

Key beds that were mapped on both sides of this fault show that it extends northeastward down Purdy Creek Valley for several miles to a point where it dies out into a steep flexure. According to the interpretation given here it displaces the surface rocks between 25 and 50 feet, but it probably increases in throw considerably in depth.

Southwestward this fault curves so as to be exposed in Purdy Creek about 1.8 miles south of the Greenwood-Hornell quadrangle boundary line. At this place the relatively narrow zone of contorted shale along the fault plane is well exposed. The more or less rounded masses of muddy sandstone embedded in this shale are a characteristic feature of these fault zones. (See pl. $4, B$.)

Along Fall Creek, which lies about midway between Purdy Creek and Slate Creek, exposures are rare, but the beds exposed dip at diverse angles, ranging from $4^{\circ}$ to $44^{\circ}$, and some of the beds show

21 Personal communication, August 1936. 
that they were deformed while still plastic. These exposures suggest that a fault similar to those just described runs along the valley of Fall Creek. But if there is a fault here it clearly dies out eastward before it reaches the valley of Bennett Creek, as the DunkirkGowanda contact is unbroken along the west side of the Bennett Creek Valley.

N. $35^{\circ} \mathrm{W}$.

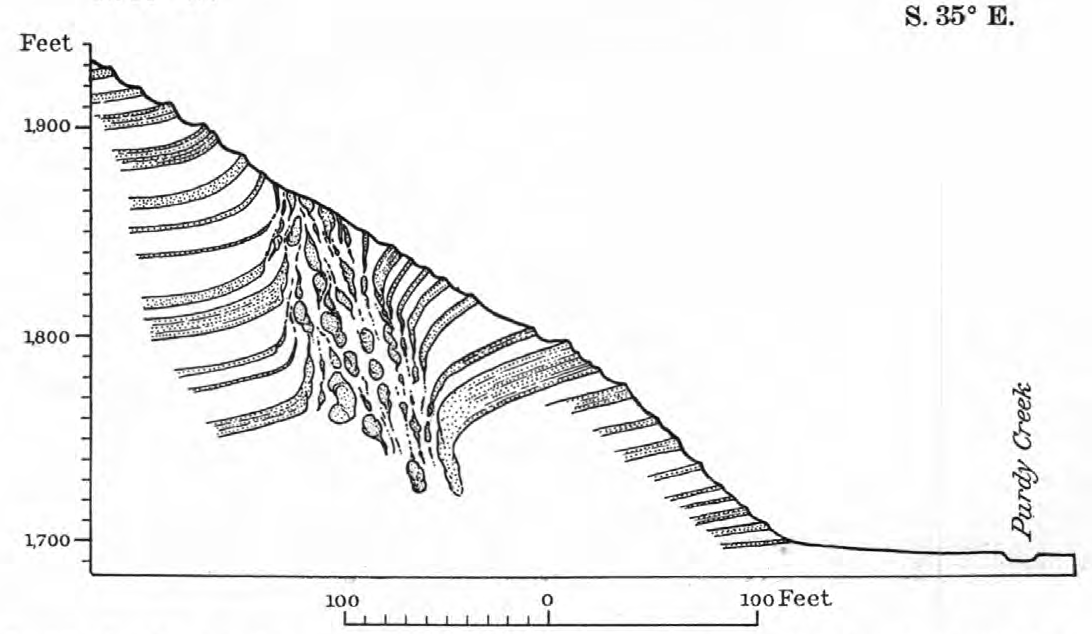

FIgURE 2.- Structure section across the reverse fault that trends northeastward along the valley of Purdy Creek, based on observations made on Purdy Creek and a small tributary gulch 1.3 miles south of the Greenwood-Hornell quadrangle boundary. The zone in which the beds were either highly contorted or the bedding obliterated when they were wet and plastic is unusually narrow in this particular gulch.

INTERPRETATION OF THE DEFORMED ZONES ALONG THE NORTHEASTWARD-TRENDING FAULTS IN THE GREENWOOD AND HORNELL QUADRANGLES

The deformed zones along the northeastward-trending faults in the Greenwood and Hornell quadrangles are restricted to a stratigraphic zone a few hundred feet thick in the lower part of the Gowanda shale and overlying beds. Many of the features of these beds indicate plainly that they were deformed while still wet and plastic. The authors conclude, therefore, that the faults which these deformed zones accompany were active during that part of Upper Devonian time when these beds had just been deposited and were then only shallowly buried on the sea floor. According to this interpretation, these beds were folded and broke and flowed because the sea floor was warped and tilted near these active faults. The beis near the bottom of these deformed zones failed generally as plagtic masses under the confining pressure of the overlying mud and sea water. This sort of plastic yielding is illustrated by the thinning out of sand layers into long stringers, by the sharp bends and swell- 
ings in the sand layers, and by the intricately contorted bedding in the nearly massive shale without the development of cleavage. (See fig. 1.) It is further illustrated by the surfaces of rounded masses of muddy sands one that are embedded in highly contorted shale and look as if the sand mass had been kneaded or swaged under the moderate confining pressure of the mud. Flow lines with many minute transverse compression ridges on these swaged surfaces of muddy sandstone show that they were molded by differential movement between themselves and their enclosing medium while both were soft and plastic. Even parts of sandstone beds that were little deformed have smoothly rounded corners, indicating that the sand was too wet to maintain its rigidity in the engulfing mud.

Sandstone beds higher in this stratigraphic zone that were either close to the sea floor (or perhaps formed the sea floor) behaved like quicksand and flowed without restraint into hollows and formed intimate mixtures with the wet mud. Thus in places all the original bedded structure of that part of the deposit was destroyed.

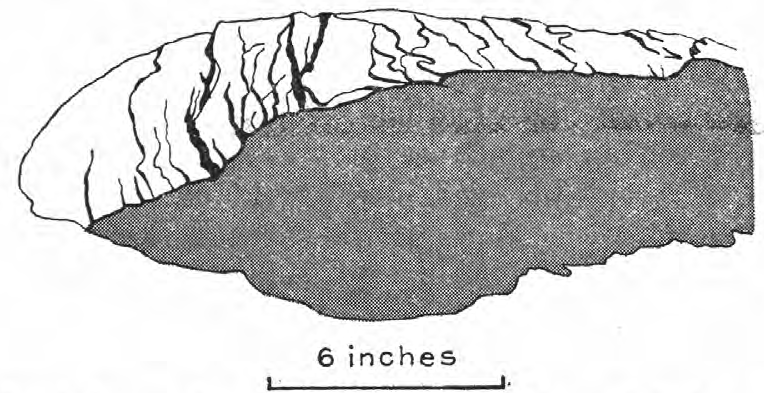

Figure 3.-Microfaults on the upper surface of a sandstone bed that was bent while still uncemented. The under surface of this bed, which was overlain and underlain by wet mud, yielded by folding. The shaded surface of the specimen is normal to the bedding of the deposit. Drawn from a photograph.

The numerous microfaults found on the crests of sharp bends in many of the sandstone beds, however, appear to be particularly significant, because they seem to give a clue to the rate at which the beds in this zone were deformed. In figure 3 is shown a portion of a sandstone bed from the deformed zone on Slate Creek. This bed was bent so that its upper convex surface is broken by a series of small step faults and its under surface is crumpled but not faulted. The fact that there is no trace of these microfaults below the surface and that the under surface was deformed by flowage indicates that the bed was entirely uncemented, so that the grains rolled past one another without leaving within the bed any record of their movement. The conditions were exactly right for this uncemented layer of cleanly sortad, moderately fine-grained sand to fail by fracture 
on its upper surface and by flowage under compressive stress on its under surface.

Perhaps the most reasonable explanation for this failure of uncemented sand by fracture is to be found in the changing relations between the pore spaces of the sand and the water available to fill those pores during deformation. It seems virtually certain that just before deformation the sand grains in this bed were closely packedthat is, so arranged that the pore space was at or near the minimum. This follows from the generalization that close packing of clean, well-sorted sand grains is the stable arrangement and therefore is the arrangement they would assume after deposition on the sea floor and after being shuffled about progressively less as they were buried and compacted beneath a moderate overburden of mud and sea water. Reynolds ${ }^{22}$ many years ago showed that when sand grains are packed in closest arrangement any deformation of the mass of sand throws the grains farther apart and so increases the pore space. If plenty of water is available to keep the increasing pore space full the mass of sand becomes quicksand. Lacking adequate water to fill the pores of the increased bulk of sand the grains are held firmly together, and, as Mead ${ }^{23}$ showed, the mass when strained fails by fracture rather than by plastic deformation.

Had there been an abundance of water available from adjacent beds this sand layer embedded in the wet mud would have become quicksand and failed by flowage everywhere. Evidently there was enough water in the lower part of the bed, or enough was supplied to it during deformation, so that when compressed it failed plastically, and the form of the folded lower surface was preserved by the confining matrix of mud below. But apparently the upper part of the bed failed by a series of fractures, because it contained insufficient water to fill the increasing pores as it was deformed. This seems to indicate that the sand layer was deformed rapidly, for it is highly probable that the overlying mud contained an abundance of water which was available to fill the increasing pores in the sand but that it could not be supplied rapidly enough through the difficultly permeable, fine-grained mud. In other words, had these beds been deformed very slowly, the overlying wet mud, even though somewhat compacted and therefore relatively impermeable, could in all probability have supplied enough water for the sand layer to have become quicksand and failed by flowage.

Granted the conclusion that this bed was deformed rapidly (or perhaps, more properly, suddenly), then, it follows that all these de-

${ }^{22}$ Reynolds, Osborne, On an inversion of ideas as to the structure of the universe, pp. 26-37, Cambridge, 1903.

${ }^{23}$ Mead, W. J., The geologic rôle of dilatancy : Jour. Geology, vol, 33, pp. 687-692, 1925. 
formed beds were deformed rapidly, for similar microfaults are abundant in the sand beds throughout the area just described. Indeed, the whole assemblage of features indicates that these wide, complexly deformed zones adjacent to the northeastward-trending faults resulted from sudden tilting of the sea floor as the fault blocks moved past one another-in short, effects accompanying severe earthquake shocks. The changes in level of some of the key beds in these Upper Devonian sediments are comparable in form and magnitude to many of the changes in the sea floor in the Bay of Sagami in the Tokyo earthquake ${ }^{24}$ of 1923 . The contorted beds, then, are interpreted as large masses of unconsolidated sediment that slid (and flowed) on the steepening slopes of the sea floor while the faults were active, whereas the more diversely jumbled beds and the once fluid mixtures of sand, mud, and coquina found generally on the downthrown sides of these faults are interpreted as probably debris from the newly formed submarine fault scarps.

\section{SIGNIFICANCE OF THE CONTEIMPORANEOUS DEFORIMATION AND DEPOSITION}

Whatever the origin of the features just described, they have a real significance for geologists who attempt to determine the structure of the gas-producing Oriskany sandstone from the attitude of the surface beds in areas to the west and south from the northwestern part of the Greenwood quadrangle. The beds that were laid down over these disturbed zones were not involved in the deformation, most of the faults do not cut them, and many of the sharper flexures and folds in the rocks below the Gowanda are not evident in the beds several hundred feet stratigraphically higher than the deformed zones. Accordingly, broad, gentle folds in these higher beds may conceal at considerable depth below them several narrow folds separated by abrupt flexures or faults.

Some of these features are illustrated by the structure in the southern part of the Greenwood quadrangle. The long, narrow anticline in the extreme southwest corner, about $4 \frac{1}{2}$ miles southeast of Whitesville, is probably cut on its north flank by a long subsurface fault that enters the southwest corner of the quadrangle and extends for perhaps 6 or 8 miles approximately N. $20^{\circ} \mathrm{W}$. This inferred fault may also have caused the northward dip of the beds along the south side of the closed syncline a few miles northeast of the narrow anticline. About 4 miles southwest of the village of Greenwood there is somewhat more convincing evidence of a sub-

\footnotetext{
24 Yamasaki, N., Physiographical studies of the great earthquake of the Kwanto
} district, 1923: Tokyo Imp. Univ., Faculty Sci., Jour., sec. 2, vol. 2, pt. 2, pp. 99-100, 1926. 
surface fault, for there, at least locally, the rocks exposed at the surface dip $6^{\circ}-8^{\circ} \mathrm{S}$., which is unusual for that locality.

In that part of New York State south and west from the intensely disturbed area in the northwestern part of the Greenwood quadrangle the discordance between structure in the rocks exposed at the surface and those at the depth of the Oriskany is due to a combination of two factors-the upward dying out of subsurface faults in the thick shale formations above the Oriskany and the unconformity at the Gowanda horizon, above which the earlier faults and folds do not extend.

\section{CONVERGENCE BETWEEN THE ORISKANY AND SURFACE ROCKS}

All the formations above the Onondaga limestone become progressively more sandy and thicker southeastward across the area. As a result the interval between the rocks exposed at the surface and the gas-producing Oriskany sandstone decreases northwestward; or, stated in a different way, there is a northwestward convergence. The amount of this convergence between the Oriskany and the Rhinestreet in the northeastern part of the area and between the Oriskany and the Dunkirk base in the southwestern part of the area is shown in figure 4. Subsurface faults that change the normal stratigraphic interval, uncertainties in the well records, and errors in the altitudes of the key beds exposed at the surface all contribute to the irregularities of the intervals as shown in this figure. The rate of thickening is probably more nearly uniform than is shown in figure 4.

From the data available (see tables 1-4, pp. 60-65), the average northwestward convergence between the top of the Oriskany and the base of the Rhinestreet is the same as that between the top of the Oriskany and the base of the Dunkirk-approximately 34 feet to the mile. In several smaller areas, where wells are more closely spaced, the convergence is locally less than 34 feet to the mile and at other places as much as 42 feet to the mile for both the Rhinestreet-Oriskany and Dunkirk-Oriskany intervals. This variability is apparently due to local variations in thickness of the Onondaga. The similarity in rate of convergence between the Oriskany and the two contoured horizons is perhaps in part only apparent, owing to the small number of wells that start in the Dunkirk and reach the Oriskany. But, on the other hand, the similarity in rate is probably in large part real, because, as might be expected, the greatest rate of thickening in these formations coincides with the site of most rapid change from shale to sandstone, and it happens that, in that part of the area contoured on the Rhinestreet, the formations below the Rhinestreet-notably the Cashaqua and Standish-are 
rapidly changing southeastward to sandstone and therefore thickening, whereas farther west, in that part of the area contoured on the Dunkirk base, the formations below the Dunkirk are not changing so rapidly to sandstone, and consequently it requires a thicker series of formations to give an equivalent rate of thickening.

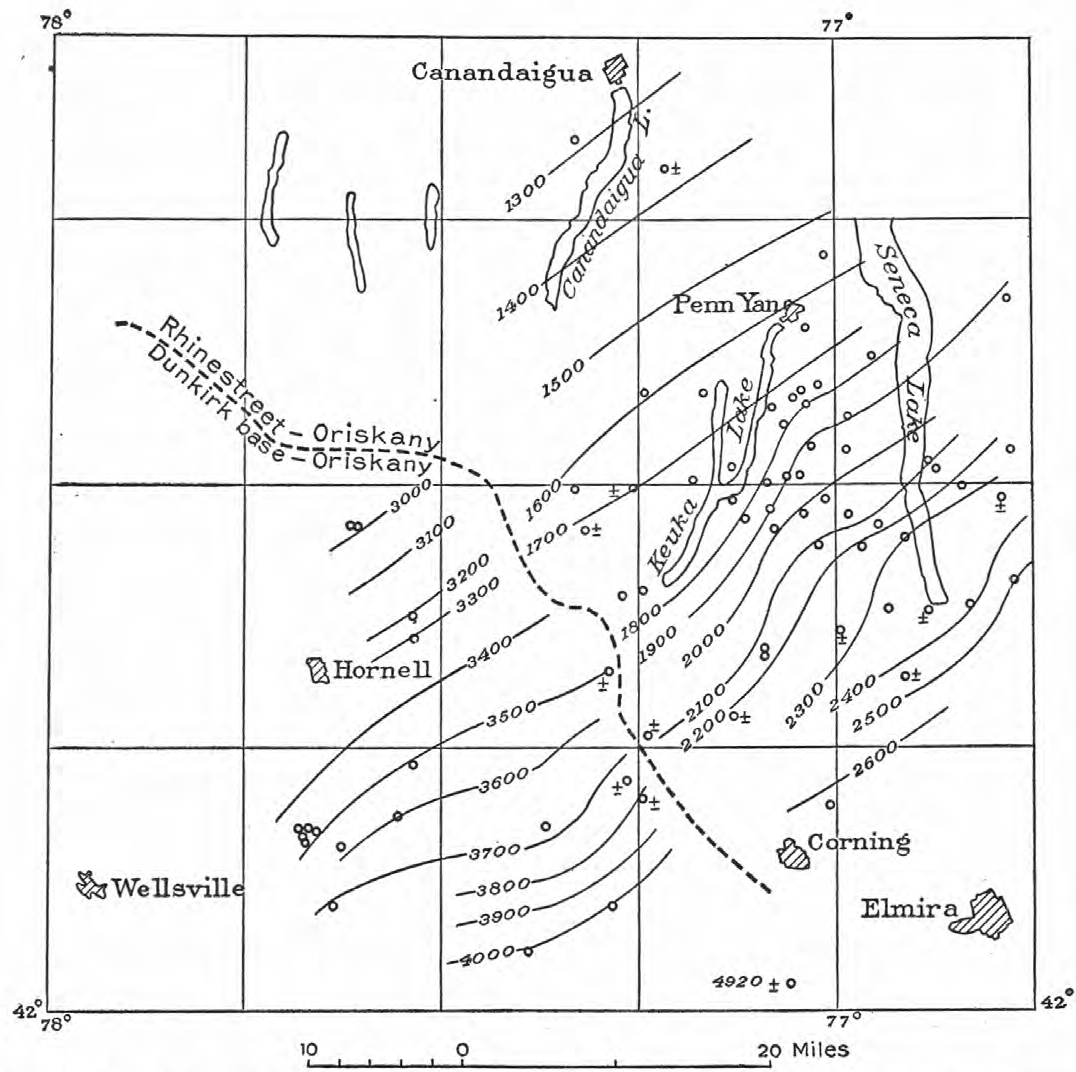

Figure 4.-Map showing the southeastward thickening of the stratigraphic interval between the Oriskany sandstone and the base of the Rhinestreet shale in the northeastern part of the area, and between the Oriskany and the base of the Dunkirk sandstone in the southwestern part of the area. The small circles represent the wells whose records were used to obtain the stratigraphic intervals. The symbol \pm indicates that the interval is known only approximately.

Because of the northwestward convergence between the rocks exposed at the surface and the Oriskany the structure on the Oriskany will differ from that shown on plate 2 , and the departures will be greater where the rocks at the surface are least inclined. In general, the crests of anticlines and domes on the Oriskany whose axes trend northeastward will be offset northwestward, the south flanks steepened and the north flanks flattened, and the amount of closure at the eastern end increased a little. 
In addition to the normal southeastward thickening of the formations two similar factors enter to make the subsurface structure different from that indicated by the attitude of the rocks exposed at the surface. These are local variations in the thickness of the Onondaga and thinning of the shale formations by stretching on relatively steep ends or flanks of domes. The significance of these two factors in the Wayne-Dundee gas field is discussed more fully on pages $54-56$.

Either or both these local factors may also apply to other domes and anticlines in the area and should be kept in mind when trying to determine subsurface structure from the structure of the exposed rocks. The convergence and thinning of the section over relatively steep subsurface slopes can be predicted, at least approximately, but the variations in thickness of the Onondaga are, so far as known, entirely unsystematic.

\section{RELATION OF DRAINAGE TO STRUCTURE}

The courses of the four rivers in the area are evidently related to the structure. The most notable of these is the Canisteo River, which flows southeastward across the Hornell and Woodhull quadrangles into the Corning quadrangle, where it meets the Tioga River. In this course it follows the regional strike of the rocks, so that it is most favorably situated to be influenced by variations in the strike produced by the series of southwestward-plunging folds that it crosses. These variations in strike the river follows in a general way, swinging northeastward into the synclines and southwestward around the anticlinal noses. This relation is particularly striking in the Woodhull quadrangle. (See pl. 2.) The course of the Cohocton River southeastward across the Bath and Corning quadrangles and the course of the Chemung River from Corning to Elmira are both closely similar to that of the Canisteo and, like the Canisteo, probably reflect the positions of the folds quite as faithfully. Unfortunately, however, the structure along the Cohocton and the Chemung is too little known, owing to the lack of suitable key beds, to test the relations adequately. The Tioga, which flows northward: from PennsyIvania into the Corning quadrangle, also swings in part of its course to follow the changing strike of the rocks as it crosses the successive folds but at other places cuts across the folds. Apparently Canaseraga Creek likewise follows the strike of the rocks in the vicinity of Canaseraga and also where it crosses a small fold a few miles northwest of Dansville.

Most of the smaller streams of the area follow courses that are quite independent of the structure. Noteworthy exceptions are the courses of two streams of moderate size-one in the Woodhull quad- 
rangle and the other in the Penn Yan and Ovid quadrangles. Goodhue Creek, the stream in the Woodhull quadrangle, follows the strike around the steeply plunging nose of a rather narrow anticline about 5 miles northwest of the town of Addison. The other stream is Big Stream, which follows the strike of the rocks in a long semicircular course around the north side of the dome on which is located the Wayne-Dundee gas field. Both these streams are incised in bedrock. In the southern part of the Woodhull quadrangle the drainage divide coincides roughly with the structural axis of a large dome so that in an imperfect way the small streams flow out radially from the structural high point. But because nearly the same stream pattern is repeated in other parts of the area where it has no relation to structure this stream pattern is of little exploratory value.

All the rivers that are adjusted to the structure are south of the southern margin of the latest ice sheet of the Wisconsin stage and, having incised their courses deeply into the bedrock, have thereby become adjusted to the structure. Most of this adjustment, however, must have been made during or before the latest glacial stage, because these rivers are now flowing in valleys partly filled with alluvium, which was presumably deposited there during the retreat of the last ice sheet.

In contrast to the rivers, many of the intermediate-sized streams of the area have not yet cut deeply enough into the bedrock to become adjusted to its structure. The greater parts of their courses are still in glacial drift of the last or older glacial stages. But, on the other hand, a large number of the small streams have cut deeply into bedrock through a considerable portion of their length. That these streams are not adjusted to the structure seems to be due largely to the fact that they are tributaries to the master streams or rivers that occupy strike valleys, and therefore their relatively short, steep courses are nearly transverse to the strike of the beds and so are little affected by slight variations in the strike. Where these short streams happen to run along the strike, however, they follow its changes rather closely, as is illustrated by one or two branches of Meades Creek and Mud Creek in the southern part of the Hammondsport quadrangle, near the southwest corner of Schuyler County.

\section{GAS POSSIBILITIES}

In this area accumulations of natural gas in commercial quantities are likely to be found in domes at the Oriskany horizon formed either by the local northeastward plunge of an anticlinal axis or by faults that cut across the axis. But the accumulation of a large volume of gas is dependent not only upon a suitable structural trap but also upon the presence of several feet of sufficiently permeable 
Oriskany sandstone that contains an abundance of salt water on the flanks of the dome. Unfortunately the Oriskany sandstone, though extensive, is not a continuous bed. It thickens and thins and locally is absent. Moreover, these variations are apparently unsystematic, so that it is not possible to predict either the presence or thickness of the reservoir sand. The Oriskany in this area, with a few conspicuous exceptions, as in the vicinity of Elmira, is generally permeable, but it does not everywhere contain salt water. The reason for this is no more evident than the discontinuity of the sand itself. However, the sand usually thins out rather gradually, so that a general idea of the distribution of both the Oriskany sandstone and its saltwater content can be obtained from the well symbols and the accompanying data on plate 2. In a broad way the Oriskany tends to thicken and be more nearly continuous southwestward. In the northeastern part of the area it is thin and discontinuous, and in the extreme northwestern part of the area it is not reported at all or only as mere traces of sand.

The significant features and gas possibilities of individual domes and anticlines are discussed below by quadrangles, beginning with the Wellsville quadrangle, in the southwestern part of the area.

Wellsville quadrangle.-In the extreme southwest corner of the Wellsville quadrangle is the State Line gas field, which late in 1936 had 20 producing gas wells in the New York portion. In addition to these producing wells there were 3 being drilled and 5 containing salt water. On the basis of the records of these wells, which are shown in table 2 (pp. 62-63), the structure on top of the Oriskany sandstone was contoured. (See fig. 5.) Three of the salt-water wells, Nos. 9, 24, and 28 of figure 5, are located on a fault that divides the field into two narrow domes. All three of these wells have abnormally large Tully-Oriskany intervals-No. 9, 776 feet; No. 24, 800 feet; and No. 28, 655 feet. The normal Tully-Oriskany interval, as shown by the records of the other wells, is only a little more than 600 feet. The other two salt-water wells, Nos. 21 and 26, have TullyOriskany intervals of 610 and 605 feet respectively and evidently indicate simple edge-water conditions. It is further worthy of note that most of the displacement along the fault is below the Tully limestone, as the Tully is offset only a few feet or perhaps not at all. At the surface no key horizons were mapped, but by analogy with other folds the structure might be revealed as that of a single elliptical dome, with no suggestion of the faulted furrow that has been demonstrated by drilling. Adequate geophysical prospecting of such simple low domes in the surface rocks should show a small fault or at least a shallow syncline in the Tully, to serve as a warning of a probable fault below. 
Key horizons were mapped and structure contours are shown in only the southeastern part of the Wellsville quadrangle. (See pl. 2.) According to these contours there are two more elongate domes on the northeastward extension of the general anticlinal axis of the State Line gas field. The larger of these domes coincides very nearly with the topographic high area known as Beech Hill. It has a closure of at least 50 feet in the exposed rocks and probably considerably more at the depth of the Oriskany, because, as pointed out on pages $38-42$, the exposed rocks rest with some angular discordance on the

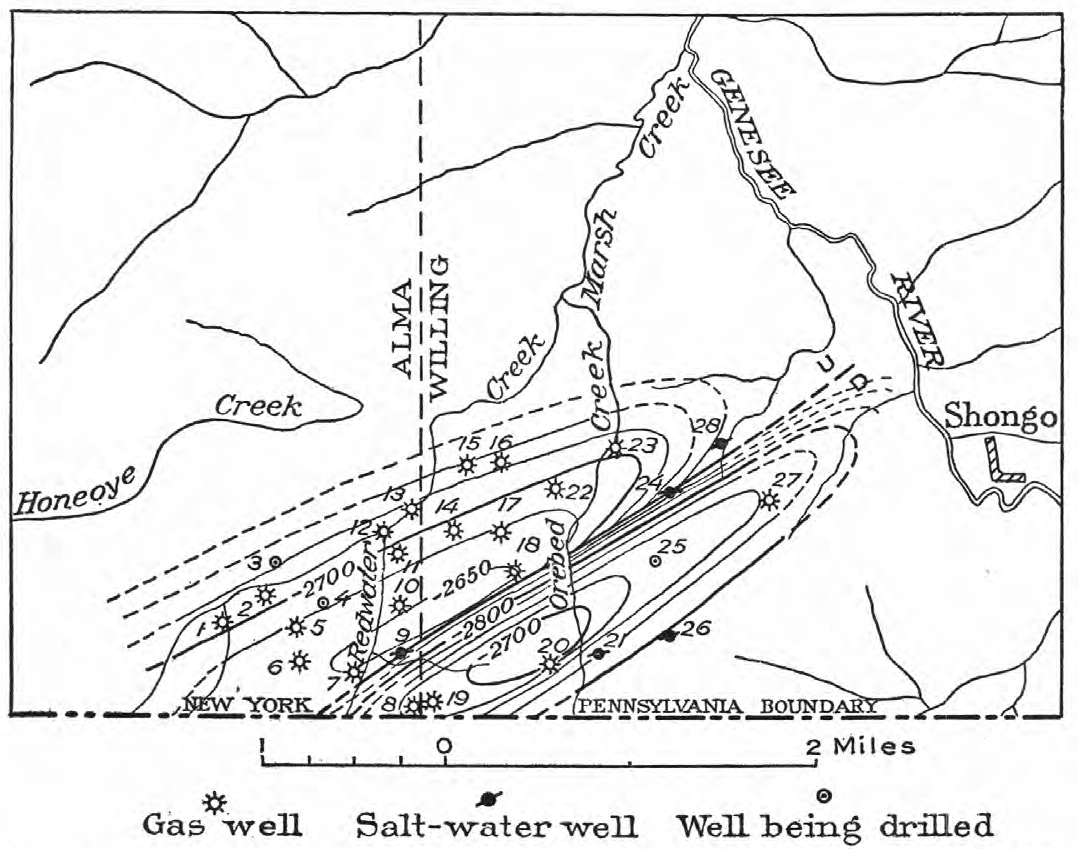

Figure 5.-Map showing the structure of the Oriskany sandstone in the New York portion of the State Line gas field, Allegany County, N. Y. The contours are drawn on the top of the Oriskany sandstone, the contour interval is 25 feet, and the datum is mean sea level. The well numbers refer to well records in table 2 (pp. 62-63).

rocks below the lower part of the series of rocks here designated the Gowanda shale and overlying beds undifferentiated. Below this angular discordance the beds are displaced more by faults and the folds are somewhat steeper.

A sharp reentrant in the contours on the southwest flank suggests that a subsurface fault may cut the south flank of the dome. If this dome is underlain by an adequate thickness of the Oriskany sandstone it should prove to be a productive gas field.

The smaller of these two domes is about 5 miles farther northeast and about 1 mile southeast of the town of Independence. This dome 
has a closure in the exposed rocks of at least 50 feet but, like the larger dome just described, probably has more closure in depth. Also like the other dome, if the Oriskany is present and thick enough, it should be a productive field.

In the southeast corner of the quadrangle, close to the Pennsylvania line and approximately 3 miles southwest of Whitesville, are two domes separated by a narrow syncline similar to the two domes of the State Line field, except that the southern dome is in Pennsylvania. If the narrow syncline represents a fault at the Oriskany horizon, then the northern dome has a closure of more than 75 feet in the exposed rocks and perhaps considerably more at the Oriskany horizon, depending upon the depth of the syncline along its south flank, or upon the displacement of the beds along that syncline if they are faulted in depth. If underlain by a sufficient thickness of Oriskany sandstone, at least the dome north of the Pennsylvania line should be productive.

The dip symbols and fold axes in the rest of the Wellsville quadrangle give a qualitative idea of the structure, but probably too simple an idea, to judge from the contoured area in the southeastern part of the quadrangle and the adjacent part of the Greenwood quadrangle. At only one place, 2 miles west of Andover, are there east and northeast dips that apparently indicate the northeast flank of a dome.

Greenwood quadrangle.- Just north of the Pennsylvania-New York boundary line and nearly in the southwest corner of the Greenwood quadrangle is a long, narrow dome that has a closure on the exposed rocks of a little more than 25 feet. Probably this closure is somewhat greater at the depth of the Oriskany, because, as pointed out on pages 38-42, the exposed rocks rest with some angular discordance on the rocks below the lower part of the series of rocks here designated the Gowanda shale and overlying beds undifferentiated. Below this angular discordance the beds are displaced more by faults and the folds are somewhat steeper. The general aspect of the contours suggests the possibility that the north flank of this small dome is faulted in depth, but only drilling or information obtained from seismograph surveys will adequately reveal the subsurface structure. If there is adequate collecting ground down the dip to the west, it is possible that wells properly located on this long, narrow fold will discover commercial quantities of gas. The possibility of drilling into a fault on this type of dome, however, is large.

About 11/4 miles north of this dome is a similar dome which, however, has more than 75 feet of closure on the exposed rocks. The relatively narrow synclines on each side suggest that both north and south flanks are considerably steeper in depth and may indeed be 
faulted. Like the dome in the south half of the State Line field, it may prove to be productive, particularly if its flanks are bounded by subsurface faults.

About $1 \frac{1}{2}$ miles farther north, 6 miles S. $20^{\circ}$ W. from the village of Greenwood, is a larger and much more promising dome, which has a closure on the exposed rocks of at least 100 feet. The flanks of this dome are so steep that the convergence between the exposed rocks and the Oriskany would not offset the axis of the dome in the Oriskany very much from the observed axis. If an adequate thickness of reservoir sand is present this dome should prove to be a productive gas field. Its south flank is so steep that it seems highly probable that in depth the beds are displaced by a fault of considerable magnitude.

North of this high dome and separated from it by a minor syncline is a smaller dome. This has a closure inferred from dips to be about 50 feet on the exposed rocks. If the Oriskany is present beneath it, this smaller dome may also be productive.

In an area of 12 to 15 square miles west and southwest of Greenwood, the key horizons are peculiarly inexpressive and difficult to reconcile with the dips measured on stratigraphically lower rocks that are exposed in the deep stream valleys. This vagueness of the structural pattern suggests that the rocks below, perhaps a few hundred feet above the Dunkirk, are complexly deformed, as they are in the northwestern part of this quadrangle. If this is so, only geophysical surveys are likely to reveal the subsurface structure.

The Greenwood gas field is about $2 \frac{1}{2}$ miles north by west from the village of Greenwood. It is a small field where, until January 1937, only eight wells had been drilled, but two of these are large, and one the Belmont Quadrangle Drilling Co.'s Coston No. 2 well (No. 5, fig. 6), is the largest gas well in New York State, having an initial open flow rated at 50,000,000 cubic feet. Figure 6 shows an interpretation of the structure on the Oriskany sandstone. This is based in part on the position of the Oriskany in the wells but is largely inferred from the attitude of the surface rocks. In this figure the faults that bound the small graben that closes the dome on the east have been projected vertically downward, in the absence of any information on the slope of the fault planes. At the surface well 6, which is within the graben, enters beds stratigraphically equivalent to those entered at the surface by well 5, which is about 2,400 feet west by north, but in depth the stratigraphic intervals in the graben well thicken, so that the Tully is 42 feet lower and the Oriskany 84 feet lower than in well 5 . This suggests that the western fault bounding the graben increases in throw downward, particularly in the soft shale interval between the Oriskany and the Tully. 
Whatever the explanation, this fault and the dip east of it as shown on figure 6 make a closure at the east end of the field of more than 80 feet on the Oriskany. But evidently the gas reservoir is rather small, because well 1, which was originally a gas well, has been invaded by salt water and abandoned. The Oriskany in this abandoned well is only 33 feet lower than the highest reported position of the Oriskany, which is in well 5.

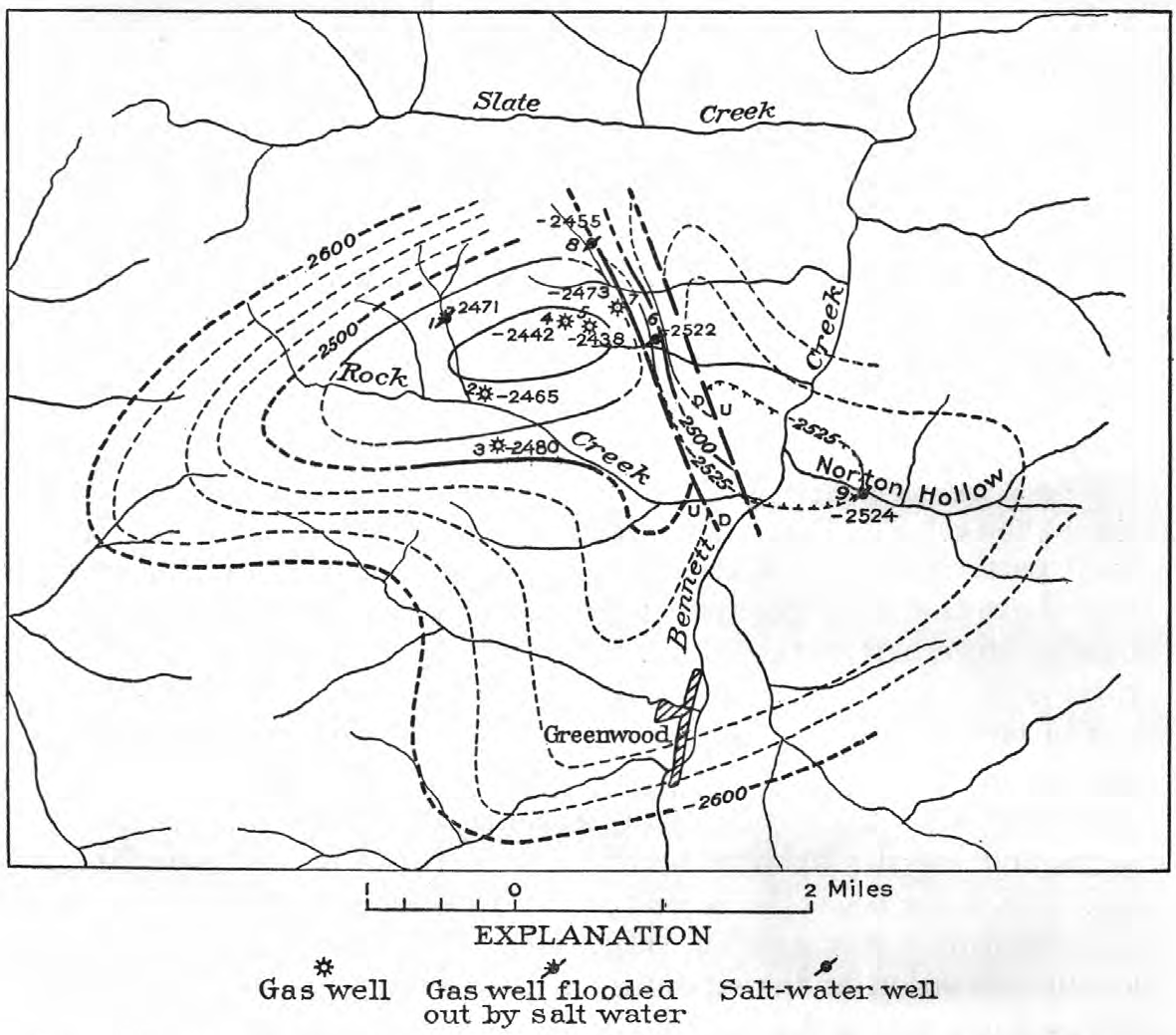

Figure 6.-Map showing the structure of the Oriskany sandstone in the Greenwood gas field as interpreted from drill records and the structure of the exposed rocks. The contours are drawn on the top of the Oriskany sandstone, the contour interval is 25 feet, and the datum is mean sea level. The well numbers refer to well records in table 3 (p. 63).

Well 3 may be close to a subsurface fault, because the record shows that the Oriskany-Tully interval is at least 60 feet less than in the other wells nearby.

Records of the eight wells drilled in the Greenwood gas field and of one well drilled nearby, in Norton Hollow, are given in table 3 , page 63 .

In the northwestern part of the quadrangle the dips and a few altitudes measured on severely deformed key beds in the areas be- 
tween the long faults that trend about N. $70^{\circ}$ E. suggest two elongate subsurface domes, perhaps comparable with the two elongate domes in the State Line field. (See fig. 5.) This inference is worth testing by seismograph surveys.

Woodhull quadrangle.-The Woodhull quadrangle lies adjacent to the Greenwood quadrangle on the east. In its southern part is a large double-topped dome, the Woodhull dome, that has a maximum closure of more than 150 feet on the rocks exposed at the surface. A well drilled by the Lycoming Natural Gas Corporation near the crest of the eastern top of this dome (No. 84, pl. 2), reached the Oriskany horizon at a depth of 4,106 feet but found no reservoir sand-only a mere stringer of coarse sand grains. An abbreviated record of this well is given below, because it shows the relative positions of several of the formation boundaries that are recognizable in well cuttings.

\section{Partial record of Fenner-Taft well, drilled by Lycoming Natural Gas} Corporation in Woodhull Township, Steuben County, N. Y.

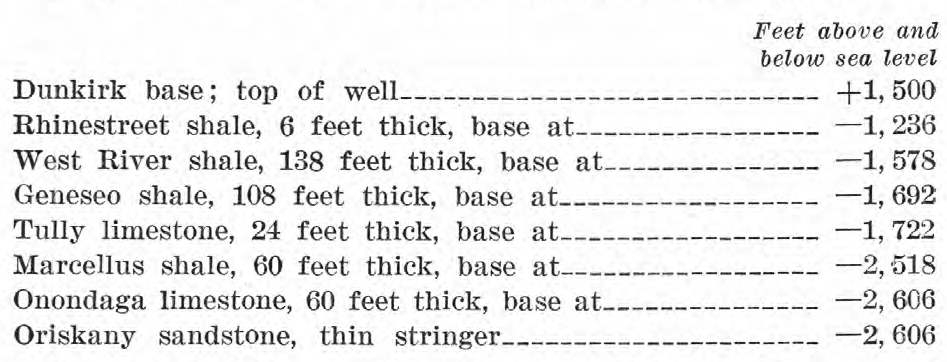

The absence of all but a thin stringer of the Oriskany sandstone in this well makes it doubtful if any Oriskany would be found below the higher top at the west end of the dome only about $3 \frac{1}{2}$ miles from the Fenner-Taft well. But according to Reeves, ${ }^{25}$ the Oriskany underlies one end of the Hebron dome, in Potter County, Pa., and is productive, but it is absent from the other end of the dome. There producing wells are $31 / 2$ miles from dry wells that found no sand. Nevertheless, the Perkins well, drilled by Benedum \& Trees about 6 miles northeast of the Fenner-Taft well, near Addison (No. 83, pl. 2), also found no sand, a fact which suggests that the sand may be absent from a considerable area in that part of the Woodhull quadrangle.

About 8 miles northwest of the large Woodhull dome and $21 / 2$ miles northeast of the village of Jasper is a broad, nearly flattopped dome that makes a sort of structural terrace on a well-defined anticline which extends northeastward from the southern part of

\footnotetext{
${ }^{25}$ Reeves, J. R., Hebron gas field, Potter County, Pa. : Am. Assoc. Petroleum Geologists Bull., vol. 20, pp. 1022-1025, 1936.
} 
the Greenwood quadrangle across the Woodhull quadrangle into the Bath quadrangle. This dome has about 35 feet of closure on the surface rocks and probably a similar or greater closure at the Oriskany horizon. Because of the flatness of this dome it is probable that the axis of the dome on the Oriskany will be found about 0.3 mile northwest of the crest observed in the exposed rocks.

No wells have been drilled very close to this dome, but the Edna McCorkle well (No. 82, pl. 2), drilled by Fields, McCorkle et al. about $51 / 2$ miles northeast on the south flank of the anticline, struck the Oriskany sandstone and a flow of salt water. The McCormick well (No. 79, pl. 2), drilled by the Rex Natural Gas Co. on the anticline nearly 9 miles southwest of the dome in the Greenwood quadrangle, also struck salt water in the Oriskany. If the Oriskany is present under this dome there apparently is enough salt water in the Oriskany on other parts of the anticline to force gas into the closed area, and the dome should be productive.

Corning quadrangle.-The structure of the Corning quadrangle is known adequately only in the southwestern part. Elsewhere key horizons are lacking or unsatisfactory. But in the northeastern part of the quadrangle, on Post Creek, and in the adjacent part of the Elmira quadrangle the dips and a few points on a key bed outline a fairly good-sized dome. The Callahan deep well (No. 87, pl. 1), located high on this dome and drilled by the Corning Glass Co., penetrated 42 feet of the Oriskany. In the top of the sand a little gas was found, and at the bottom a little salt water, but most of the sand, though porous, was dry. This is regarded as a conclusive test of this dome. A shallow well 100 yards or so northwest of the deep well has produced enough gas to supply the Callahan home for many years. The stratigraphic horizon from which this small flow of gas comes is not known.

Elmira quadrangle.-The large dome on which the city of Elmira is located has long been known. A well drilled just east of the city (No. 93, pl. 2), apparently near the axis of the anticline but somewhat east of the highest part of the dome, penetrated 30 feet of the Oriskany sandstone but found it dry and tightly cemented. Moreover, the other 3 wells in this quadrangle (Nos. 90-92, pl. 2), also found the Oriskany dry, so that the gas possibilities of this quadrangle seem small.

Watkins quadrangle.-The gas possibilities of the Watkins quadrangle were discussed in a press memorandum ${ }^{26}$ issued in 1935. Data subsequently obtained have led to some revision of the con-

\footnotetext{
${ }^{26}$ Bradley, W. H., Structure and gas possibilities of the Watkins quadrangle, N. Y. : United States Department of the Interior Press Mem. 101944, 14 pp., June 1935.
} 
tours shown on the preliminary map accompanying that memorandum.

Across the southern part of the quadrangle, about $1 \frac{1}{2}$ miles south of Montour Falls, is a conspicuous anticline having two domes. The western of these domes has a closure on the exposed rocks of a little more than 75 feet and the eastern one a little less than that. The gas possibilities of these domes seem very small, because the Watkins Salt Co.'s well (No. 44, pl. 2), drilled on the axis but almost 3 miles west of the top of the western dome, found that the Oriskany sandstone was absent; the Hines well (No. 46), drilled by Vandergriff on the south flank of the anticline, found only a trace of the Oriskany sandstone; and the Hager well, on the anticlinal axis nearly 5 miles northeast of the Hines well, in the adjacent Ithaca quadrangle, found, no sand. In January 1937 the Washburn well (No. 47) was completed on the eastern dome and found no sand. On the western dome another well (No. 45) was being drilled in February 1937.

The broad dome whose center coincides with the town of Watkins has been demonstrated to be nonproductive by two old wells, the Hill well (No. 41, pl. 2), at the west edge of town, and another (No. 42) on the Fair Grounds, at the south edge of town. The Hill well is, reported to have struck shows of gas before reaching the Oriskany but only salt water in the Oriskany. Still another well on this dome, the Belmont Quadrangle Drilling Co.'s Whalen No. 1 (No. 40, pl. 2), which is about 3 miles west of Watkins, struck salt water in the Oriskany sandstone. A peculiar feature of this dome is the apparent thinning of the Rhinestreet-Oriskany interval on the top of the dome. At the Whalen No. 1 well, 3 miles west of Watkins, this interval is 2,335 feet, but at the Hill well, on the west edge of the town of Watkins, it is only 2,287 feet, whereas the southeastward thickening of the formations would lead one to expect it to be at least 50 feet greater than in the Whalen No. 1 well.

A group of small but long-lived wells in the town of Watkins (not shown on pl. 2) have for many years produced gas from the Marcellus shale, which overlies the Onondaga limestone.

A little additional field work done in June 1936 on the dome east of Watkins shows that it is a rather narrow feature with somewhat more closure than was formerly supposed. Its axis trends only a little east of north, and its south end is cut by a long fault that trends a little west of north. In July 1936 a well (No. 38, pl. 2) drilled near the south end of the dome by J. F. Carpenter struck about 70,000 cubic feet of gas and salt water in the Oriskany. Apparently this well is located down the northwest flank of the dome. Later another well (No. 37) was drilled about on the crest of the dome but found 
no sand. These wells have tested adequately the gas possibilities of the dome.

At the Oriskany horizon the long low dome shown in the northwestern part of the quadrangle is apparently only a long anticlinal nose plunging southeastward from the flank of the Wayne-Dundee gas field. Wells drilled on it found the sand thin and dry, or absent.

In the northeast corner of the quadrangle is the west end of a large dome. One well on the north flank of this anticline, the McNetton well (No. 30, pl. 2), drilled by the Hector-Valois Oil \& Gas Co. nearly on the boundary between the Watkins and Ovid quadrangles, found only 3 feet of Oriskany, and that was dry. Another well, the Houseworth well (No. 31), drilled by J. F. Carpenter on the south flank of the anticline a little more than $2 \frac{1}{2}$ miles southeast of the McNetton well, penetrated 12 feet of Oriskany that was also dry. But the record of the Houseworth well shows an abnormally large TullyOriskany interval. This well may therefore be dry only because the hole passed through or close to a subsurface fault that cuts the south flank of the anticline.

Hammondsport quadrangle.-The Hammondsport quadrangle, which lies west of the Watkins quadrangle, contains but one domethe Wayne-Dundee gas field, which was discovered in 1930. This dome has two crests at the Oriskany horizon, though the key beds exposed at the surface do not even suggest the western top-the Wayne part of the gas field. The marked difference between the structure as drawn on the base of the Rhinestreet and as drawn from abundant well data (see table 4, p. 64) on the Oriskany sandstone is shown in figure 7 . The southeastward divergence between the Rhinestreet and the Oriskany does not account for all the departures between these two structural patterns. Instead, the departures are due largely to two local factors-an unusual eastward thickening of the Onondaga limestone and a thinning of the soft shale formations by squeezing on the relatively steep west end of the dome. In the western, or Wayne, part of the gas field the Onondaga averages about 65 feet in thickness, whereas in the eastern, or Dundee, part it averages about 95 feet. This local variation in thickness of the Onondagai adds about 20 percent to the normal southeastward divergence. But the eastward divergence between the Rhinestreet and the Oriskany' across the Wayne-Dundee gas field is greater than the eastward component of the normal southeastward divergence plus the local eastward thickening of the Onondaga. Because this abnormal divergence takes place eastward, it presumably is not accounted for by: local abnormally rapid thickening of the strata and suggests that the thick, soft shale formations were squeezed and thereby thinned somewhat on the steeper west end of the dome although the dip is only 


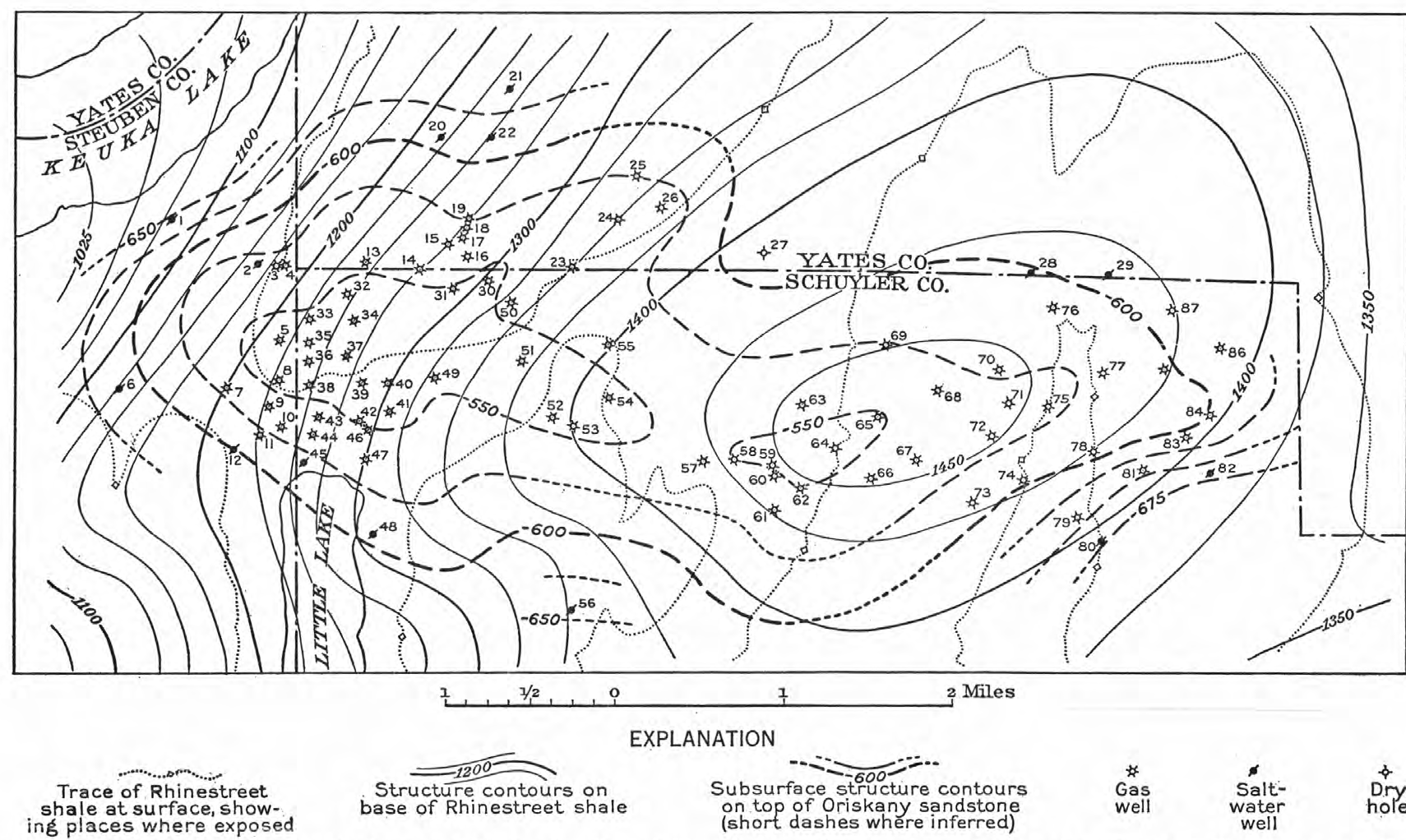

Figure 7.-Map of the Wayne-Dundee gas field showing the relations between the structure of the rocks exposed at the surface and the subsurface structure. The contour interval for both sets of contours is 25 feet, and the datum is mean sea level. Only those wells that were used for control of the subsurface structure are shown. The well numbers refer to the well records in table 4 , pages $64-65$. 
$11 / 2^{\circ}$ to $2^{\circ}$. At any rate, the Rhinestreet-Oriskany interval in the wells at the western edge of the Wayne-Dundee gas field is almost exactly the same as in a well 4 miles farther northwest (No. 20, pl. 2), across Keuka Lake, which indicates that the shale formations do not there show the usual southeastward thickening. Or, stated differently, the shale section in the wells at the west edge of the gas field is apparently thinned by just the amount that the Rhinestreet and Oriskany normally diverge southeastward-that is, about 135 feet, in the 4 miles.

The two parts of the Wayne-Dundee field are evidently separated not only by a low saddle at the Oriskany horizon but also by an area in the saddle where the porosity of the sand is less. The gas from, the eastern, or Dundee, part contains hydrogen sulphide and is called "sour," whereas that produced from the Wayne part does not and is referred to as "sweet." Moreover, on each side of the saddle the wells closest to the zone where the sand is cemented have yielded the smallest flows of gas.

Bath quadrangle.-Unfortunately the structure of the Bath quadrangle, which lies west of the Hammondsport quadrangle, is very imperfectly known, owing to the lack of suitable key beds everywhere but in the southwestern part. Only one small area about $31 / 2$ miles northwest of Avoca shows any closure on the surface rocks, and here the closure is indicated only by one north dip reading and another northeast reading. A few other dip readings nearby suggest that the dome is small. The Charles Matoon well (No. 61, pl. 2), drilled in 1936 on the northwest flank of this dome, found the Oriskany sand dry.

Hornell quadrangle.-The Hornell quadrangle lies immediately north of the Greenwood quadrangle, but its structure is rather simple. One of the faults from the Greenwood quadrangle extends northeastward along Purdy Creek into the Hornell quadrangle. Between this fault and the town of Canisteo is a small dome which has so little closure that it is probably represented at the Oriskany horizon by an anticlinal nose whose rate of southwestward plunge is more gentle beneath the area of closure in the exposed rocks than elsewhere.

About $3 \frac{1}{2}$ miles southwest of Hornell approximate altitudes on several key horizons and the dips indicate a small dome. Additional field work would be necessary to verify the structure indicated. A well (No. 69, pl. 2) drilled in 1936 about three-quarters of a mile southeast of this dome found salt water in the Oriskany sandstone.

About 2 miles east of Hornell is a large, nearly level-topped dome on an anticline that extends from the fork in Keuka Lake, in the southern part of the Penn Yan quadrangle, southwestward across 
the Bath and Hornell quadrangles. This broad dome apparently has only a few feet of closure on the exposed rocks, yet the number of control points is so small there is reasonable room for uncertainty. About 21/2 miles northeast of this dome is the Willis well (No. 66, pl. 2), which struck a small flow of gas in the Oriskany. About $1 \frac{1}{3}$ miles northeast of the dome is the Thomas Moss well (No. 67), which flowed at the rate of 200,000 cubic feet of gas a day after being shot. The Oriskany sandstone there is somewhat shaly, and its permeability is therefore low. A well (No. 68, pl. 2) drilled by the Wittmer Oil \& Gas Co. on the Bennett farm at the east end of this dome struck the Oriskany, which there contained salt water. Another well 1.4 miles north, on the Ford farm (No. 65, pl. 2), drilled by Cunningham, also struck the Oriskany, which there contained not only salt water but about 150,000 cubic feet of an incombustible gas thought to be carbon dioxide.

In the northern part of the Hornell quadrangle is a small structural terrace on the north flank of which three wells have been drilled. One, Jacob Mangin well (No. 63, pl. 2), drilled by the Gas States Corporation and apparently located near the high point on the subsurface structure, found shows of gas in the Marcellus shale and the Onondaga limestone, but the Oriskany had neither gas nor salt water. The Eichorn well (No. 62, pl. 2) drilled by the same company half a mile farther west and little lower on the anticline, found salt water in the Oriskany. A third well (No. 64, pl. 2), drilled on the south flank of the subsurface structure, found no sand. These wells constitute a conclusive test of this small terrace.

Canaseraga quadrangle.-The Canaseraga quadrangle lies north of the Wellsville quadrangle at the west edge of the area mapped on plate 2. Key horizons were mapped only in a small area in the northeast corner of the quadrangle. Elsewhere dip symbols suggest the local attitude of the exposed rocks. Two northeast dips a little west of the center of the quadrangle suggest closure at the northeast end of a dome, but these should serve only as a guide to a locality that may be worth further geologic study or perhaps geophysical prospecting. Near the west line of the quadrangle is a well (No. 72, pl. 2) that is reported to have struck a small flow of gas (see table 1, p. 62), but the horizon from which it came is unknown. The attitude of the rocks near this well is also unknown.

Wayland quadrangle.-The Wayland quadrangle is in the northwestern part of the area, immediately north of the Hornell quadrangle. Near its center, about $11 / 2$ miles southeast of the village of Springwater, is a small structural terrace on a fairly well defined anticline. This structural feature may be a small dome, but the information is not adequate to be sure of the closure. Even if it is 
a dome with considerable closure, its gas possibilities are slight because it is apparently close to the extreme northwest limit of the Oriskany sandstone and also because it is far north of the nearest well that has produced gas from the Oriskany.

Naples quadrangle.-Thick glacial deposits conceal the rocks in much of the southeastern part of the Naples quadrangle, so the structure there is virtually unknown. In other parts of the quadrangle no domes were found.

Penn Yan quadrangle.-The Penn Yan quadrangle lies north of the Hammondsport quadrangle. About midway between the WayneDundee gas field and the town of Penn Yan is a dome comparable in size with the Wayne-Dundee dome. However, it has been conclusively demonstrated by four wells drilled near its top that the area underlain by the dome in the surface rocks is barren of gas.

Ovid quadrangle.-In the Ovid quadrangle, north of the Watkins quadrangle, though faults and relatively steep dips, which commonly accompany domes in this part of the State, are rather numerous, only three domes have been found, and these are too small to serve as traps for natural gas in quantities large enough to be commercially attractive.

The structural feature most likely to trap a small quantity of gas is in the southeastern part of the quadrangle $61 / 2$ miles due east of the village of Dundee. It is closed on the north by a fault that trends northeastward and that drops the beds on the north with respect to those on the south. It is closed on the east and west by comparatively shallow synclines. On the south the contours on the Rhinestreet show this feature as a small anticlinal spur that extends northwestward from a larger dome in the northeast corner of the Watkins quadrangle, but the southeastward thickening of the beds should give this small feature 30 feet or more of closure on the south at the Oriskany horizon. Two wells on the west flank of this structural feature suggest that this small trap may contain gas. One, the C. S. Callum well (No. 27, pl. 2) drilled by E. H. Adams et al., which is nearly 2 miles west by south from the high point on this dome, struck salt water, whereas the other (No. 28), three-quarters of a mile southeast (the E. Adams well, drilled by the Hector-Valois Oil \& Gas Co.), penetrated about 6 feet of the Oriskany sandstone, which yielded a small flow of gas.

On the east shore of Seneca Lake near the mouth of Mill Creek is a small dome whose axis trends northward. Southwestward across the lake is another small dome. Neither of these is large enough to warrant prospecting, and the dome on the west side of the lake is so nearly flat that it would be only a structural terrace sloping gently southeastward at the Oriskany horizon. 
Phelps quadrangle.-The Phelps quadrangle is north of the Penn Yan quadrangle and, like that quadrangle, contains one dome, which drilling has shown to be without gas.

\section{OIL Possibilities}

In the southwestern part of the area shown on plate 2 there are several small oil fields. As in other parts of the Appalachian region the oil has accumulated in synclines in sandstone beds that contain no water. In this area the sandstone beds probably though not certainly belong to the Dunkirk sandstone. The wells in these fields are shallow (800 to 1,300 feet). They have small average yields, ranging from less than 1 to about 2 barrels of oil a day, but they are long-lived, and the oil brings a comparatively high price.

Greenwood quadrangle.-In the Greenwood quadrangle there are two oil fields, both near the west edge of the quadrangle, one about 4 miles west by north from the village of Greenwood and the other about $4 \frac{1}{2}$ miles southwest of Greenwood. By analogy with these two fields it seems reasonable to expect that the broad-bottomed syncline at and near Rexville and the large closed syncline about $31 / 2$ miles southeast of Rexville would be worth prospecting for shallow oil.

Wellsville quadrangle.-At Whitesville, in the southeast corner of the Wellsville quadrangle, is a deep syncline that apparently extends southwestward to the Pennsylvania line, though it may be closed by a low transverse structural ridge connecting the two domes on both sides of the syncline. So far as the authors know, only a few oil wells have been drilled in this syncline, and these are about 2 miles southwest of Whitesville. By analogy with other nearby oil pools, it seems reasonable to expect that oil might be found in this syncline throughout much of its extent in New York State. 
WELL RECORIS

TABLE 1.-Records of wells to the Oriskany in Steuben, Yates, and parts of the adjacent counties, New York, not including those given in tables 2-4

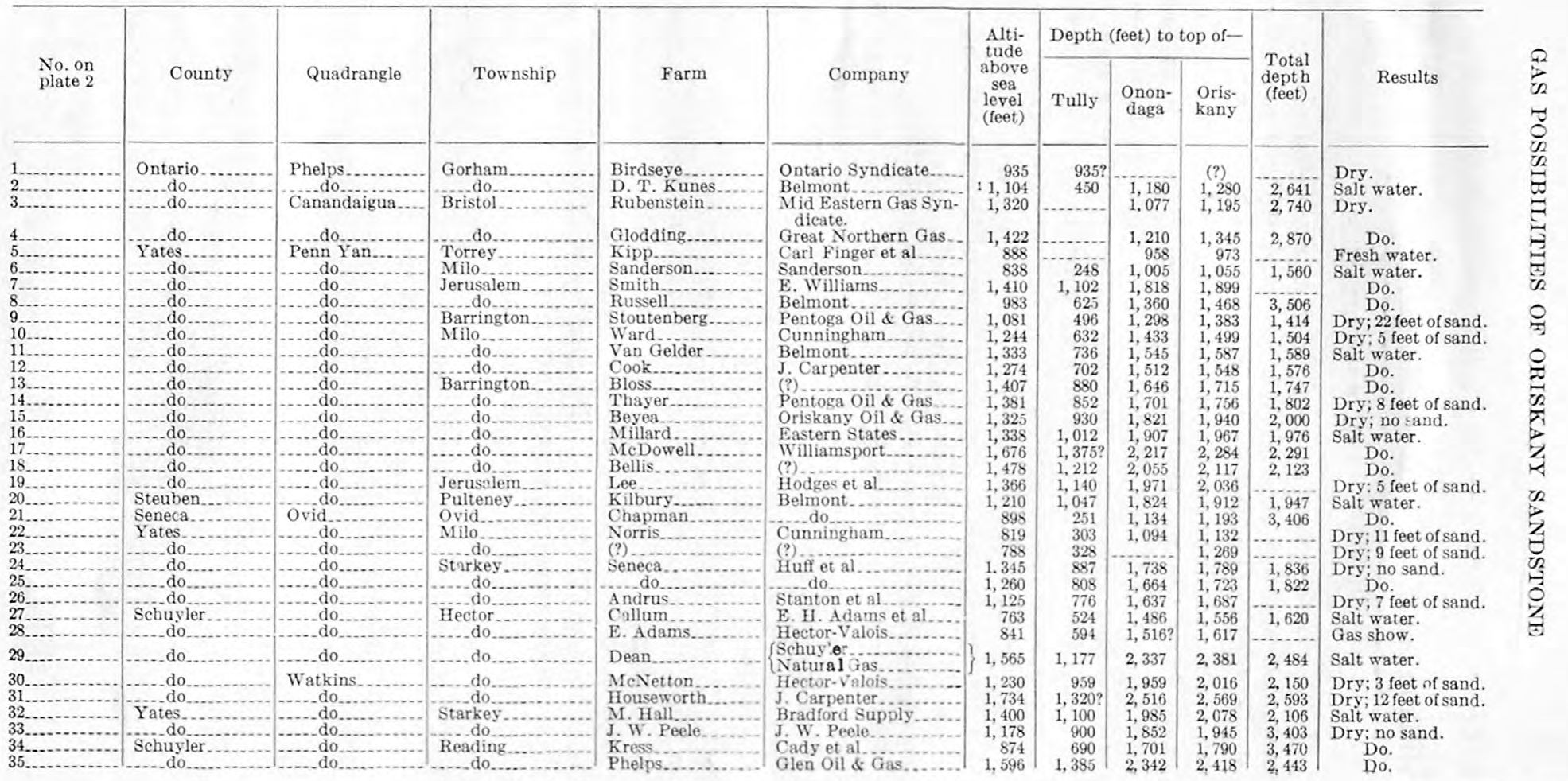

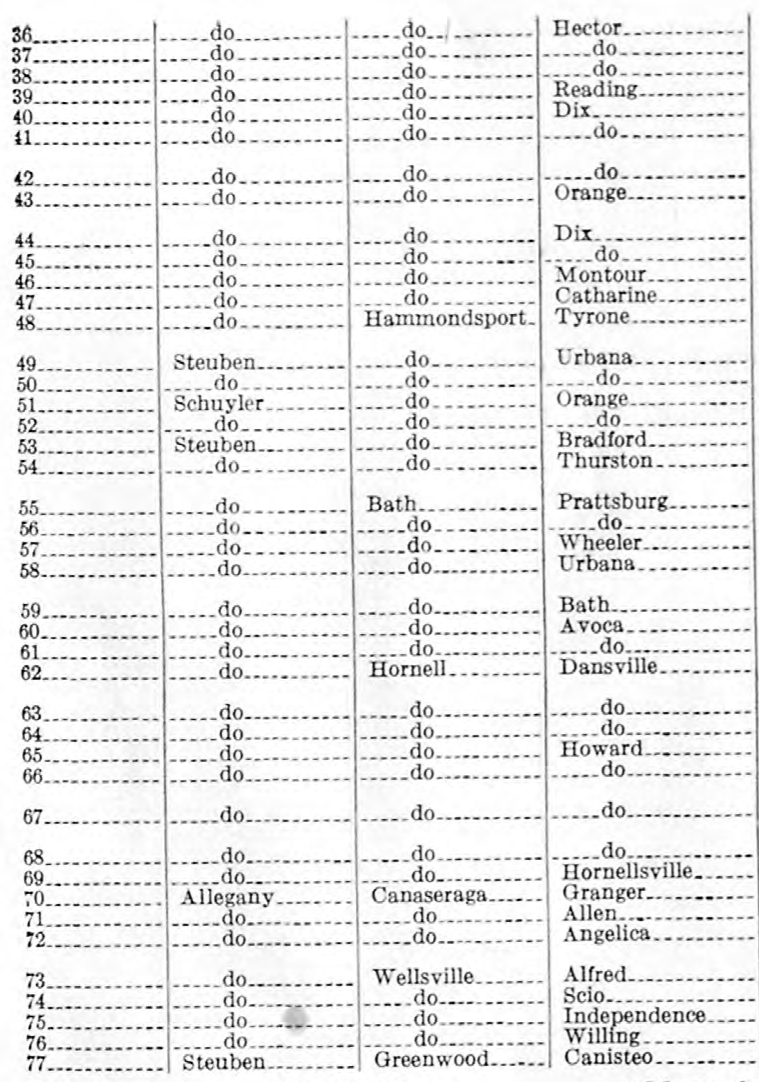

1 Measured with an altimeter.

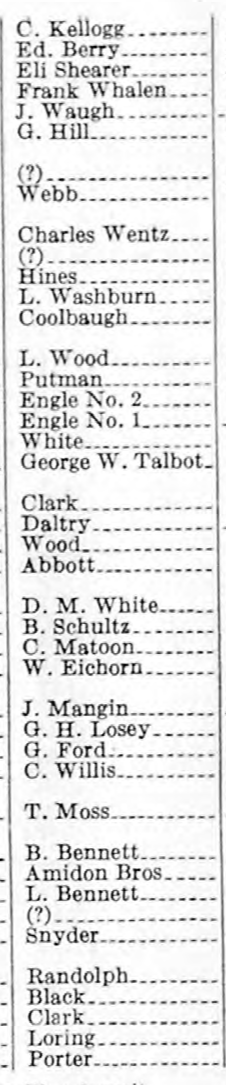

${ }^{2}$ Measured with a transit

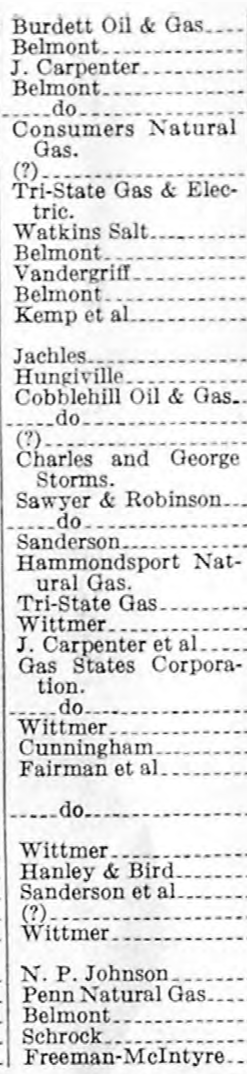

Abandoned in Tully.

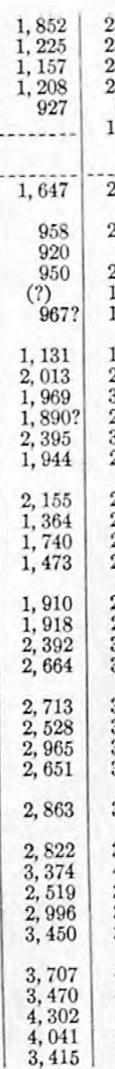

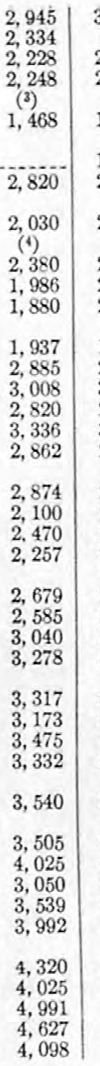

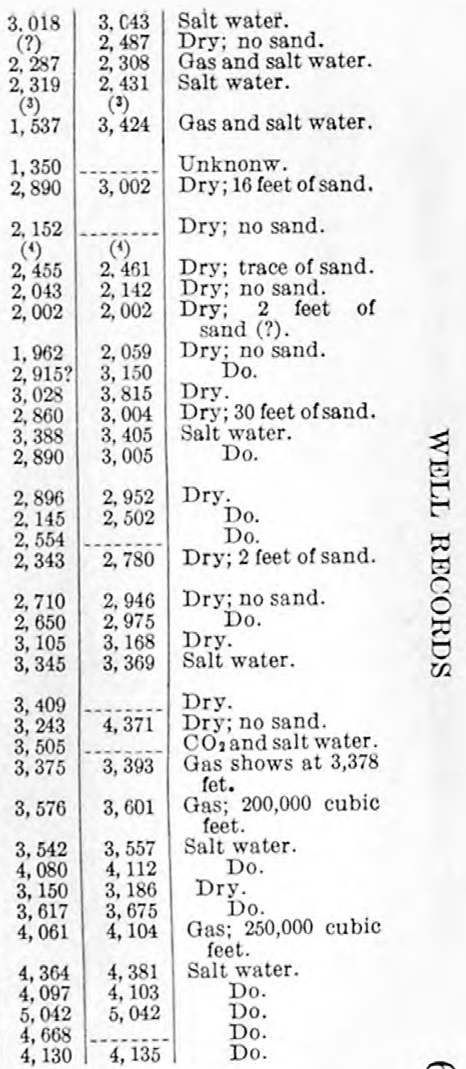

‘ Being drilled Feb. 15, 1937. 
TABLE 4.-Records of wells in the Wayne-Dundee gas field

\begin{tabular}{|c|c|c|c|c|c|c|c|c|c|c|}
\hline \multirow{2}{*}{$\begin{array}{l}\text { No. on } \\
\text { fig. } 7\end{array}$} & \multirow{2}{*}{ County } & \multirow{2}{*}{ Township } & \multirow{2}{*}{ Farm } & \multirow{2}{*}{ Company } & \multirow{2}{*}{$\begin{array}{c}\text { Altitude } \\
\text { above sea } \\
\text { level } \\
\text { (feet) }\end{array}$} & \multicolumn{3}{|c|}{ Depth (feet) to top of- } & \multirow{2}{*}{$\begin{array}{l}\text { Total } \\
\text { depth }\end{array}$} & \multirow{2}{*}{ Results } \\
\hline & & & & & & Tully & $\begin{array}{l}\text { Onon- } \\
\text { daga }\end{array}$ & Oriskany & & \\
\hline & Steuben. & Wayne. & Canfield.. & Jackels. & 895 & 543 & 1,477 & 1,543 & 1,548 & Salt Fwater. \\
\hline & ..... do ... & .....do.. & Schmoker & Belmont. & 1,071 & 754 & $\begin{array}{l}1,476 \\
1,579\end{array}$ & $\begin{array}{l}1,045 \\
1,642\end{array}$ & $\begin{array}{l}1,040 \\
1,649\end{array}$ & $\begin{array}{l}\text { arywater. } \\
\text { Do. }\end{array}$ \\
\hline & ..... do & .......do. & Gleason... & Cunnigham. & 1,143 & 803 & 1,653 & 1,718 & 1,726 & Gas. \\
\hline $4 \ldots$ & .....do do & ...... do & Wixon.... & Finger Lakes.. & 1,169 & 827 & $\begin{array}{l}1,030 \\
1,670\end{array}$ & 1,738 & 1,756 & Do. \\
\hline & ..... do & ....do.. & Bigelow No. 3 & Lamoka........ & 1,178 & 816 & 1,667 & 1,719 & 1,735 & Do. \\
\hline & ..... do. & ..... do. & Earnest No. 2. & Tri-State... & 1,047 & 752 & $\begin{array}{l}1,001 \\
1,592\end{array}$ & $\begin{array}{l}1,19 \\
1,658\end{array}$ & $\begin{array}{l}1,666 \\
1,660\end{array}$ & Salt water. \\
\hline & ........ do & ...... do & Baptist Cemetery. & .... do... & 1,117 & 766 & $\begin{array}{l}1,032 \\
1,616\end{array}$ & $\begin{array}{l}1,000 \\
1,686\end{array}$ & 1,695 & Gas. \\
\hline $8 \ldots$ & ..... do & ....do do & Wyss No. $2 . . . .$. & do........... & 1,190 & 820 & 1,676 & 1,735 & 1,746 & Do. \\
\hline $9 \ldots$ & ..... do do & do... do & Bliss.......... & Reserve Oil & 1,165 & 803 & 1,645 & 1,716 & 1,736 & Do. \\
\hline 10. & ......do. & ...do. & Earnest.. & Finger Lakes. & 1,156 & 803 & $\begin{array}{l}1,040 \\
1,652\end{array}$ & 1,723 & 1,735 & Do. \\
\hline $11 .-$ & do & do & Smith & Crescent Production.... & 1,149 & 797 & 1,650 & 1,723 & 1,744 & Do. \\
\hline $12 .$. & do ......... & ...... do & Mitchell.... & Cunningham............ & 1,169 & 843 & 1,700 & 1,770 & 1,786 & Salt water. \\
\hline 13. & Yates... & Barringtor & Gasper... & Belmont... & 1,309 & 950 & 1,793 & 1,863 & 1,875 & Gas. \\
\hline 14. & ..... do.. & ......do do & Miles.-. & ......do... & 1,442 & 1,068 & 1,925 & 1,997 & 2,010 & Do. \\
\hline $15 \ldots$ & .....do do & .....do do & Hayes No. 1 . & 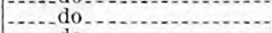 & 1478 & 1,123 & 1,989 & 2,044 & 2,050 & Do. \\
\hline 16. & ..... do & $\ldots$ do & Hayes No. 2 & $\ldots$ do & 1,474 & 1,112 & 1,974 & 2,032 & 2,043 & Do. \\
\hline 17. & do & ..do.. & Reep No. 1 & R. E. Decker & 1,476 & 1,132 & 1,990 & 2,050 & 2,059 & Do. \\
\hline 18. & do & do........ & Reep No. 2. & $\ldots$ do ............... & 1,477 & 1. 135 & $\begin{array}{l}1,950 \\
1,989\end{array}$ & 2,049 & 2,059 & Do. \\
\hline $19 .$. & do...... do & $\ldots . .$. do & Martin & Belmont.... & 1,477 & 1,140 & 1,980 & 2,052 & 2,065 & Do. \\
\hline & .... do & .... do. & Bailey ............ & J. Carpenter- & 1,433 & 1,151 & 1,994 & 2,040 & 2,049 & Salt water. \\
\hline & .... do... & ......do. & Bellis..... & R. E. Decker & 1,478 & 1, 212 & $\begin{array}{l}1,97 t \\
2,055\end{array}$ & 2,117 & 2,123 & Do. \\
\hline $22 \ldots$ & ..... do & .....do & Weldy .......... & Interstate Natural Gas.. & 1,476 & 1,187 & 2,024 & 2,087 & 2,106 & Do. \\
\hline $23 \ldots$ & ..... do & ....do_. & Boorm & Cunningham ................ & 1,286 & 920 & 1,782 & 1,853 & 1,869 & Gas. \\
\hline 24. & .... do . & .... do & Van Gordon. & Belmont........ & 1,434 & 1,076 & 1,920 & 1,999 & 2,010 & Do. \\
\hline $25 \ldots$ & .... do & .....do do & Hammer......... & ....................... & 1,613 & 1,260 & 2,105 & 2,187 & 2,197 & Do. \\
\hline & .....do... & do & Faucett ........... & Oriskany Drilling & 1,380 & 1,020 & 1,885 & 1,951 & 1,958 & Do. \\
\hline 27. & .... do ... & .....do . & Sworts & Williamsport Oil \& Gas. & 1,125 & 771 & 1,676 & 1,740 & 1,785 & Dry; 9 feet of sand. \\
\hline 28. & ..... do.. & ..... do & Bassett No.2. & J. Carpenter............... & 1,437 & 1,074 & & 2,034 & 2,060 & Salt water. \\
\hline 29. & $\ldots$ do $\ldots$ & ..... do . & $\ldots . .$. do $\ldots . . .$. & ..... do & 1,473 & & 1,995 & 2,091 & 2,127 & Do. \\
\hline & Schuyler & Tyrone. & Q. A. Earnest & DeGolier.... & 1,416 & 1,046 & 1,903 & 1,962 & 1,972 & Gas. \\
\hline & ..... do ... & ..... do.. & Federal Land Bank & Belmont... & 1,430 & 1,056 & 1,918 & 1,979 & 1,992 & Do. \\
\hline & ..... do & ..... do . & Gardner & $\ldots$ do ........... & 1,273 & 904 & 1,728 & 1,815 & 1,828 & Do. \\
\hline & ..... do... & ......do_. & Olezewski No.2. & Wittmer.... & 1,219 & 835 & 1,711 & 1,764 & 1,774 & Do. \\
\hline 34. & do.... do & ..... do & Olezewski No. 3 & Tri-State... & 1,251 & 874 & 1,721 & 1,791 & 1,803 & Do. \\
\hline 35. & do & .......do do & Olezewski No.1... & Wittmer.... & 1,223 & 849 & 1,702 & $\begin{array}{l}1.759 \\
\text { 1. }\end{array}$ & 1,769 & Do. \\
\hline & $\ldots$.... do ... & .....do... & Wyss ................. & DeGolier & 1,221 & 840 & 1,698 & 1,758 & 1,800 & Do. \\
\hline & .... do . & ..... do & Hayes......... & Belmont.......... & 1,232 & 830 & 1, 698 & 1,761 & 1,778 & Do. \\
\hline $38 \ldots$ & .....do.. & do & Casper & ..... do ...... & 1,199 & 830 & 1,670 & 1,739 & 1,755 & Do. \\
\hline $39 \ldots$ & ..... do . & ..... do & Lent & do do ........ & 1,186 & 795 & 1,662 & 1,721 & 1,729 & Do. \\
\hline & .... do ... & ..... do & Look.... & Pentoga & 1,183 & 795 & 1,657 & 1,719 & 1,785 & Do. \\
\hline $41 \ldots$ & .....do.. & .... do & Hoover...... & Belmont .... & 1,127 & 736 & 1,570 & 1,670 & 1,682 & Do. \\
\hline & ando & ........ do & Andrews.. & Huron......... & 1,126 & 740 & 1,604 & 1,672 & 1,685 & Do. \\
\hline
\end{tabular}

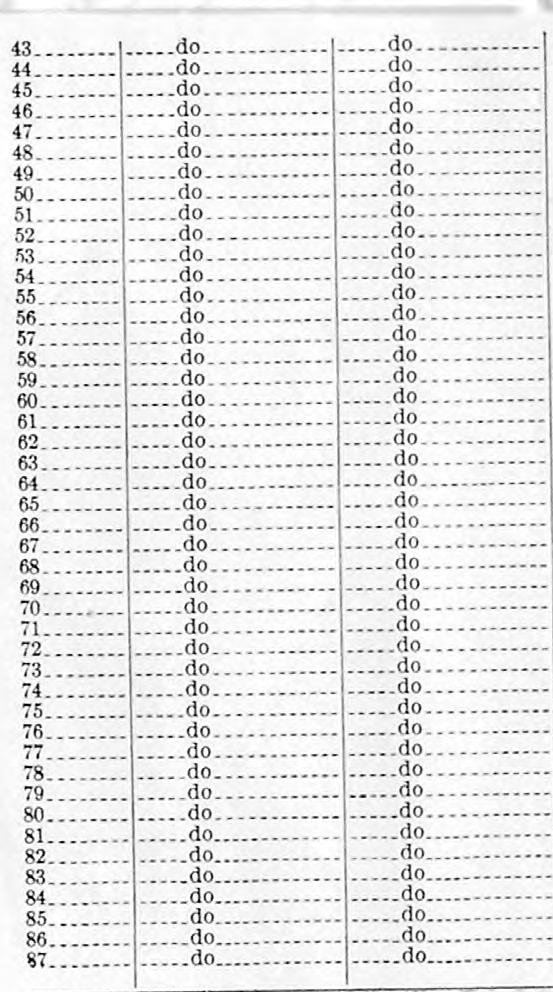

\begin{tabular}{|c|c|}
\hline & \\
\hline Cros & Lycoming \\
\hline Brown.. & Parmer Smith \\
\hline Norris.- & Tri-State \\
\hline $\begin{array}{l}\text { ordon.. } \\
\text { lark... }\end{array}$ & Crescent Production \\
\hline $\begin{array}{l}\text { lark.... } \\
\text { umsey. }\end{array}$ & $\begin{array}{l}\text { Burns Oil \& } \mathrm{G} \\
\text { Belmont....... }\end{array}$ \\
\hline inach... & .... do ..... \\
\hline 0.1 & \\
\hline os & Lamoka \\
\hline ding & Belmont . \\
\hline Faucett. & Lamoka. \\
\hline Dist & $\ldots$ do $\ldots .$. \\
\hline De & Cunningha \\
\hline Rud & Williamspor \\
\hline Deu & $\begin{array}{l}\text { Belmont } \\
\text { Williamsport Oi }\end{array}$ \\
\hline Deusenberg $\mathrm{N}$ & minatisport o \\
\hline $\begin{array}{l}\text { Ardry } \\
\text { Willis....... }\end{array}$ & Belmont... \\
\hline $\begin{array}{l}\text { Wi } \\
\text { Ru }\end{array}$ & J. Carpenter \\
\hline Spr & Belmont.... \\
\hline Suderski. & ..... do ... \\
\hline $\begin{array}{l}\text { Deming - } \\
\text { Waddell. }\end{array}$ & ..... do do \\
\hline J. Galek... & $\ldots . .$. do $\ldots . .$. \\
\hline M. Galek. & \\
\hline $\begin{array}{l}\text { S. Allen } \\
\text { Pulyer No }\end{array}$ & Salt ... \\
\hline No. 1 - & Belmont . \\
\hline $\begin{array}{l}\text { or No. } 2 \text {. } \\
\text { is }\end{array}$ & ..... do ..... \\
\hline $\begin{array}{l}\text { Travi } \\
\text { Littee }\end{array}$ & ..... do..... \\
\hline Walton. & J. Carpenter.... \\
\hline ey & Belmont....... \\
\hline . & do do......... \\
\hline & $\ldots$ do ..... \\
\hline $\mathrm{d}$ & J. Carpenter ......... \\
\hline andra.. & Belmont.... \\
\hline $\begin{array}{l}\text { Pric } \\
\text { Litt }\end{array}$ & .................. \\
\hline E. Losey..... & 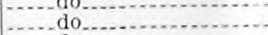 \\
\hline $\begin{array}{l}\text { Glenn.... } \\
\text { Kelly }\end{array}$ & do. \\
\hline ar.-.- & ..... do \\
\hline
\end{tabular}

\begin{tabular}{|c|c|c|c|c|c|}
\hline 1,167 & 797 & 1,660 & 1,732 & 1,741 & Do. \\
\hline $\begin{array}{l}1,141 \\
1,113\end{array}$ & 780 & 1,647 & 1,703 & 1,718 & Do. \\
\hline $\begin{array}{l}1,113 \\
1,124\end{array}$ & 756 & 1,626 & 1,696 & 1,740 & Salt water. \\
\hline $\begin{array}{l}1,124 \\
1,117\end{array}$ & $\begin{array}{l}630 \\
730\end{array}$ & $\begin{array}{l}1,602 \\
1,606\end{array}$ & 1,674 & $\begin{array}{l}1,683 \\
1,800\end{array}$ & Gas. \\
\hline 1,117 & 754 & $\begin{array}{l}1,606 \\
1,630\end{array}$ & $\begin{array}{l}1,681 \\
1,720\end{array}$ & $\begin{array}{l}1,800 \\
1,734\end{array}$ & Salt water. \\
\hline 1,158 & 768 & 1,625 & 1,705 & 1,717 & Gas. \\
\hline $\begin{array}{l}1,261 \\
1,274\end{array}$ & 868 & 1,752 & 1,817 & 1,830 & Do. \\
\hline $\begin{array}{l}1,274 \\
1,371\end{array}$ & 868 & 1,737 & 1,812 & 1,826 & Do. \\
\hline $\begin{array}{l}1,371 \\
1,353\end{array}$ & 955 & 1,836 & 1,913 & 1,926 & Do. \\
\hline 1,353 & 943 & 1,797 & 1,896 & 1,935 & Do. \\
\hline $\begin{array}{l}1,328 \\
1,325\end{array}$ & 924 & 1,792 & 1,878 & 1,885 & Do. \\
\hline $\begin{array}{l}1,325 \\
1,464\end{array}$ & 940 & 1,803 & 1,887 & 1,907 & \\
\hline $\begin{array}{l}1,464 \\
1,286\end{array}$ & 1,135 & 2,035 & 2,108 & 2,114 & Salt water. \\
\hline $\begin{array}{l}1,286 \\
1,269\end{array}$ & 879 & 1,759 & 1,838 & 1,874 & Gas. \\
\hline $\begin{array}{l}1,269 \\
1,223\end{array}$ & 860 & 1,750 & 1,819 & $\begin{array}{l}1,832 \\
785\end{array}$ & $\begin{array}{l}\text { Do. } \\
\text { Do. }\end{array}$ \\
\hline $\begin{array}{l}1,223 \\
1,238\end{array}$ & $\begin{array}{l}807 \\
830\end{array}$ & $\begin{array}{l}1,665 \\
1,764\end{array}$ & $\begin{array}{l}1,77 \\
1,795\end{array}$ & $\begin{array}{l}1,180 \\
1,805\end{array}$ & Do. \\
\hline $\begin{array}{l}1,208 \\
1,225\end{array}$ & 825 & 1,722 & 1,787 & 1,804 & Do. \\
\hline 1,277 & 863 & 1,725 & 1,828 & 1,845 & Do. \\
\hline 1,161 & 755 & 1,610 & 1,717 & 1,728 & Do. \\
\hline 1,304 & 889 & 1,750 & 1,846 & 1,867 & Do. \\
\hline 1,489 & 1,083 & 1,939 & 2,038 & 2,053 & Do. \\
\hline 1,504 & 1,105 & 1,993 & 2,064 & 2,077 & Do. \\
\hline 1,525 & 1,122 & 1,992 & 2,085 & 2,098 & Do. \\
\hline 1,538 & 1,138 & 1,997 & 2,102 & 2,117 & Do. \\
\hline 1,519 & 1,124 & 1,991 & 2,092 & 2,111 & Do. \\
\hline 1,504 & 1,100 & 1.977 & 2,085 & 2,090 & Do. \\
\hline 1,479 & 1,095 & 1,941 & 2,041 & 2,052 & Do. \\
\hline 1,506 & 1,051 & 1,963 & 2,075 & 2,082 & Do. \\
\hline 1,535 & 1,157 & 2,016 & 2,125 & 2,154 & Do. \\
\hline 1,447 & 1,080 & 1,941 & 2,044 & 2,056 & Do. \\
\hline 1,434 & 1,030 & 1,890 & 2,004 & 2,018 & Do. \\
\hline 1,471 & 1,086 & 1,963 & 2,057 & 2,119 & Do. \\
\hline 1,462 & 1,060 & 1,947 & 2,044 & 2,070 & Do. \\
\hline 1,408 & 1,045 & 1,900 & 2,002 & 2,016 & Do. \\
\hline 1,312 & 984 & 1,862 & 1,957 & 1,965 & Do. \\
\hline 1,388 & 1,076 & 1,956 & 2,060 & 2,082 & Salt water. \\
\hline 1,528 & 1,194 & 2. 082 & 2,177 & 2,194 & Gas. \\
\hline 1,521 & 1,190 & 2,085 & 2,186 & 2,186 & Salt water. \\
\hline 1,582 & 1,215 & 2,094 & 2,187 & 2,201 & Gas, \\
\hline 1,532 & 1,168 & 2,053 & 2,134 & 2,153 & Do. \\
\hline 1,553 & 1,182 & 2,061 & 2,150 & $\begin{array}{l}2,165 \\
2,129\end{array}$ & $\begin{array}{l}\text { Do. } \\
\text { Do. }\end{array}$ \\
\hline $\begin{array}{l}1,499 \\
1,503\end{array}$ & $\begin{array}{l}1,145 \\
1,149\end{array}$ & $\begin{array}{l}2,026 \\
2,022\end{array}$ & $\begin{array}{l}2,115 \\
2,114\end{array}$ & $\begin{array}{l}2,129 \\
2,150\end{array}$ & Do. \\
\hline 1,203 & & & & & \\
\hline
\end{tabular}





\section{INDEX}

\begin{abstract}
Acknowledgments for aid......................

Allegany County, records of wells in......... 61-63

Altitudes on key horizons, measurement of ... $5-6$

A voca, dome near.

Bath quadrangle, fault in records of wells in

structure and gas possibilities in

Beech Hill, dome at.

Belmont Quadrangle Drilling Co.'s Coston

Bibliography No. 2 well, flow of

Canandaigua quadrangle, records of wells in..

Canaseraga quadrangle, records of wells in.... structure and gas possibilities in ...........

Canaseraga sandstone. See Dunkirk sandstone.
\end{abstract}

Cashaqua shale, change in lithology of....... 42-43 fault in .......... 31

key horizon in............................. 12-13

Chemung County, records of wells in......... 62

Columnar sections........................ 8, pl. 3

Convergence between Oriskany sandstone and surface rocks, features of $42-44$

Corning quadrangle, records of wells in structure and gas possibilities in

Deformation and deposition, significance of contemporaneous.

Drainage, relation of, to structure __ 44-45

Dundee, structure near........................ 58

Dundee gas field. See Wayne-Dundee gas field.

Dunkirk sandstone, bench at top of -..... 18, pl.4 convergence between Oriskany sandstone and.

identification of, in well cuttings.......... 27

key horizons in ............................. 17-18

section of

Earthquake, changes of sea floor in Bay of Sagami by

Elmira quadrangle, records of wells in structure and gas possibilities in

Extent and location of the area............ 3-4, pl. 1

Fall Creek Valley, fault in, evidence of........ 37-38

Faults, deformed zones along, interpretation of. 38-41

features of, by quadrangles................. 31-38

trend and form of ......................... 30-31

Fault zone on Purdy Creek, plastically deformed sediments in $37, \mathrm{pl} .4$
Field work and personnel.................... 4-6

Firtree Point, section near..................... 9-10

"Flagstone", definition of term................. 8

Folds, trend and form of

Fralich, Charles E., map contributed by....- 4

Gas, possible accumulations of.................. 45-59

Geneseo shale, section of ..................... 10

Genundewa limestone lentil, key horizon at_. 9-11

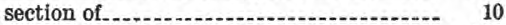

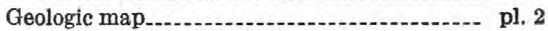

Gowanda shale and overlying beds, key horizons in sections of

Gowanda shale, deformed beds in ............ 34 significance of unconformity at horizon of. 42

Greenwood gas field, records of wells in ....... 63 structure and gas possibilities in........... 49-50

Greenwood quadrangle, faults in .............. 33-41 faults in, interpretation of deformed zones along . .

miscellaneous key horizons in............... 25-26

oil fields in ............................... 59

records of wells in . ........................ 61-62

section on hill in .......................... 25-26

structure and gas possibilities in .......... 48-51

Grimes sandstone, key horizon at_............ 14

Hamilton group, identification of formations of, in well cuttings................... 27

stratigraphy of .......................... 9

Hammondsport quadrangle, records of wells in

structure and gas possibilities in

Hatch shale, stratigraphic position of ......... 13-14

Hornell, domes near.............................. 56-57

Hornell quadrangle, faults in ................ 33-41

faults in, interpretation of deformed zones

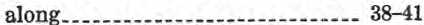

yecords of wells in ....................... 61

structure and gas possibilities in .......... 56-57

Independence, dome near....................... 47-48

Jasper, dome near ............................. 51-52

Joints, trend and form of .................... 30

Keuka Lake, key horizon in flagstone stratum on

Key horizons, features of .................... 8-26 measurement of altitudes on.............. $\quad 5-6$

Lithologic units, nomenclature and correlation of

Location and extent of the area Ludlowville shale, Tichenor limestone member of, key horizon on 
Marcellus shale, gas in

identification of, in well cuttings...........

Menteth limestone, key horizon on............

Montour Falls, domes near.

Middlesex shale, key horizons in.

Moscow shale, Menteth limestone member of, key horizon on

Naples quadrangle, structure and gas possibilities in.

Nunda sandstone, key horizons in .............

Oil, possible occurrence of

Onondaga limestone, depth to top of, in wells. gas in identification of, in well cuttings......... variations in thickness of.

Ontario County, records of wells in............ Oriskany sandstone, convergence between surface rocks and

depth to top of, in wells. $42-44$

displacement of, by fault

occurrence and character of.

records of wells to

28

relation of structural features in, to those

in Tully limestone

subsurface faults above, dying out of .....- 41-42 variations in thickness of ............. 46

Ovid quadrangle, faults in $31-32$ records of wells in structure and gas possibilities in

Parrish limestone lentil, horizon of stratigraphic position of

Penn Yan quadrangle, records of wells in structure and gas possibilities in

Personnel and field work

Phelns quadrangle, records of wells in structure and gas possibilities in

Pipe Creek shale member, key horizon on stratigraphic position and lithologic character of

Pleistocene deposits, bedrock covered by .....

Post Creek, dome near.

Public Works Administration, allotment of funds by

Purdy Creek Valley, faults in $36-37$,

Quadrangles, faults described by list of, shown on plate 2 .

Rhinestreet shale, convergence between Oriskany sandstone and.

displacement of, by fault. (2) key horizon at

Rock Stream flagstone, displacement of, by fault key horizon at.

32,33

\section{Sene}

Seneca County, record of well in

Schuyler County, records of wells in

Slate Creek fault, features of................ 34-36

interpretation of deformed zone along..... 39-41

Springwater, structural terrace near......... 57-58

Standish flagstone, change in lithology of ..... 42-43

key horizons in

State Line gas field, records of wells in New

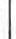

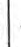

Tichenor limestone, key horizon on ......... 8

Tully limestone, depth to top of, in wells....- 60-65

displacement of, by fault................ 34, 37

identification of, in well cuttings........... $\quad 27$

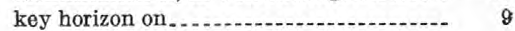

relation of structural feetures in, to those in Oriskany sandstone.......... 27

Watkins, domes near............................. 53-54

Watkins quadrangle, faults in .

records of wells in................. $60-61$

structure and gas possibilities in

Wayland quadrangle, structure and gas possi-

bilities in................ 57-58

Wayne-Dundee gas field, records of wells in ... 64-65

structure and gas possibilities in ........... 54-56

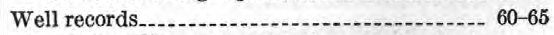

Wellsville quadrangle, miscellaneous key hori-

zons in...................... 25

oil possibilities in

records of wells in.......................... 61

structure and gas possibilities in

West Hill formation, key horizon in .......... 14-15

West River shale, section of............... 9

stratigraphic relations of

Whitesville, domes near.................... 48

oil possibilities near........................ 59

Wiscoy sandstone, key horizons in

lithologic character of

Woodhull dome, features of................. 51

Woodhull quadrangle, miscellaneous key horizon in . 25

records of wells in . .

structure and gas possibilities in

Yates County, geologic map of ................. pl.2 records of wells in .......... 60,6 


\title{
GE0L0GIC STRUCTURE AND 0CCURRENCE OF GAS IN PART OF SOUTHWESTERN NEW YORK
}

\section{PART 2. SUBSURFACE STRUCTURE IN PART OF SOUTH- WESTERN NEW YORK AND MODE OF OCCURRENCE OF GAS IN THE MEDINA GROUP}

\author{
By G. B. RICHARDSON
}

\section{ABSTRACT}

Based on the records of several hundred deep wells, contour maps have been prepared showing the monoclinal structure of part of western New York, and isopach lines have been drawn showing the westward convergence of the rocks. The mode of occurrence of natural gas in the Medina group is briefly discussed. The location of the gas fields has not been determined by structural traps, but rather stratigraphy and lithology are the controlling factors in trapping the gas, which occurs in porous lenses and streaks of sandstone sealed within impermeable beds. This mode of occurrences of the Medina gas makes the search for new fields in western New York more hazardous than in most natural gas regions. As structure has not formed traps for the gas there is no surface guide to favorable sites for testing, and new fields are found by haphazard drilling. It would be helpful, however, when wells are sunk, to study the lithology of the gas-bearing zone by an examination of the drill cuttings and core samples of the sand and to have electrical logs made of the wells to obtain measurements of permeability and porosity. Such tests may indicate the direction of greatest porosity in which the sand is more likely to contain gas.

\section{INTRODUCTIÓN}

The records of several hundred deep wells were obtained in 1934 in connection with an investigation by the Geological Survey to determine the geologic structure in the general region of the Oriskany gas fields of south-central New York. ${ }^{1}$ This investigation was financed with funds provided by the Federal Emergency Administration of Public Works. The well records were supplemented in 1935 by logs of selected wells that had been sunk in search of gas in the Medina fields in the western part of the State. With this information as a basis the accompanying maps (pls. 5-8) have been prepared showing the subsurface structure in part of western New York, the convergence

\footnotetext{
1 Bradley, W. H., and Pepper, J. F., Structure and gas possibilities of the Oriskany sandstone in Steuben, Yates, and parts of the adjacent counties, New York: U. S. Geol. Survey Bull. 899-A, pp. 1-68, 1938.
} 

UNITED STATES DEPARTMENT OF THE INTERIOR

Harold L. Ickes, Secretary

GEOLOGICAL SURVEY

W. C. Mendenhall, Director

Bulletin 899-B

\title{
GEOLOGIC STRUCTURE AND OCCURRENCE OF GAS IN PART OF SOUTHWESTERN \\ NEW YORK
}

\author{
Part 2. SUBSURFACE STRUCTURE \\ IN PART OF SOUTHWESTERN NEW YORK \\ AND MODE OF OCGURRENCE OF GAS \\ IN THE MEDINA GROUP
}

BY

G. B. RICHARDSON

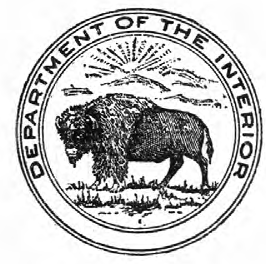

UNITED STATES

GOVERNMENT PRINTING OFFICE

WASHINGTON : 1941

For sale by the Superintendent of Documents, Washington, D. C. - . - . - . Price 30 cents 


\section{NOTE}

The Geological Survey in 1934, 1935, and 1936 studied the geologic structure and the occurrence of natural gas in the Oriskany and Medina sandstones in a large part of southwestern New York. The geologists have prepared separate reports on the areas for which they were responsible. However, as these areas are adjacent and form a real unit both geographically and geologically, the two reports are issued as parts of a single bulletin. No edition of the consolidated volume will be published, but the two parts may be bound together if desired. 


\section{CONTENTS}

Abstract . . .

Introduction . .

Stratigraphy

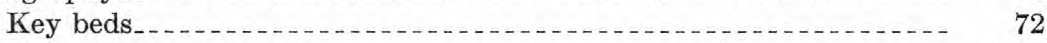

Convergence of strata. . . 73

Thickness of stratified rocks in the vicinity of Olean

Structure

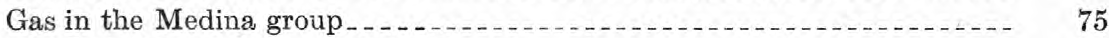

Relation of gas to structure

Relation of gas to lithology _... 75

Well records ............

\section{ILLUSTRATIONS}

Prate 5. Map of southwestern New York showing location of wells.......

Page

72

6. Map showing isopach lines that represent intervals between the top of the Medina group and the top of the Onondaga limestone and between the top of the Onondaga limestone and the top of

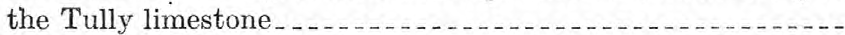

7. Map showing by contour lines drawn on the top of the Onondaga limestone the subsurface structure in part of southwestern New York, approximate outlines of principal gas-producing areas, and location of selected wells _........................

8. Map showing structure contour lines drawn on the top of the Medina group and location of selected gas wells and dry holes in part of Erie County 

of the strata, and the relation of the occurrence of natural gas to geologic structure in part of Erie County. •

The logs of the wells were obtained from many sources. For courteously supplying records and other information the writer is under obligation to the following organizations and individuals:

Belmont Quadrangle Drilling Corporation, F. M. Brewster and J. A. Thompson; Godfrey L. Cabot, Inc., C. D. Whorton; Empire Gas \& Fuel Co., G. Holbrook and C. T. Major; Finance Oil \& Gas Co., Thomas Mills; Iroquois Gas Co., L. A. Brown and A. M. Nicholson; Keystone Gas Co., H. A. Wallace; Lycoming Producing Corporation, J. F. Robinson, U. F. Boyer, and F. H. Finn; New York State Museum and State Geological Survey, C. C. Adams, R. Ruedemann, D. H. Newland, and C. A. Hartnagel; New York State Oil Producers Association, N. Sullivan; North Penn Gas Co., J. Gaddess; Pavilion Natural Gas Co.; Penn-York Natural Gas Co., J. Reeves, H. E. Boyd, and N. C. Davies; Republic Light, Heat \& Power Co., S. B. Severson and G. M. Merrill; Rochester Gas \& Electric Co., A. M. Beebe and L. H. East; Solvay Process Co., R. H. Perkins and W. C. Phalen; Torrey, Fralich \& Simmons, C. E. Fralich, A. C. Simmons, and W. H. Young; University of Rochester, H. L. Alling; and G. H. Chadwick, of Catskill, F. L. Dougherty, of Dunkirk, H. H. Cranston, of Fredonia, and S. T. Lockwood, of Buffalo.

\section{STRATIGRAPHY}

The generalized stratigraphic sequence in central and western New York is shown in the accompanying section, after Newland and Hartnagel and Goldring, of the State Museum. ${ }^{2}$ The section shows the stratigraphic position of the principal gas-producing zones and of the key beds reported in the driller's logs of wells. The stratigraphic nomenclature used in the present report follows that given in the section and also follows current usage in the gas fields of western New York. The Medina group as thus used is assigned entirely to the Silurian. The strata here designated Oswego and Queenston in the lower part of the group have been correlated with formations elsewhere that are assigned an Ordovician age in other reports of the Federal Geological Survey.

${ }^{2}$ Newland, D. H., and Hartnagel, C. A., Review of the natural gas and petroleum developments in New York State: New York State Mus. Bull. 295, pp. 106-107, 1932. Goldring, Winifred, Handbook of paleontology for beginners and amateurs; Part 2, The formations: New York State Museum Handbook 10, pp. 190-191, 1931. 
Generalized geologic section in central and western New York

[Chiefly after D. H. Newland, C. A. Hartnagel, and Winifred Goldring]

\begin{tabular}{|c|c|c|c|}
\hline System or series & Group or formation & Description & $\underset{\text { (feet) }}{\text { Thickness }}$ \\
\hline \multirow[t]{2}{*}{ Pennsylvanian. } & Olean. & $\begin{array}{l}\text { Coarse conglomerate with well-rounded peb- } \\
\text { bles mostly of vein quartz. Texture changes } \\
\text { rapidly both horizontally and vertically into } \\
\text { coarse white sandstone. }\end{array}$ & $60-70$ \\
\hline & Unconformity. & $\begin{array}{l}\text { Absence of Mauch Chunk and associated } \\
\text { formations. }\end{array}$ & \\
\hline \multirow{3}{*}{$\begin{array}{l}\text { Mississippian or Up- } \\
\text { per Devonian. }\end{array}$} & Knapp. & Conglomerate and interbedded shale. & $60-105$ \\
\hline & Oswayo. & $\begin{array}{l}\text { Fossiliferous olive-green and rust-colored } \\
\text { limonitic shales. Two-foot bed of very } \\
\text { fossiliferous limestone near base. Probably } \\
\text { small unconformity between Oswayo and } \\
\text { Cattaraugus. A few thin beds of sandstone. }\end{array}$ & $160-250$ \\
\hline & Cattaraugus. & $\begin{array}{l}\text { Bright-red shales with interbedded green or } \\
\text { bluish shales and fine-grained micaceous } \\
\text { sandstones. Local beds of conglomerate } \\
\text { characterize the formation. At base is Wolf } \\
\text { Creek conglomerate. Conglomerates of } \\
\text { Cattaraugus beds have flat or discoidal } \\
\text { pebbles, some of jasper, distinguishing them } \\
\text { from Olean. }\end{array}$ & $300-350$ \\
\hline \multirow{8}{*}{ Devonian. } & Chemung. & $\begin{array}{l}\text { Gray, olive, and bluish shales, some dark } \\
\text { purple or chocolate color. Many thin beds } \\
\text { of argillaceous sandstone. Lower half of } \\
\text { Chemung contains the oil-producing sands } \\
\text { of the State. }\end{array}$ & $1,200-1,500$ \\
\hline & Portage. & $\begin{array}{l}\text { Sandstone, flags, and black carbonaceous } \\
\text { shales. Has gas-bearing strata. }\end{array}$ & $1,200-1,400$ \\
\hline & Genesee. & Black shale. & $25-50$ \\
\hline & Tully. & Gray limestone. & $0-30$ \\
\hline & Hamilton. & $\begin{array}{l}\text { Blue, gray, and olive shales. Basal portion, } \\
\text { Marcellus black shale, which is gas-bearing. }\end{array}$ & $600-700$ \\
\hline & Onondaga. & $\begin{array}{l}\text { A heavy bedded limestone, the "flint" of the } \\
\text { drillers. Gas-bearing. }\end{array}$ & $60-130$ \\
\hline & Oriskany. & $\begin{array}{l}\text { Sandstone. Gas-bearing in Schuyler, Yates, } \\
\text { Steuben, and Allegany Counties. }\end{array}$ & $0-20$ \\
\hline & Unconformity. & Absence of Helderbergian formations. & \\
\hline \multirow{4}{*}{ Silurian. } & Salina. & $\begin{array}{l}\text { A series of water limes, gypseous shales, beds } \\
\text { of anhydrite and gypsum, rock salt. Red } \\
\text { shales at base. Upper portion of series gas } \\
\text { bearing. }\end{array}$ & $700-800$ \\
\hline & Niagara. & $\begin{array}{l}\text { Heavy bedded dolomites, Lockport and } \\
\text { Guelph. Rochester shale at base is of } \\
\text { Clinton age but usually logged with Niagara. } \\
\text { Gas in Seneca and Ontario Counties. } \\
\end{array}$ & 200 \\
\hline & Clinton. & Limestones, shales, with thin bed of hematite. & $30-150$ \\
\hline & Medina. & $\begin{array}{l}\text { Upper } 150 \text { feet white and red sandstones } \\
\text { (Albion). Most prolific gas horizon in State. } \\
\text { Main mass red shale (Queenston); white } \\
\text { Oswego sandstone at base. }\end{array}$ & $1,100-1,200$ \\
\hline \multirow{3}{*}{ Ordovician. } & $\begin{array}{l}\text { Lorraine, or "Hudson } \\
\text { River," and Utica. }\end{array}$ & $\begin{array}{l}\text { A series of alternating beds of sandstones and } \\
\text { shales. At base is Utica black shale. }\end{array}$ & $500-600$ \\
\hline & Trenton. & $\begin{array}{l}\text { Alternating dark limestones and shales. Pro- } \\
\text { ductive in Onondaga, Oswego, Oneida, and } \\
\text { Lewis Counties. Many large gas pockets. }\end{array}$ & $700-900$ \\
\hline & $\begin{array}{l}\text { Tribes Hill and Little } \\
\text { Falls. }\end{array}$ & $\begin{array}{l}\text { Heavy bedded limestones. Also known as the } \\
\text { "Calciferous" formation. Basal beds in part } \\
\text { belong to the Cambrian, the boundary being } \\
\text { indefinite. }\end{array}$ & $100-140$ \\
\hline Cambrian. & Potsdam. & $\begin{array}{l}\text { A sandstone where present directly over- } \\
\text { lying the pre-Cambrian. Reported in a few } \\
\text { deep wells in western New York. Gas in } \\
\text { one or two wells in central New York. }\end{array}$ & $10-50$ \\
\hline Pre-Cambrian. & & $\begin{array}{l}\text { Reported in several wells in western and } \\
\text { central New York. }\end{array}$ & \\
\hline
\end{tabular}




\section{KEY BEDS}

The logs of wells as reported by the drillers in general show only a few readily recognizable or key beds. (See list of wells, pp. 79-91.) One of the most useful of these beds for determining the stratigraphy and structure is the Onondaga limestone, of Middle Devonian age, which is widely distributed and readily recognized by well drillers. It immediately underlies the black Marcellus shale and overlies the Oriskany sandstone where that is present. The Onondaga is a massive gray cherty linestone ranging from less than 50 to more than 150 feet in thickness and is reported as "flint" by the drillers. It crops out, commonly forming an escarpment, from Lake Erie in the vicinity of Buffalo to the Hudson Valley in the vicinity of Albany and extends southward into Pennsylvania. In New York the Onondaga is a persistent limestone, though locally it is somewhat shaly in its upper part.

The Oriskany sandstone lying at the base of the Devonian system in western New York was deposited in irregular thickness in a sea transgressing the eroded surface of an old land mass. It locally disappears, yet it is apparently more continuous as a sheet deposit than the lenticular beds of sandstone that constitute some of the oil and gas reservoirs of Upper Devonian age. The type locality of the Oriskany is at Oriskany Falls, Oneida County, N. Y., where it is a light-gray fossiliferous coarse-grained quartz sandstone about 20 feet thick. The Oriskany sandstone is of economic importance because of the occurrence in it of large quantities of natural gas. The structure and gas possibilities of the Oriskany in a part of the State are discussed by Bradley and Pepper in part 1 of this bulletin. ${ }^{3}$ Numerous well records show the occurrence of the Oriskany sandstone in central New York. The approximate northwestern limit of its occurrence underground, as indicated by the records of wells drilled before 1936, is shown on plate 5 .

Another important key bed is the Tully limestone, lying at the base of the Upper Devonian series, between the overlying Genesee black shale and dark shale in the uppermost part of the Hamilton group. It apparently does not underlie so large an area as the Onondaga limestone, but recent drilling shows that it has a greater extent than was formerly realized. The Tully limestone crops out in the Finger Lake region of central New York and extends into Pennsylvania, where its outcrop has recently been observed in the central part of the State. ${ }^{4}$ In New York the Tully is a massive gray limestone as much as 30 feet thick.

The key horizon that serves as a marker for the gas-bearing beds of Medina age (see p. 71) is designated by drillers as the "top of the

\footnotetext{
${ }^{3}$ Bradley, W. H., and Pepper, J. F., op. cit.

"Willard, Bradford, A Tully limestone outcrop in Pennsylvania: Pennsylvania Acad. Sci. Proc., vol. 8, pp. 57-62, 1934.
} 


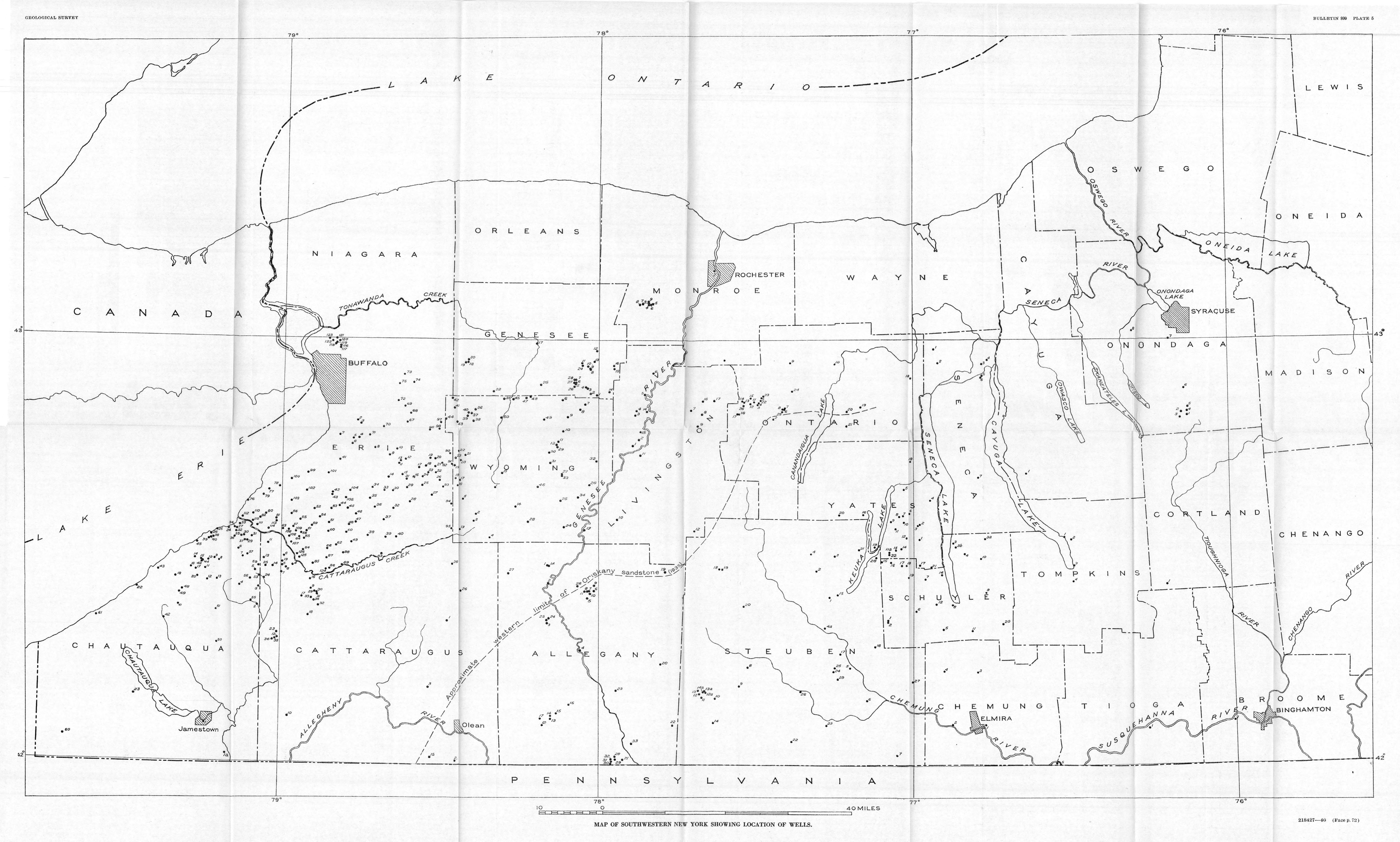




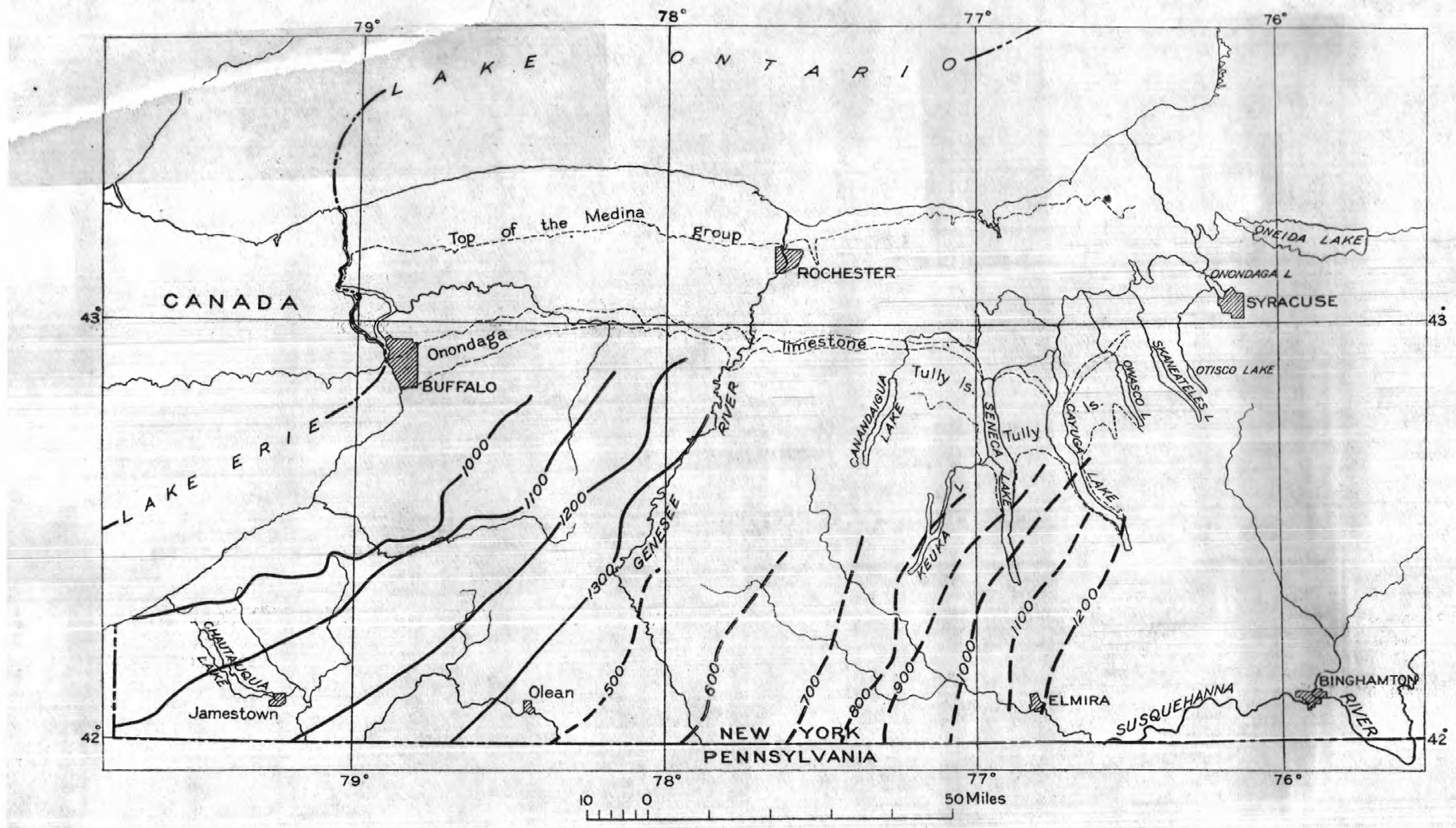

MAP SHOWING ISOPACH LINES THAT REPRESENT INTERVALS BETWEEN THE TOP OF THE MEDINA GROUP AND THE TOP OF THE ONONDAGA LIMESTONE (SHOWN BY SOLID LINES) AND BETWEEN THE TOP OF THE ONONDAGA LIMESTONE AND THE TOP OF THE TULLY LIMESTONE (SHOWN BY BROKEN LINES).

Location of outcrop of top of Medina group and outcrop of Onondaga and Tully limestones from Geologic map of New York by New York State Museum. 

Red Medina." This marks the change from gray shale in the lower part of beds of Clinton age to an underlying bed of sandstone that despite the drillers' term "Red Medina," is not everywhere red. In places this sandstone beneath the Clinton is the so-called Gray band or Thorold sandstone, which averages only about 5 feet in thickness. The age of the Gray band, whether Clinton or Medina, is doubtful, though the New York State Museum ${ }^{5}$ now includes it in the Clinton. The Gray band seems to be locally absent where shale in the Clinton is reported to lie directly on red sandstone at the top of the Albion sandstone of the Medina group.

\section{CONVERGENCE OF STRATA}

Measurement of the stratigraphic intervals between the key beds reported in the records of the wells shows clearly the convergence of the strata. The rocks constitute a great wedge of sediments that decrease in thickness from east to west. The intervals between the top of the Medina group and the top of the Onondaga limestone and between the tops of the Onondaga and Tully limestones are shown by isopach lines on plate 6 .

The Onondaga-Tully interval decreases from 1,700 feet in the vicinity of Owego, Tioga County, to 500 feet in the vicinity of Portville, Cattaraugus County, at the rate of about 13 feet per mile. The Onondaga-Medina interval decreases from 2,500 feet in the vicinity of Ludlowville, Tompkins County, to 1,400 feet in the vicinity of Livonia, Livingston County, at the rate of about 22 feet per mile, and from more than 1,500 feet in eastern Allegany County to less than 1,000 feet in western Erie County, at the rate of about 11 feet per mile. These isopach lines are based on scattered measurements and are necessarily generalized.

Relatively few measurements have been published showing the convergence in the beds above the Tully limestone, but an indication of conditions is afforded by rough measurements at two places of the interval between the Onondaga limestone and the Dunkirk shale, a formation in the Upper Devonian series. Near Dunkirk, Chautauqua County, that interval as shown by well records is about 800 feet, and in the vicinity of Woodhull, Steuben County, where the Dunkirk shale has become the Dunkirk sandstone, the interval between the base of the Dunkirk and the Onondaga limestone in a deep well, Steuben County No. 22, is about 4,000 feet, indicating a convergence of about 3,200 feet in a distance of a little more than 100 miles.

\section{THICKNESS OF STRATIFIED ROCKS IN THE VICINITY OF OLEAN}

One of the results of the recent deep drilling has been to permit a closer estimate than heretofore has been possible of the thickness of the rocks between the Olean conglomerate member of the Pottsville 
formation, of Pennsylvanian age, and rocks of pre-Cambrian age. The well on the Quinlan farm located 5 miles south of Olean (Cattaraugus County well No. 2, p. 80), drilled in 1933, was started about 600 feet below the Olean conglomerate and reached the top of the Onondaga limestone at a depth of 4,188 feet. At this location the isopach lines show an interval of about 1,450 feet between the top of the Onondaga limestone and the top of the Medina group (pl. 6) and, assuming that the Medina-pre-Cambrian interval is at least as much as that at Rochester-2,847 feet-(Monroe County well No. 2 ), a thickness of about 9,085 feet between the Olean conglomerate and the pre-Cambrian rocks in the vicinity of Olean is indicated.

\section{STRUCTURE}

That part of New York State lying south of Lake Ontario and west of the escarpment of the Catskill Mountains is in the northern part of the Appalachian synclinorium. This trough lies between the Allegheny Front and the Cincinnati arch and at the northeast rises on the flank of the Adirondack dome. Northwestward from the Allegheny Front, which marks the western border of the zone of closely folded rocks of the Appalachian province, the folds decrease in steepness and gradually fade away in irregular wrinkles. Locally the rocks are faulted. Farther northwestward the beds form a monoclinal slope on the flank of the Cincinnati arch, and north of Lake Ontario the strata rise to the Laurentian Shield.

In western New York on the northwestern flank of the Appalachian synclinorium, where the structure is monoclinal, the well records (pp. 79-91) are sufficiently numerous for structure contours to be drawn on the top of the Onondaga limestone at intervals of 100 feet, as shown on plate 7 . These show that the strata dip east of south at an average rate of 40 to 50 feet to the mile. The Onondaga limestone along its outcrop in the western part of the State ranges in altitude from 600 to 800 feet above sea level, and the contours show the area in which the dip carries the limestone down to a depth of 700 feet below sea level. Records of a few wells show that farther. south the Onondaga limestone lies as much as 1,700 feet below sea level in Chatauqua County and 3,400 feet below sea level in Broome County. These depths are due in part to folding and in part to the eastward thickening of the strata.

Structure contours drawn at intervals of 500 feet on the top of the Medina group and on the top of the Trenton limestone in central and western New York have recently been published by Hartnagel. ${ }^{6}$ In part of Erie County these Medina contours have been supplemented by the structure contours drawn at intervals of 50 feet on the top of the Medina group, as shown on plate 8. This map, which also shows

\footnotetext{
${ }^{6}$ Hartnagel, C. A., The Medina and the Trenton of western New York: Am. Assoc. Petroleum Geologists Bull, 22, pp. 79-99, 1938.
} 
the location of selected gas wells and dry holes, is based on data courteously supplied by L. A. Brown and A. M. Nicholson, of the Iroquois Gas Co., and by other companies. In the area where these contours have been drawn the structure is distinctly monoclinal. In places there is some irregularity in the trend and spacing of the contours, but there is no suggestion of closure.

\section{GAS IN THE MEDINA GROUP}

Natural gas occurs in New York in rocks of the Devonian, Silurian, and Ordovician systems, but the principal source for many years has been the Albion sandstone of lower Silurian age, the uppermost formation of the Medina group. The Medina gas occurs in several fields, chiefly in Chautauqua, Cattaraugus, Erie, Genesee, and Wyoming Counties, in wells of small capacity but long life. The gas fields have been discussed in publications by Bishop, Newland, and Hartnagel. ${ }^{7}$

The present writer in 1935 obtained a few facts concerning the mode of occurrence of the Medina gas that are here summarized.

\section{RELATION OF GAS TO STRUCTURE}

The Medina gas fields of western New York are localized on a monocline (see plate 7 ). The structure of a relatively small area of the gas-bearing rocks in part of Erie County is shown in more detail on plate 8 , on which structure contours are drawn on the top of the Medina group at intervals of 50 feet. Selected gas wells and dry holes are also shown. It is evident from the maps, which do not indicate any closure, that structure has not determined the localization of the natural gas, although presumably the monocline was effective in facilitating the migration of gas up the rise of the strata until it became trapped.

The monoclinal structure of the rocks in the Medina gas fields is in marked contrast to the structure in the Oriskany gas fields in southcentral New York and northwestern Pennsylvania. In those fields the gas occurs on structural highs along the axes of anticlines, the structure serving as a trap for the gas. ${ }^{8}$ In the Medina gas fields, on the contrary, the gas traps are porous lenses or streaks sealed by nonpermeable parts of the reservoir rock (pp. 77-78).

\section{RELATION OF GAS TO LITHOLOGY}

The Medina group crops out in a belt about 10 miles wide south of Lake Ontario, and the Albion sandstone, at the top of the group, is well

\footnotetext{
${ }^{7}$ Bishop, I. P., Report on petroleum and natural gas in western New York: New York State Geologist Ann. Rept. 17, pp. 9-63, 1899. Newland, D. H., The mineral resources of the State of New York: New York State Mus. Bulls. 223-224, pp. 165-197, 1921. Newland, D. H., and Hartnagel, C. A., Review of the natural gas and petroleum developments in New York State: New York State Mus. Bull. 295, pp. 101, 182, 1932: Recent natural gas developments in New York State: New York State Mus. Bull. 305, pp. 97-161, 1936. Harrnagel, C. A., The Medina and the Trenton of western New York: Am. Assoc. Petroleum Geologists Bull. 22, pp. 79-99, 1938.

${ }^{8}$ Bradley, W. H., and Pepper, J. F., op. cit.
} 
exposed in the gorge of the Niagara River. Dipping southward, in conformity with the regional structure, the Medina group extends underground far beyond the state boundary, and in southern Allegany County the gas sand lies more than 4,000 feet below sea level.

The Albion sandstone forms a sandy zone lying in the midst of a mass of shale. It is overlain by the Clinton formation and is underlain by the Queenston shale (see p. 71). The Albion sandstone consists of lenticular beds of red, gray, and white sandstone and interbedded red and gray shale somewhat more than 100 feet in thickness. The Whirlpool sandstone member, at the base of the formation, is the principal reservoir of natural gas. Although the Albion sandstone has been penetrated by many hundred drill holes put down in search of gas, very few detailed sections have been recorded. The following measurements are the most complete.

\section{Section of Albion sandstone, Niagara Gorge ${ }^{9}$}

Clinton formation:

Shale, gray.

Albion sandstone:

Feet

Sandstone, gray (Thorold sandstone member)

Sandstone, red and gray, cross-bedded _..................... 6

Sandstone, red, thin-bedded, and shale ...................... 20

Sandstone, gray, thick-bedded....... 4

Shale, reddish, and thin-bedded sandstone.

Sandstone, gray, thin-bedded _._.

Shale, blue-gray argillaceous or sandy

Sandstone, white, cross-bedded (Whirlpool sandstone member) _...... 22

Queenston shale:

Shale, red.

Section of Albion sandstone in a core drill hole at the Sterling salt mine, Cuylerville,

Clinton formation: Livingston County ${ }^{10}$

Shale, gray.

Albion sandstone:

Feet

Sandstone, gray

6. 8

Sandstone and shale, gray, green, and red.

4. 8

Shale, red and green

19. 7

Sandstone, shaly, red, brown, and gray-green 32.0

Shale, sandy, red, brown, and gray-green

Sandstone, white to brown

Shale, red, brown, and green

Sandstone, white to brownish

Not recorded........ 1.0

Sandstone, brown, red, green, and white 8.7

Sandstone, coarse, brown _.

100. 3

Queenston shale:

Shale, red.

' Kindle, E. M., and Taylor, F. B., U. S. Geol.'Survey, Geol. Atlas, Niagara folio (No. 190), p. 6, 1913.

10 Courtesy of International Salt Co. 


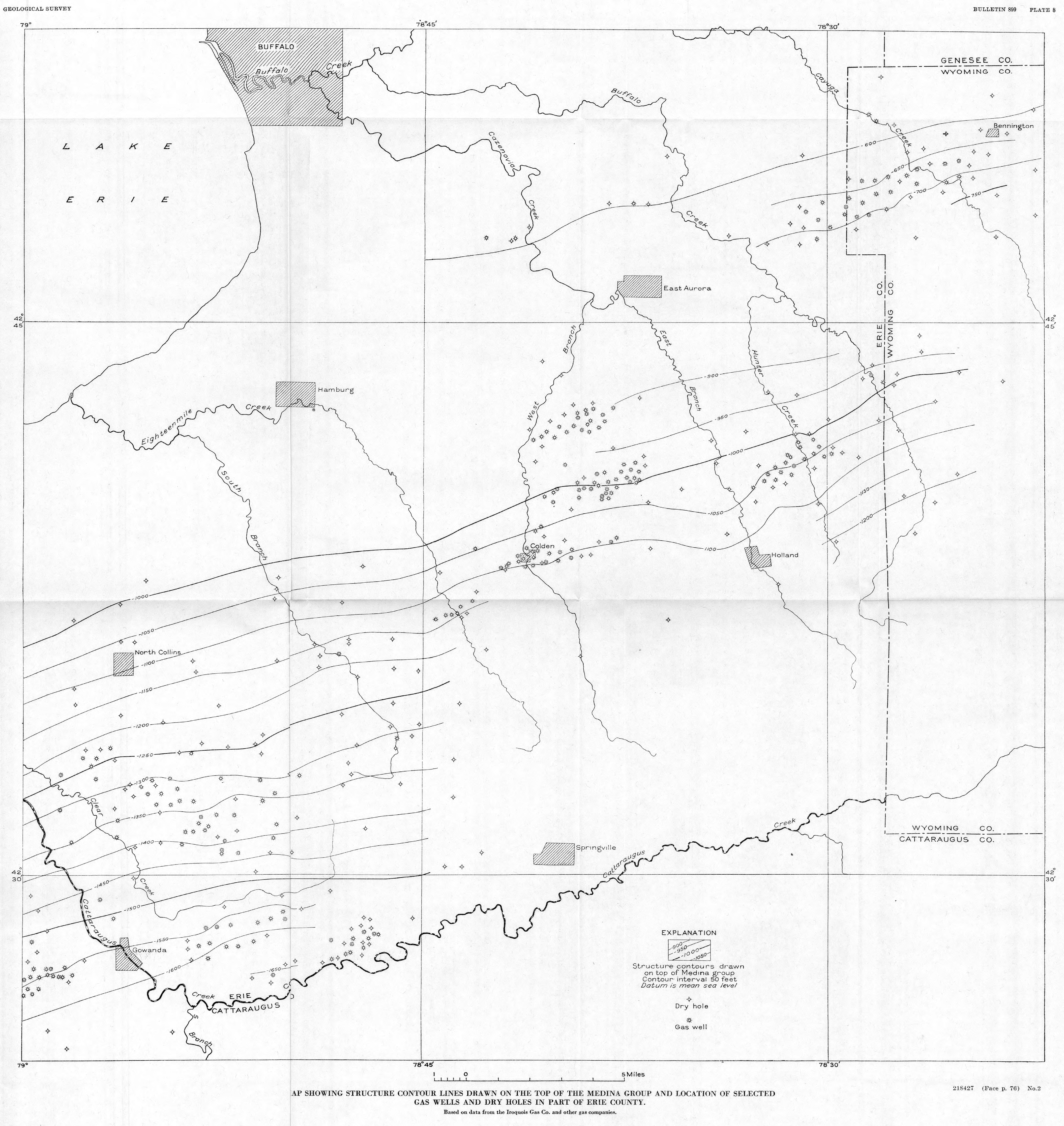


In the logs of wells as reported by drillers the Albion sandstone is subdivided into the White Medina sandstone (the Whirlpool sandstone member) at the base, the Red Medina sandstone and shale at the top, and an intervening shale "break." The following measurements selected at random from well drillers' records indicate the lenticularity and varying thicknesses of the subdivisions of the Albion sandstone in Erie County. The shale "break" and the White Medina locally disappear.

Measurements showing lenticularity of Albion sandstone in Erie County

[Thickness, in feet, as reported by well drillers]

\begin{tabular}{|c|c|c|c|c|c|c|c|c|c|c|c|c|c|c|c|c|c|c|c|c|c|}
\hline & A & B & C & $\mathrm{D}$ & $\mathrm{E}$ & $\mathrm{F}$ & G & $\mathrm{H}$ & I & $\mathrm{J}$ & $\mathrm{K}$ I & L & M & $N$ & 0 & $P$ & $Q$ & $\mathrm{R}$ & $\mathrm{S}$ & $T$ & U \\
\hline $\begin{array}{l}\text { lbion sandstone: } \\
\text { Red Medina sandstone } \\
\text { and shale, at top... } \\
\text { Shale "break" } \\
\text { White Medina sand- } \\
\text { stone, at base........ }\end{array}$ & $\begin{array}{l}80 \\
18 \\
20\end{array}$ & $\begin{array}{l}84 \\
15 \\
12\end{array}$ & $\begin{array}{r}98 \\
0 \\
0\end{array}$ & \begin{tabular}{c|}
80 \\
10 \\
20
\end{tabular} & $\begin{array}{r}120 \\
0 \\
0\end{array}$ & $\begin{array}{l}81 \\
14 \\
22\end{array}$ & $\begin{array}{r}83 \\
9 \\
18\end{array}$ & $\begin{array}{r}90 \\
3 \\
13\end{array}$ & \begin{tabular}{l|}
84 \\
12 \\
20
\end{tabular} & $\begin{array}{l}85 \\
26 \\
21\end{array}$ & \begin{tabular}{r|r}
82 \\
7 \\
26
\end{tabular} & \begin{tabular}{r|r}
65 \\
7 \\
32
\end{tabular} & $\begin{array}{r}100 \\
0 \\
0\end{array}$ & \begin{tabular}{r|}
85 \\
16 \\
8
\end{tabular} & $\begin{array}{r}97 \\
0\end{array}$ & $\begin{array}{l}85 \\
11\end{array}$ & $\begin{array}{l}81 \\
14 \\
20\end{array}$ & $\begin{array}{l}81 \\
10\end{array}$ & $\begin{array}{l}72 \\
10 \\
10\end{array}$ & \begin{tabular}{r|r}
98 \\
2 \\
14
\end{tabular} & $\begin{array}{r}80 \\
0 \\
0\end{array}$ \\
\hline
\end{tabular}

The White Medina, or Whirlpool, sandstone member of the Albion sandstone is indurated and fine-grained and is composed almost entirely of semirounded and subangular quartz grains of variable size, the maximum measured being less than 0.5 millimeter in diameter and the smallest less than 0.05 millimeter. A very subordinate amount of mica is present. The cement is chiefly secondary quartz, but locally it contains some calcite. The porosity and permeability of the sandstone are characteristically variable. The Albion sandstone as a whole, is generailly reported to yield little or no water, but in places salt water is present in small quantity.

Natural gas occurs at various horizons in the Albion sandstone, chiefly in the White Medina but also in places in the overlying Red Medina. There is locally a tendency toward a linear distribution of the gas reservoirs somewhat north of east, possibly parallel to the old shore line of the sea in which the sand grains were distributed and sorted.

Gas occurs irregularly in parts of the sandstone that are sufficiently porous to serve as a reservoir and is absent where the sandstone is practically impermeable or "tight" as described by well drillers. The presence of gas is characteristically erratic, dry holes being surrounded by gas wells and vice versa. The irregular distribution of the gas is shown also by new wells in which the gas is under relatively high pressure, adjacent to old wells in which the pressure has been much reduced. The gas-bearing rocks are not continuously permeable beds; if they were the gas would migrate up the slope of the monocline and escape along the outcrop. The reservoirs are in effect lenses and irregular streaks of porous sandstone enclosed by impermeable rock. Lenses of sandstone are traps for gas in places where the sandstone 
merges into shale. Traps for gas in beds of the Albion sandstone are caused also by the deposition of secondary quartz upon the original quartz grains so as to enclose porous lenses within the cemented, impermeable rock. Moreover, the distribution and relative abundance of the coarser and finer grains of which the sandstone is composed have locally formed traps. This is shown by the physical tests of samples of the White Medina sandstone tabulated below.

Two samples of the White Medina sandstone, shot from wells in Erie County, were tested by P. G. Nutting, of the United States Geological Survey with the results here shown. Sample A represents an unproductive sand in a dry hole and Sample B represents the pay streak in a commercial gas well. The differences in porosity and sand-grain distribution are striking. Fine grains, less than 0.052 millimeter in diameter, constitute more than 15 percent of the barren sand whose low porosity, less than 2 percent, is due to the abundance of the finest material, which is enough to prevent the occurrence of considerable voids in the rock; on the other hand the fines in the sample that represents a reservoir of natural gas are so few that voids remain unfilled and the porosity is more than 10 percent.

Physical tests of two samples of the Whirlpool sandstone member (White Medina) of the Albion sandstone shot from wells in Erie County

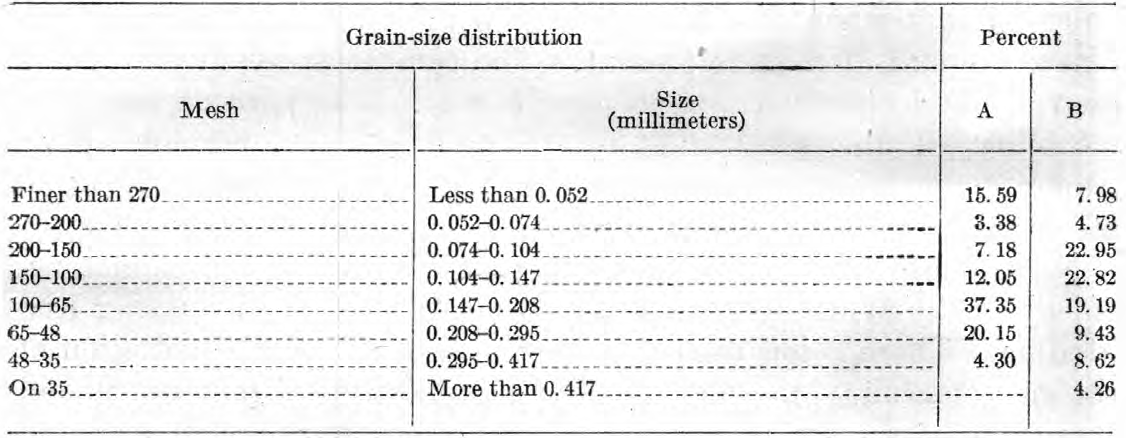

This mode of occurrence of the Medina gas makes the search for new fields in western New York more hazardous than in most naturalgas regions. As structure has not formed traps for the gas there is no surface guide to favorable sites for testing, and new fields are found by haphazard drilling. It would be helpful, however, when wells are sunk, to study the lithology of the gas-bearing zone by an examination of the drill cuttings and core samples of the sand, and to have electrical logs ${ }^{11}$ made of the wells to obtain measurements of permeability and porosity. Such tests may indicate the directions of greatest porosity, in which the sand is more likely to contain gas.

11 Gillingham, W. J., Electrical logging in the Appalachian fields: Pennsylvania State College Bull Mineral Industries Experiment Station No. 21, pp. 30-52, 1937. 
WEIL RECORDS

Records of selected wells drilled to the Onondaga limestone or deeper prior to 19361

[Locations shown on plate 5]

Allegany County

\begin{tabular}{|c|c|c|c|c|c|c|c|c|c|}
\hline \multirow{2}{*}{$\begin{array}{l}\text { No. on } \\
\text { pl. } 5\end{array}$} & \multirow{2}{*}{ Town } & \multirow{2}{*}{ Farm } & \multirow{2}{*}{$\begin{array}{l}\text { Approxi- } \\
\text { mate alti- } \\
\text { tude above } \\
\text { sea level } \\
\text { (feet) }\end{array}$} & \multicolumn{4}{|c|}{ Depth (feet) to top of- } & \multirow[b]{2}{*}{ Total deptb } & \multirow[b]{2}{*}{ Status } \\
\hline & & & & $\begin{array}{l}\text { Tully lime- } \\
\text { stone }\end{array}$ & $\begin{array}{l}\text { Onondaga } \\
\text { limestone }\end{array}$ & $\begin{array}{l}\text { Oriskany } \\
\text { sandstone }\end{array}$ & $\begin{array}{l}\text { Medina } \\
\text { group }\end{array}$ & & \\
\hline 1 & Hume. & Connor.. & 1,525 & & 2,456 & & 3,736 & 5,084 & Dry. \\
\hline $1 \mathrm{~A}$ & do & Buell ... & 1,447 & & 2,380 & & & 3,326 & Do. \\
\hline 2 & Caneadea & Thayer.... & 1,200 & & 2,245 & & & 2,447 & Do. \\
\hline 3 & Belfast. & Ford ..... & 1.725 & 2,808 & 3,287 & 3,378 & & 3,450 & Do. \\
\hline 4 & Angelica. & Clark... & 1,350 & 2,740 & 3,250 & 3. 368 & & 4,260 & Salt water. \\
\hline 5 & Allen.... & Sheldon & 1,630 & 2,340 & 2,856 & 2,964 & & 3,027 & Show of gas. \\
\hline 6 & ..... do . & Slaight .. & 1,654 & & 2,905 & 2,999 & & 3,050 & Dry. \\
\hline 7 & do & Vincent. & 1. 627 & 2,316 & 2,830 & 2,929 & & 2,959 & Gas. \\
\hline 8 & do. & Woodruff. & 1,644 & 2,358 & 2,864 & 2,962 & & 2,974 & Show of gas. \\
\hline 9 & do... & Smith & 1,595 & 2,279 & 2,780 & 2,873 & & 2,892 & Do. \\
\hline 10 & do & Bank of Angelica & 1.638 & 2,325 & 2,859 & 2,947 & & 2.948 & Do. \\
\hline 11 & do & Vincent & 1,655 & 2,349 & 2,855 & 2,956 & & 2,976 & Do. \\
\hline 12 & Wirt ... & Chadwick & 1,860 & 3,852 & 4,347 & 4,433 & & 4,850 & Dry. \\
\hline 13 & ... do & Dick..... & 2,140 & 4,114 & 4,620 & 4,688 & & 4,750 & Do. \\
\hline 14 & .... do . & Gilbert. & 2,071 & 3,990 & 4,538 & 4,630 & 6,024 & 6,250 & Gas. \\
\hline 15 & do & Reed & 2,130 & 4,063 & 4,650 & & & 4,675 & Dry. \\
\hline 16 & do . & Newton & 1,917 & $3,791(?)$ & 4,300 & 4,380 & 5,900 & 6,500 & Do. \\
\hline 17 & do. & Ballard.. & 2,101 & 4,005 & 4,514 & 4,559 & & 4,615 & Do. \\
\hline 19 & Burns & Bandoluh & 1,260 & & $2,650(?)$ & & & 3,200 & Do. \\
\hline 20 & Alfred & Randolph & 2,250 & 3,707 & 4,320 & 4,364 & & 4,381 & Salt water. \\
\hline 21 & Willing. & Ryan ..... & 2,074 & $4,211(?)$ & 4,803 & 4,835 & & 4,842 & Gas and salt water. \\
\hline 22 & Independence. & Clark. & 2,288 & 4,302 & 4,991 & 5,042 & & 5,050 & Salt water. \\
\hline 23 & Scio .... & Black. & 1. 778 & 3,470 & 4,025 & 4,097 & & 4,103 & Do. \\
\hline 24 & Bellast. & Murray & 1,634 & 2,641 . & 3,119 & 3,206 & & 3,210 & Gas. \\
\hline 25 & do... & Barringer. & 1,556 & 2,592 & 3,070 & 3,165 & & 3,165 & Water. \\
\hline 26 & Allen....... & Steadman & 1,685 & 2,325 & 2,814 & [Absent.] & & & Dry. \\
\hline 27 & Centerville. & Williams... & 1,915 & & 3,006 & .... & 4,251 & 4,388 & No white Medina. Dry. \\
\hline 28 & Willing .... & Costelo ... & 2,006 & 4,114 & 4,704 & 4,742 & & 4,744 & Gas. \\
\hline 29 & do... & Van Campen & 2,091 & $\begin{array}{l}7,117 \\
4,150\end{array}$ & 4,720 & 4,754 & & & Do. \\
\hline 30 & Alma. & Colligan..... & 1,954 & 3, 991 & 4,582 & 4,609 & & & Do. \\
\hline 31 & .... do .... & Dean..... & 1,970 & 4,000 & 4,580 & 4,627 & & 4,631 & Do. \\
\hline 32 & do $\ldots$ & Moran .. & 1,706 & 3,842 & & 4,428 & & & Do. \\
\hline 33 & Willing. & Loring.. & 1,855 & 4,041 & 4,627 & 4,668 & & & Salt water. \\
\hline
\end{tabular}

1 For records of wells in Wayne-Dundee, State-Line, and Greenwood gas fields see U. S. Geol. Survey Bull. 899-A. 
Broome County

\begin{tabular}{|c|c|c|c|c|c|c|c|c|c|}
\hline \multirow{2}{*}{$\begin{array}{l}\text { No.on } \\
\text { pl. } 5\end{array}$} & \multirow[b]{2}{*}{ Town } & \multirow{2}{*}{ Farm } & \multirow{2}{*}{$\begin{array}{l}\text { Approxi- } \\
\text { mate alti- } \\
\text { tude above } \\
\text { sea level } \\
\text { (feet) }\end{array}$} & \multicolumn{4}{|c|}{ Depth (feet) to top of- } & \multirow{2}{*}{ Total depth } & \multirow{2}{*}{ Status } \\
\hline & & & & $\begin{array}{c}\text { Tully lime- } \\
\text { stone }\end{array}$ & $\begin{array}{l}\text { Onondaga } \\
\text { limestone }\end{array}$ & $\begin{array}{c}\text { Oriskany } \\
\text { sandstone }\end{array}$ & $\begin{array}{l}\text { Medina } \\
\text { group }\end{array}$ & & \\
\hline 1 & Vestal... & Chase -. & 844 & . & 4,260 & 4,292 & & 4,412 & Dry. \\
\hline
\end{tabular}

Cattaraugus County

\begin{tabular}{|c|c|c|c|c|c|c|c|c|c|}
\hline 1 & Franklinville & Howard. & 1,625 & & 2,912 & & & 4,448 & Dry. \\
\hline 2 & Olean ........... & Quinlan. & 1,686 & 3,743 & 4,188 & 4,276 & & 4,297 & Do. \\
\hline 3 & Humphrey... & Hale............................ & 1,942 & -.. & 3,790 & - & 5,065 & & Do. \\
\hline 4 & Perrysburg.- & ................ & 960 & $\ldots$ & 1,535 & (-................ & 2,514 & (n................. & Do. \\
\hline 5 & ...... do ......... & (n........... & $\begin{array}{l}1,202 \\
977\end{array}$ & & $\begin{array}{l}1,774 \\
1,505\end{array}$ & $\cdots$ & $\begin{array}{l}2,752 \\
2,430\end{array}$ & $\cdots$ & $\begin{array}{l}\text { Do. } \\
\text { Do. }\end{array}$ \\
\hline $\begin{array}{l}6 \\
7\end{array}$ & .....do do & (n............... & 1,560 & $\cdots$ & 2,158 & $\ldots$ & 3,128 & $\cdots$ & Gas. \\
\hline 8 & 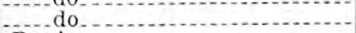 & & 1,227 & & 1,842 & & 2,777 & & Do. \\
\hline 9 & Persia & Palmer & 1,407 & $\cdots$ & $\begin{array}{l}2,119 \\
3,390\end{array}$ & $\cdots$ & $\begin{array}{l}3,232 \\
4,595\end{array}$ & 4,684 & Dry. \\
\hline $\begin{array}{l}10 \\
11\end{array}$ & $\begin{array}{l}\text { Randolph... } \\
\text { Perrysburg.. }\end{array}$ & Hotchkiss..................................... & $\begin{array}{l}1,704 \\
864\end{array}$ & $\cdots \cdot 1$ & $\begin{array}{l}0,390 \\
1,209\end{array}$ & & & $\begin{array}{l}4,004 \\
2,148\end{array}$ & Dry. \\
\hline 12 & Leon & Greeley. & 1,355 & & 2,330 & & 3,454 & 3,562 & Gas. \\
\hline 13 & Perrysburg.- & Hulbacken.- & 1,100 & -. & 1,645 & & 2,589 & $\cdots$ & Do. \\
\hline 14 & . do _ _ & Weils...... & 1,340 & & 1,920 & 457 & 2,884 & & Dry. \\
\hline 15 & Allegany ................................. & $\begin{array}{l}\text { Scott } \\
\text { Kewly }\end{array}$ & 1,877 & $3,830(?)$ & $\begin{array}{l}4,260 \\
1820\end{array}$ & 4,357 & $2.912 \quad-\quad 2$ & $\begin{array}{l}4,370 \\
3011\end{array}$ & Gas. \\
\hline $\begin{array}{l}10 \\
17\end{array}$ & Persia $\quad$ do & $\begin{array}{l}\text { Kewiy } \\
\text { Fog }\end{array}$ & $\begin{array}{l}1,150 \\
1,382\end{array}$ & ..... & $\begin{array}{l}1,020 \\
2,123\end{array}$ & $\ldots$ & 3,231 & 3,432 & Do. \\
\hline 18 & New Albion & Riche.- & 1,805 & & 2,710 & & 3.842 & 3,967 & Dry. \\
\hline 19 & Perrysburg........... & Retzel.............. & 1,135 & -................ & 1,710 & & 2,669 & $\begin{array}{l}2,884 \\
3,858\end{array}$ & Gas. \\
\hline 23 & Leon............ & Garvey ......... & 1,641 & $-1, \ldots+2$. & 2,584 & $\cdots$ & $\begin{array}{l}3,688 \\
2,194\end{array}$ & $\begin{array}{l}3,858 \\
3,075\end{array}$ & Dry. \\
\hline 24 & Dayton .............. & Jolls & $\begin{array}{l}1,361 \\
1,240\end{array}$ & $\cdots$ & $\begin{array}{l}1,958 \\
1,760\end{array}$ & $\cdots$ & $\begin{array}{l}2,194 \\
2,720\end{array}$ & $\begin{array}{l}3,075 \\
2,842\end{array}$ & Gas. Do. \\
\hline $\begin{array}{l}25 \\
26\end{array}$ & $\begin{array}{l}\text { Perrysburg } \\
\text { Farmersville }\end{array}$ & Arnold & $\begin{array}{l}1,240 \\
1,998\end{array}$ & (n) & $\begin{array}{l}1,100 \\
3,120\end{array}$ & (n............ & 4,321 & 4,444 & Dry. No White Medina. \\
\hline 28 & Yorkshire.............................. & 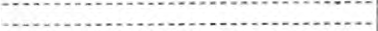 & 1,520 & & 2,397 & & 3,541 & 3,673 & Do. \\
\hline 29 & Otto & (n)....... & 1,199 & .... & 1,930 & ... & 3,050 & 3,167 & Gas. \\
\hline 30 & _.... do . . . & (n) & 1,389 & -................ & 2,135 & $\cdots$ & 3,237 & 3,342 & Do. \\
\hline 31 & 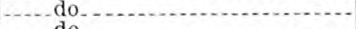 & nencencen & 1,399 & $\cdots$ & 2,150 & & & 3,377 & Dry. \\
\hline 32 & Persia & no & $\begin{array}{l}1,126 \\
1,372\end{array}$ & $\cdots$ & $\begin{array}{l}1,982 \\
2,116\end{array}$ & & $\begin{array}{l}3,058 \\
3,220\end{array}$ & 3,413 & $\begin{array}{l}\text { Gas. } \\
\text { Dry. }\end{array}$ \\
\hline $\begin{array}{l}33 \\
34\end{array}$ & Persia & о. & 1,324 & $\cdots$ & 2,126 & & 3,225 & 3,350 & Gas. \\
\hline & & & & & & & & & \\
\hline
\end{tabular}

Cayuga County

\begin{tabular}{|c|c|c|c|c|c|c|c|c|c|}
\hline 1 & Ledyard. & Mahaney & 824 & 17 & 1,010 & 1,065 & 3,093 & 6,166 & Dry. \\
\hline \multicolumn{10}{|c|}{ Chautauqua County } \\
\hline \multirow{41}{*}{$\begin{array}{r}1 \\
1 \mathrm{a} \\
2 \\
3 \\
4 \\
5 \\
6 \\
7 \\
8 \\
9 \\
10 \\
11 \\
12 \\
13 \\
14 \\
15 \\
16 \\
17 \\
18 \\
20 \\
22 \\
23 \\
24 \\
25 \\
26 \\
27 \\
28 \\
29 \\
30 \\
31 \\
32 \\
33 \\
34 \\
35 \\
36 \\
37 \\
38 \\
39 \\
40 \\
41 \\
42 \\
43 \\
44\end{array}$} & Jamestown & & 1,325 & & 2,775 & & & 3,263 & \\
\hline & Kiantone... & Weiss & 1,244 & & 2,999 & & 4,194 & 4,700 & Do. \\
\hline & Villenova. & Phillips.. & 1,310 & & 1,985 & & 3,077 & 3,219 & Do. \\
\hline & …do do & Wood... & 1,665 & $\ldots$ & 2,240 & & 3,325 & 3,467 & Do. \\
\hline & do & Parell & 1,720 & $\cdots$ & 2,315 & & 3,270 & 3,417 & Gas. \\
\hline & Hanover. . & Parsell... & $\begin{array}{r}1,420 \\
880\end{array}$ & & $\begin{array}{l}1,970 \\
1,176\end{array}$ & $\cdots$ & $\begin{array}{l}2,974 \\
2,165\end{array}$ & $\begin{array}{l}3,093 \\
2,289\end{array}$ & Do. \\
\hline & do................... & - & 1,120 & & 1,502 & & 2,496 & & Dry. \\
\hline & Sheridan & (1)................. & 1,080 & $\ldots . .$. & 1,402 & $\cdots$ & 2,373 & 2,552 & Gas. \\
\hline & …. do . . . & $\begin{array}{l}\text { Livermore } \\
\text { Berns }\end{array}$ & $\begin{array}{l}880 \\
850\end{array}$ & $\ldots . .$. & 1,160 & & 2,129 & & Do. \\
\hline & .... do do & $\begin{array}{l}\text { Berns ........... } \\
\text { Ransom }\end{array}$ & $\begin{array}{r}850 \\
1,080\end{array}$ & $\ldots$ & $\begin{array}{l}1,121 \\
1,400\end{array}$ & & 2,092 & $\begin{array}{l}2,234 \\
2,396\end{array}$ & $\begin{array}{l}\text { Do. } \\
\text { Do. }\end{array}$ \\
\hline & Arkwright & Thiess.......... & $\begin{array}{l}1,000 \\
1,620\end{array}$ & $\cdots$ & $\begin{array}{l}1,400 \\
2,084\end{array}$ & & 3,037 & 3,182 & $\begin{array}{l}\text { Do. } \\
\text { Do. }\end{array}$ \\
\hline & ..... do & Beebe... & 1,130 & & 1,656 & & 2,623 & 2,783 & Do. \\
\hline & Sheridan .... & - & 720 & $\ldots$ & 955 & & 1,895 & & Do. \\
\hline & .... do ...... & & 780 & & 1,090 & & & & Do. \\
\hline & ..... do...... & Woods ..... & 1,922 & & 1,065 & & 2,038 & & Do. \\
\hline & $\ldots$ do $\ldots . . . .$. & Gens and Wright .................. & 1,925 & & 1,210 & & 2,181 & & Do. \\
\hline & Pomfret.... & & 780 & & 1,150 & & & & \\
\hline & Arkwright_ & R. and E. The & 1,925 & & 1,500 & & 2,469 & & Do. \\
\hline & Portland... & Wenborne.... & 640 & $\ldots$ & 1.010 & & 1,978 & 2,128 & Do. \\
\hline & North Harmony. & Randall .... & 1,530 & & 2,610 & $\ldots$ & 3,717 & 3,895 & Dry. \\
\hline & Hanover.... & Lake Shore.. & 580 & & 710 & & 1,672 & 1,835 & Do. \\
\hline & Sheridan. & Baily ............ & 600 & $\ldots$ & 700 & $\ldots$ & 1,728 & 1,859 & Gas. \\
\hline & . do ........... & St. Columbans & 590 & $\ldots$ & 680 & $\ldots$ & 1,680 & 1,837 & Do. \\
\hline & Hanover.. & Bently .... & 650 & & 820 & & 1,773 & 1,891 & Do. \\
\hline & ..... do ..... & Smith .... & 760 & & 1,000 & $\ldots$ & 1,937 & 2,080 & \\
\hline & .... do ..... & Ubel & 828 & $\ldots$ & 1,105 & & 2,061 & 2,286 & \\
\hline & ..... do ...... & James.... & 737 & & 990 & & 1,924 & 2,147 & \\
\hline & .... do..... & Jacobs.... & 800 & .... & 1,070 & & 1,996 & 2,145 & \\
\hline & .... do & Taylor $\ldots$ & 625 & $\cdots$ & 820 & $\ldots$ & 1,764 & 1,897 & \\
\hline & ...... do ........ & Codwell .... & 590 & & 775 & $\ldots$. & 1,707 & 1,787 & \\
\hline & .... do .......... & Bradley.... & 600 & & 785 & & 1,728 & 1,798 & \\
\hline & do do , n & Smith & 770 & $\ldots$ & 1,005 & & 1,951 & 2,111 & \\
\hline & ..... do & Frye $\ldots . . .$. & 740 & $\ldots$ & 950 & $\ldots$ & 1,910 & 2,050 & \\
\hline & .... do & De Salvo ... & 805 & & 1,085 & & 2,043 & 2,178 & \\
\hline & do ...................... & Brown & 695 & $\ldots$ & 825 & $\ldots$ & 1,808 & 1,963 & \\
\hline & do & Pogano & 677 & $\ldots$ & 825 & ...... & 1,775 & 1,850 & \\
\hline & do & Mirth ........ & 706 & & $832^{\circ}$ & & 1,809 & 1,964 & \\
\hline & Pomfret. & Sanderson.... & 1,232 & & 1,798 & & 2,805 & 2,982 & \\
\hline & Stockton & Warren ....... & 1,320 & .... & 1,950 & & 2,944 & 3,116 & \\
\hline & Pomfret .... & & 610 & & 895 & & 1,870 & 2,026 & \\
\hline & Sheridan.... & Merritt_..... & 785 & 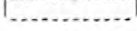 & 1,090 & 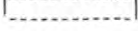 & 2,055 & 2,241 & \\
\hline
\end{tabular}


Chautauqua County-Continued

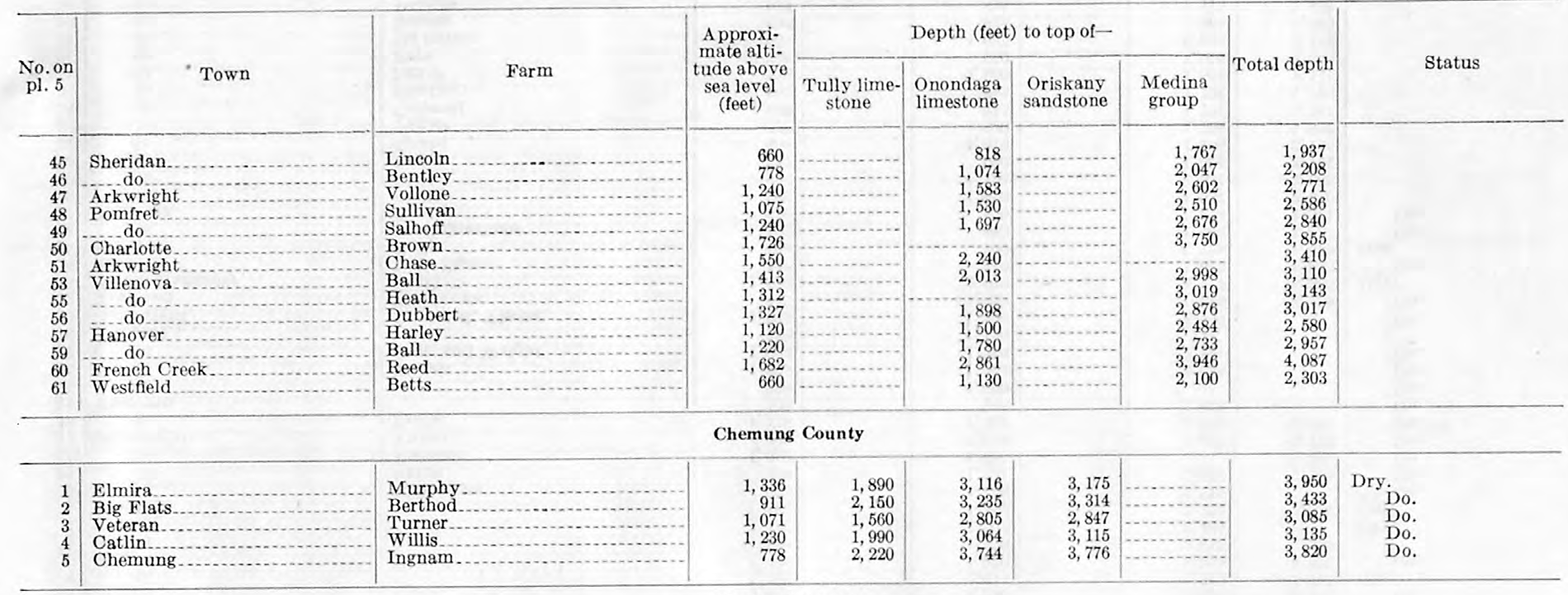

Cortland County

\begin{tabular}{|c|c|c|c|c|c|c|c|c|}
\hline \multicolumn{9}{|c|}{ Cortland County } \\
\hline 1 & Harford. . & Woodward & 1,174 & 1,044 & 2,475 & 2,504 & 2,776 & Dry. \\
\hline \multicolumn{9}{|c|}{ Erie County } \\
\hline
\end{tabular}

\section{Erie County}

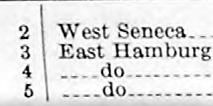

\section{\begin{tabular}{l|l}
$\ddot{7}$ & Hamburg \\
8 & East Hamburg \\
\hline
\end{tabular}}

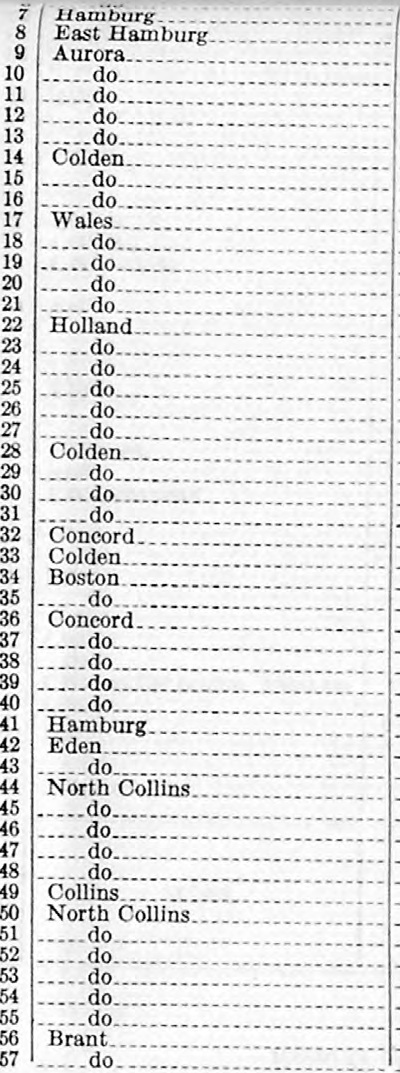

720
730
780
780

\begin{tabular}{|c|c|}
\hline $\begin{array}{l}660 \\
940\end{array}$ & \\
\hline 880 & \\
\hline $\begin{array}{r}970 \\
310\end{array}$ & \\
\hline $\begin{array}{l}1,310 \\
1,195\end{array}$ & \\
\hline 1,240 & \\
\hline 1,382 & \\
\hline $\begin{array}{l}1,543 \\
1,440\end{array}$ & \\
\hline $\begin{array}{l}1,70 \\
935\end{array}$ & \\
\hline 1,425 & \\
\hline 1,131 & \\
\hline $\begin{array}{l}1,405 \\
1,133\end{array}$ & \\
\hline 1,261 & \\
\hline 1,486 & \\
\hline $\begin{array}{r}982 \\
1,103\end{array}$ & \\
\hline $\begin{array}{l}1,252 \\
1\end{array}$ & \\
\hline 1,112 & \\
\hline 1,651 & \\
\hline $\begin{array}{l}1,726 \\
1,330\end{array}$ & \\
\hline $\begin{array}{l}1,607 \\
\end{array}$ & \\
\hline 1,244 & \\
\hline 1,141 & \\
\hline $\begin{array}{l}1,610 \\
1,020\end{array}$ & \\
\hline 1,071 & \\
\hline 1,199 & \\
\hline $\begin{array}{l}1,340 \\
1,459\end{array}$ & \\
\hline 1,407 & \\
\hline 820 & \\
\hline $\begin{array}{l}977 \\
836\end{array}$ & \\
\hline 974 & \\
\hline 1,065 & $\ldots$ \\
\hline 1,418 & \\
\hline $\begin{array}{l}1,267 \\
1,431\end{array}$ & $\ldots$ \\
\hline 1,440 & 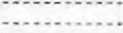 \\
\hline 1,542 & \\
\hline $\begin{array}{l}1,213 \\
1,178\end{array}$ & \\
\hline 1,313 & $\cdots$ \\
\hline 1,262 & \\
\hline $\begin{array}{l}822 \\
866\end{array}$ & \\
\hline 91 . & \\
\hline
\end{tabular}

318
350
507
490

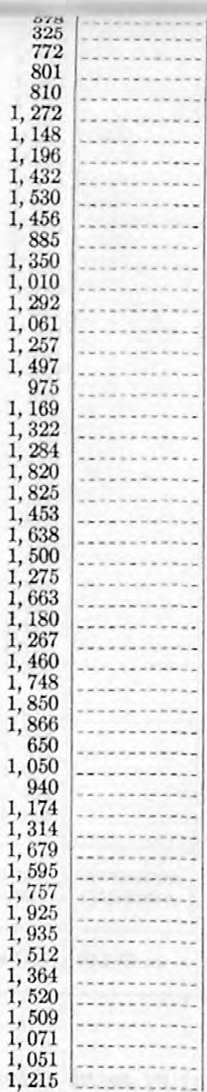

\begin{tabular}{l|l|r}
1,223 & $\ldots \ldots \ldots \ldots \ldots$ & Gas. \\
1,270 & $\ldots \ldots \ldots \ldots \ldots$ & Do. \\
1,423 & $\ldots \ldots \ldots \ldots \ldots$. & Do. \\
1,418 & $\ldots \ldots \ldots \ldots \ldots$ & Do.
\end{tabular}

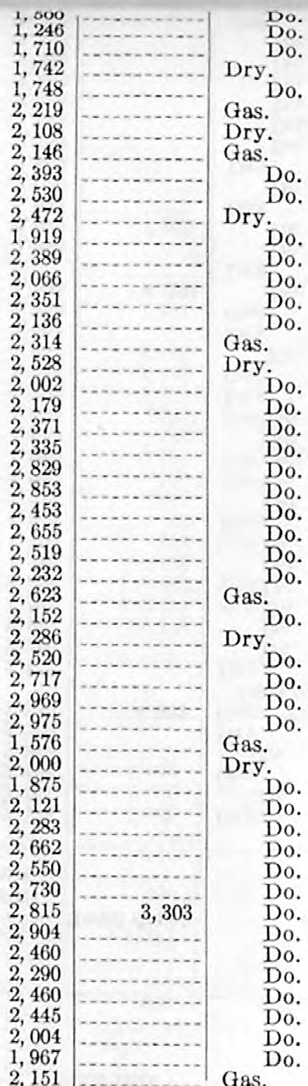

\section{.}


Erie County-Continued

\begin{tabular}{|c|c|c|c|c|c|c|c|c|c|}
\hline \multirow[b]{2}{*}{$\begin{array}{l}\text { No. on } \\
\text { pl. } 5\end{array}$} & \multirow[b]{2}{*}{ Town } & \multirow[b]{2}{*}{ Farm } & \multirow{2}{*}{$\begin{array}{c}\text { Approxi- } \\
\text { mate alti- } \\
\text { tude above } \\
\text { sea level } \\
\text { (feec) }\end{array}$} & \multicolumn{4}{|c|}{ Depth (feet) to top of- } & \multirow[b]{2}{*}{ Total depth } & \multirow[b]{2}{*}{ Status } \\
\hline & & & & $\begin{array}{c}\text { Tully lime- } \\
\text { stone }\end{array}$ & $\begin{array}{l}\text { Onondaga } \\
\text { limestone }\end{array}$ & $\begin{array}{l}\text { Oriskany } \\
\text { sandstone }\end{array}$ & $\underset{\text { group }}{\text { Medina }}$ & & \\
\hline $\begin{array}{l}58 \\
59\end{array}$ & $\begin{array}{l}\text { North Collins. } \\
\text { do }\end{array}$ & & 819 & & 1,180 & & 2,129 & & Dry. \\
\hline $\begin{array}{l}59 \\
60 \\
61\end{array}$ & _... do & & $\begin{array}{l}1,115 \\
1,147\end{array}$ & $\ldots . .$. & $\begin{array}{l}1,420 \\
1,494\end{array}$ & & $\begin{array}{l}2,364 \\
2,449\end{array}$ & & $\begin{array}{l}\text { Do. } \\
\text { Gas. }\end{array}$ \\
\hline $\begin{array}{l}61 \\
62\end{array}$ & Collins & (n....... & $\begin{array}{l}1,147 \\
935 \\
1.307\end{array}$ & & 1,280 & & 2,246 & & Gas. \\
\hline $\begin{array}{l}62 \\
63\end{array}$ & Cattaraugus Indian Reserva- & -....... & $\begin{array}{r}1,307 \\
650\end{array}$ & & $\begin{array}{r}1,777 \\
940\end{array}$ & & $\begin{array}{l}2,729 \\
1,850\end{array}$ & 4,602 & $\begin{array}{l}\text { Dry. } \\
\text { Gas. Top of "granite," }\end{array}$ \\
\hline $\begin{array}{l}64 \\
65\end{array}$ & $\begin{array}{l}\text { tion. } \\
\text { Collins }\end{array}$ & & 827 & & 1,220 & & 2,155 & & $\begin{array}{l}\text { Gas. } 600 \text { feet. } \\
\text { Dry. }\end{array}$ \\
\hline $\begin{array}{l}65 \\
66\end{array}$ & do & 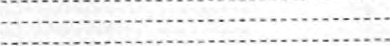 & $\begin{array}{r}893 \\
1,107\end{array}$ & & $\begin{array}{l}1,309 \\
1,590\end{array}$ & & 2,260 & & $\begin{array}{l}\text { Dry. Do. } \\
\text { Do. }\end{array}$ \\
\hline $\begin{array}{l}67 \\
68\end{array}$ & Elma & ........... & $\begin{array}{l}1,107 \\
920\end{array}$ & $\cdots \ldots$. & $\begin{array}{r}1,590 \\
575\end{array}$ & & $\begin{array}{l}2,599 \\
1,517\end{array}$ & $\cdots$ & $\begin{array}{l}\text { Do. } \\
\text { Do. }\end{array}$ \\
\hline $\begin{array}{l}68 \\
69\end{array}$ & do do & ............ & $\begin{array}{l}860 \\
790\end{array}$ & ........ & 475 & & 1,397 & $\cdots$. & Do. \\
\hline $\begin{array}{l}69 \\
70 \\
71\end{array}$ & do do & (n)....... & $\begin{array}{l}790 \\
823\end{array}$ & 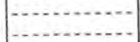 & $\begin{array}{l}338 \\
495\end{array}$ & & $\begin{array}{l}1,280 \\
1,400\end{array}$ & ...... & $\begin{array}{l}\text { Do. } \\
\text { Do. }\end{array}$ \\
\hline $\begin{array}{l}71 \\
72\end{array}$ & $\begin{array}{l}\text { East Hamburg } \\
\text { Elma }\end{array}$ & n.............. & $\begin{array}{l}875 \\
772\end{array}$ & ....... & 600 & & 1,515 & & \\
\hline $\begin{array}{c}72 \\
73 \\
74\end{array}$ & \begin{tabular}{|l|} 
Elma \\
Lancaster........
\end{tabular} & & $\begin{array}{l}772 \\
750\end{array}$ & $\cdots . .$. & $\begin{aligned} 280 \\
95\end{aligned}$ & & $\begin{array}{l}1,211 \\
1,032\end{array}$ & $\cdots$ & $\begin{array}{l}\text { Do. } \\
\text { Do. }\end{array}$ \\
\hline $\begin{array}{l}74 \\
75 \\
75\end{array}$ & … do & ............. & 740 & & $\begin{array}{r}130 \\
90\end{array}$ & & $\begin{array}{l}1,070 \\
1,00\end{array}$ & $\cdots$ & $\begin{array}{l}\text { Do. } \\
\text { Do. }\end{array}$ \\
\hline $\begin{array}{l}75 \\
76\end{array}$ & Evans & - & $\begin{array}{l}692 \\
590\end{array}$ & $\cdots$ & $\begin{array}{r}90 \\
595\end{array}$ & & $\begin{array}{l}1,025 \\
1,525\end{array}$ & 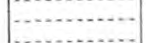 & $\begin{array}{l}\text { Do. } \\
\text { Do. }\end{array}$ \\
\hline $\begin{array}{l}76 \\
77\end{array}$ & Evans ..... & - & 658 & $\cdots$ & 575 & & $\begin{array}{l}1,520 \\
1,499\end{array}$ & $\ldots$ & $\begin{array}{l}\text { Do. } \\
\text { Dry. }\end{array}$ \\
\hline $\begin{array}{l}78 \\
79\end{array}$ & ...do do.... & (n)................ & $\begin{array}{l}706 \\
607\end{array}$ & $\cdots$ & $\begin{array}{l}570 \\
580\end{array}$ & & 1,485 & & Gas. \\
\hline $\begin{array}{l}79 \\
80\end{array}$ & Brant & (-)......... & $\begin{array}{l}607 \\
666 \\
-70\end{array}$ & - & $\begin{array}{l}580 \\
760\end{array}$ & & $\begin{array}{l}1,491 \\
1,687\end{array}$ & & $\begin{array}{l}\text { Do. } \\
\text { Dry. }\end{array}$ \\
\hline $\begin{array}{l}80 \\
81 \\
82\end{array}$ & $\begin{array}{l}\text { Brant } \\
\text { do }\end{array}$ & 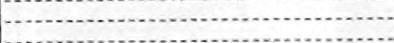 & 766 & ......... & 943 & & 1,883 & & $\begin{array}{l}\text { Dry. } \\
\text { Gas. }\end{array}$ \\
\hline $\begin{array}{l}82 \\
83 \\
83\end{array}$ & $\begin{array}{l}\text { Cattaraugus } \\
\text { Concord }\end{array}$ & …... & $\begin{array}{r}740 \\
1.300\end{array}$ & $\ldots$ & $\begin{array}{r}850 \\
1,800\end{array}$ & & 1,805 & 4,560 & \\
\hline $\begin{array}{l}83 \\
84\end{array}$ & $\begin{array}{l}\text { Concord } \\
\text { Collins... }\end{array}$ & 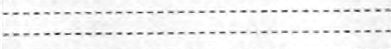 & $\begin{array}{r}1,300 \\
816\end{array}$ & & $\begin{array}{l}1,327 \\
1,580\end{array}$ & & 2,286 & & Dry. \\
\hline 85 & . do & - & $\begin{array}{l}1,040 \\
1,295\end{array}$ & $\cdots$ & $\begin{array}{l}1,580 \\
1,910\end{array}$ & & 2,620 & & Do. \\
\hline $\begin{array}{l}86 \\
87\end{array}$ & do & (n........... & $\begin{array}{l}1,295 \\
1,054\end{array}$ & $-\cdots .$. & $\begin{array}{l}1,910 \\
1,575\end{array}$ & & $\begin{array}{l}1,045 \\
2,620\end{array}$ & & $\begin{array}{l}\text { Gas. } \\
\text { Do. }\end{array}$ \\
\hline $\begin{array}{l}87 \\
88\end{array}$ & do...do do & - & 1,330 & -...... & 1,854 & & $\begin{array}{l}2,849 \\
232\end{array}$ & & Dry \\
\hline $\begin{array}{l}89 \\
90\end{array}$ & Wales & -............ & $\begin{array}{r}1,045 \\
991\end{array}$ & $\ldots$ & $\begin{array}{r}1,609 \\
897\end{array}$ & & $\begin{array}{l}2,732 \\
1,941\end{array}$ & & $\begin{array}{l}\text { Do. } \\
\text { Do. }\end{array}$ \\
\hline $\begin{array}{l}90 \\
91\end{array}$ & Wales & 1. & $\begin{array}{r}991 \\
1,082\end{array}$ & $\cdots$ & 1,047 & & 2,124 & & $\begin{array}{l}\text { Do. } \\
\text { Do. }\end{array}$ \\
\hline $\begin{array}{l}92 \\
93\end{array}$ & do & & 1,447 & $\ldots$ & $\begin{array}{l}1,387 \\
1,515\end{array}$ & & 2,439 & & \\
\hline $\begin{array}{l}93 \\
94\end{array}$ & Holland. & (n) & $\begin{array}{l}1,361 \\
1,082\end{array}$ & $\cdots$ & $\begin{array}{l}1,515 \\
1,678\end{array}$ & & $\begin{array}{l}2,569 \\
2,648\end{array}$ & & $\begin{array}{l}\text { Do. } \\
\text { Do. }\end{array}$ \\
\hline $\begin{array}{l}95 \\
96\end{array}$ & Sardinia- & - & $\begin{array}{l}1,450 \\
1,082\end{array}$ & & $\begin{array}{r}1,990 \\
810\end{array}$ & & $\begin{array}{l}3,107 \\
1,789\end{array}$ & 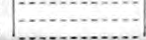 & $\begin{array}{l}\text { Gas. } \\
\text { Dry. }\end{array}$ \\
\hline & Marilla & n. & $\begin{array}{l}1,082 \\
1,100\end{array}$ & ................. & $\begin{array}{r}802 \\
802\end{array}$ & & $\begin{array}{l}1,789 \\
1,767\end{array}$ & & \\
\hline $\begin{array}{r}98 \\
99\end{array}$ & Eden & (............... & $\begin{array}{l}1,076 \\
750\end{array}$ & $\ldots$ & 777 & & $\begin{array}{l}1,767 \\
1,763\end{array}$ & $\cdots+. .$. & Gas. \\
\hline $\begin{array}{l}39 \\
100 \\
101\end{array}$ & 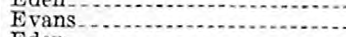 & (n................. & 715 & $\cdots$ & $\begin{array}{l}585 \\
585\end{array}$ & & 1,480 & - & \\
\hline $\begin{array}{l}101 \\
102\end{array}$ & Eden... & & 820 & ...... & 720 & $\ldots$ & 1,636 & $\cdots$ & \\
\hline 103 & Evans. & 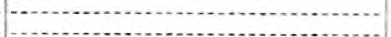 & 785 & $\cdots \cdots$ & $\begin{array}{r}821 \\
775\end{array}$ & & 1,742 & & \\
\hline $\begin{array}{l}105 \\
106\end{array}$ & do do & Cettoroume Indian Dech & 1,240 & & $\begin{array}{l}1,110 \\
1,363 \\
1,170\end{array}$ & & $\begin{array}{l}2,480 \\
2,312\end{array}$ & $\cdots . .$. & \\
\hline $\begin{array}{l}106 \\
107\end{array}$ & Collins & Cattaraugus Indian Reservation & $\begin{array}{l}789 \\
815\end{array}$ & .......... & $\begin{array}{l}1,172 \\
1,215\end{array}$ & $\cdots+.$. & 2,106 & & \\
\hline $\begin{array}{l}108 \\
109\end{array}$ & do & . do $\ldots$ do & 838 & & 1,160 & $\cdots+$. & $\begin{array}{l}2,162 \\
2,081\end{array}$ & 2,392 & \\
\hline $\begin{array}{l}109 \\
110\end{array}$ & Brant & Jackson... & 855 & & 1,190 & & 2,131 & & \\
\hline 111 & do ........................ & $\begin{array}{l}\text { Jackson.......... } \\
\text { Patterson...... }\end{array}$ & $\begin{array}{l}655 \\
620\end{array}$ & $\cdots . .$. & 740 & $\ldots$ & 1,670 & 1,801 & \\
\hline 112 & ..... do .. & Pierce & 585 & $\cdots+$. & 700 & 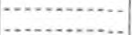 & & 1,851 & \\
\hline $\begin{array}{l}113 \\
114\end{array}$ & 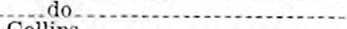 & White-_._. & 765 & $\cdots$ & 962 & & 1,876 & 2,019 & \\
\hline $\begin{array}{l}114 \\
115\end{array}$ & $\begin{array}{l}\text { Collins. } \\
\text { Brant. }\end{array}$ & $\begin{array}{l}\text { Seneca. } \\
\text { George.................... }\end{array}$ & 620 & ........... & $\begin{array}{l}890 \\
762\end{array}$ & & 1,810 & 1,929 & \\
\hline 116 & 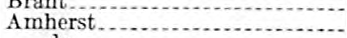 & Becker ..................... & 590 & & & & 1,702 & 1,824 & Gas \\
\hline $\begin{array}{l}117 \\
118\end{array}$ & do & & 590 & & & & 635 & 740 & Gas. Do. \\
\hline 119 & 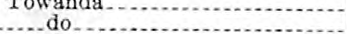 & & 585 & 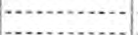 & 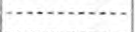 & $\cdots$ & 620 & 735 & Gas in Clinton. \\
\hline 120 & .....do & ............... & 580 & $\cdots$ & ...... & $\cdots$ & 583 & $\begin{array}{l}707 \\
677\end{array}$ & Gas. Do. \\
\hline 121 & ....do & (a). & $\begin{array}{cc}575 \\
575\end{array}$ & W. & 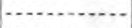 & & 548 & 662 & Do. \\
\hline $\begin{array}{l}122 \\
123\end{array}$ & .... do do. & . & 580 & & & & 540 & 664 & Gas in Clinton. \\
\hline 124 & Collins & Holcomb & 1,410 & $\cdots$ & 2,040 & & 3,076 & $\begin{array}{r}698 \\
3,193\end{array}$ & Dry. \\
\hline $\begin{array}{l}125 \\
126\end{array}$ & do & $\begin{array}{l}\text { Corbett } \\
\text { Cattaraugus Indian Reservation... }\end{array}$ & $\begin{array}{l}790 \\
835\end{array}$ & ............ & $\begin{array}{l}1,337 \\
1,345\end{array}$ & & $\begin{array}{l}2,299 \\
2,316\end{array}$ & $\begin{array}{l}2,515 \\
2,526\end{array}$ & Gas. \\
\hline & & & & & & & & 2,526 & \\
\hline
\end{tabular}

Genesee County

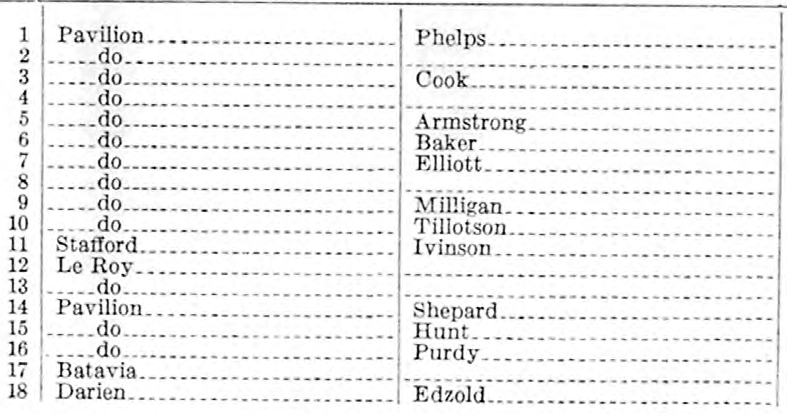

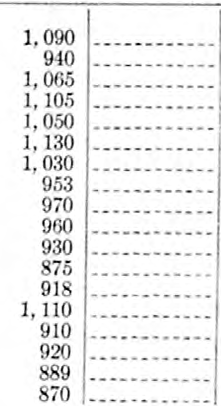

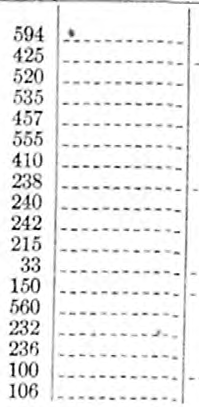

\begin{tabular}{|c|c|c|}
\hline 1,808 & & \\
\hline $\begin{array}{l}1,685 \\
1,701\end{array}$ & $\begin{array}{l}1,073 \\
1,816\end{array}$ & \\
\hline $\begin{array}{l}1,701 \\
1,641\end{array}$ & 1,825 & \\
\hline $\begin{array}{l}1,708 \\
1,554\end{array}$ & & \\
\hline & $878+$ & \\
\hline $\begin{array}{l}1,380 \\
1,356 \\
1\end{array}$ & & \\
\hline 1,334 & 1,514 & \\
\hline 1,772 & $\begin{array}{l}650 \pm \\
805 \pm\end{array}$ & \\
\hline $\begin{array}{l}1,344 \\
1,399\end{array}$ & & \\
\hline 075 & 2,000 & \\
\hline
\end{tabular}


Records of selected wells drilled to the Onondaga limestone or deeper prior to 1936 -Continued

Genesee County-Continued

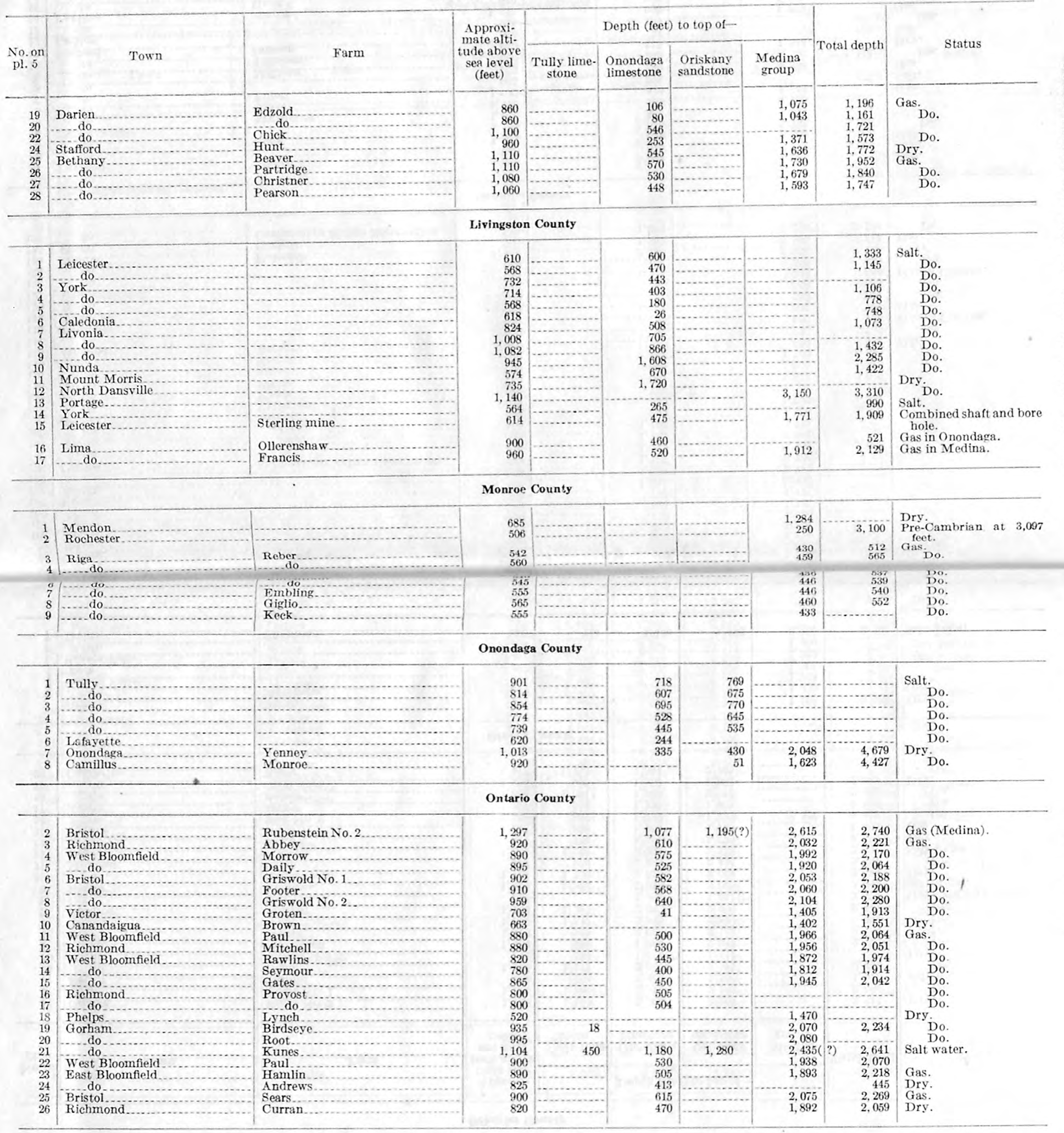


Schuyler County

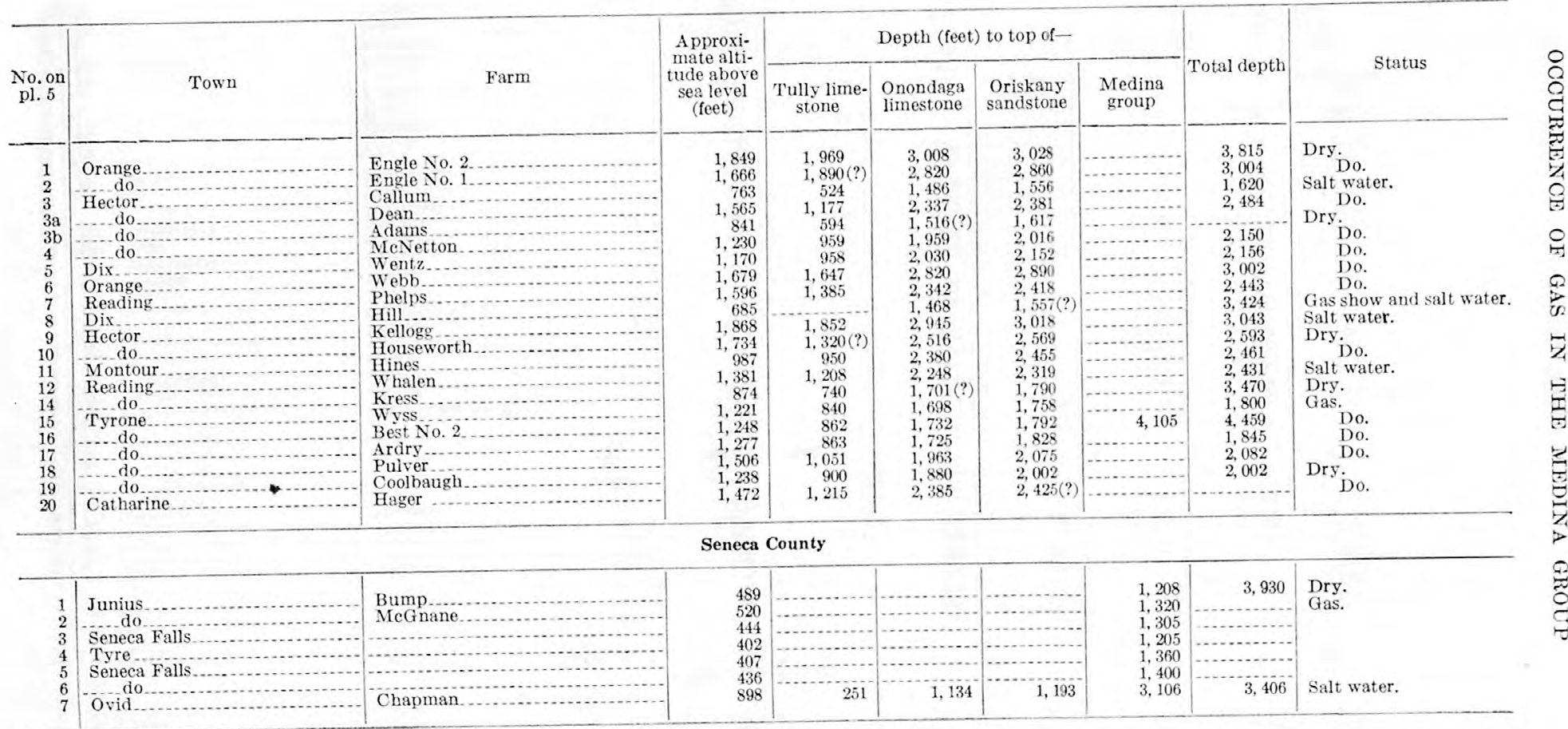

\begin{tabular}{|c|c|c|c|c|c|c|c|c|c|}
\hline 1 & Urbana. . & Abbot... & 982 & 1,473 & 2,257 & 2,343 & & 2,780 & Dry. \\
\hline 2 & & Wood....... & 1,394 & 1,740 & 2,470 & 2,554 & & 2,502 & Do. \\
\hline $\begin{array}{l}3 \\
4\end{array}$ & Prattsburg....... & Daltry ................. & 1,345 & $\begin{array}{l}1,364 \\
2,155\end{array}$ & 2,100 & $\begin{array}{l}2,145 \\
2,896\end{array}$ & & $\begin{array}{l}2,502 \\
2,952\end{array}$ & $\begin{array}{l}\text { Do. } \\
\text { Do. }\end{array}$ \\
\hline $4 \mathrm{a}$ & Bath & White & $\begin{array}{l}1,851 \\
1,082\end{array}$ & $\begin{array}{l}2,100 \\
1,910\end{array}$ & 2,679 & 2,710 & & 2,946 & $\begin{array}{l}\text { Do. } \\
\text { Dry (no sand). }\end{array}$ \\
\hline 5 & Campbell.. & Pooley ..... & 1,046 & 2,020 & 2,910 & 2,936 & & 2,947 & $\begin{array}{l}\text { Dry (no sand). } \\
\text { Salt water. }\end{array}$ \\
\hline 6 & Erwin ....... & Lilly.......... & 1,624 & 2,865 & 3,790 & 3,826 & & 3,838 & Do. \\
\hline 7 & Caton ..... & Monroe..... & 1,552 & 3,692 & $\begin{array}{l}4,706 \\
4,098\end{array}$ & 4,736 & & $\begin{array}{l}4,769 \\
4,135\end{array}$ & Dry. \\
\hline $\begin{array}{l}8 \\
9\end{array}$ & $\begin{array}{l}\text { Canisteo ................. } \\
\text { Jasper }\end{array}$ & $\begin{array}{l}\text { Porter } \\
\text { Broughton }\end{array}$ & $\begin{array}{l}1,889 \\
1,545\end{array}$ & $\begin{array}{l}3,415 \\
3,270(?)\end{array}$ & $\begin{array}{l}4,098 \\
3,938\end{array}$ & $\begin{array}{l}4,130 \\
3,993\end{array}$ & & $\begin{array}{l}4,135 \\
4,003\end{array}$ & $\begin{array}{l}\text { Salt water. } \\
\text { Do. }\end{array}$ \\
\hline 10 & Greenwood & Kellogg ............... & 1,619 & 3,453 & $\begin{array}{l}3,080 \\
4,083\end{array}$ & 4,143 & & 4,164 & Do. \\
\hline $\begin{array}{l}11 \\
12\end{array}$ & ...... do ........ & Stateland... & 2,222 & 4,021 & 4,676 & 4,702 & & & Gas. \\
\hline $\begin{array}{l}12 \\
12 \mathrm{a}\end{array}$ & ..... do do & $\begin{array}{l}\text { Webber } \\
\text { Coston No. } 1 . . . . . .\end{array}$ & $\begin{array}{l}1,791 \\
2,016\end{array}$ & $\begin{array}{l}3,554 \\
3,816\end{array}$ & $\begin{array}{l}4,203 \\
4,496\end{array}$ & $\begin{array}{l}4,256 \\
4,538\end{array}$ & & $\begin{array}{l}4,266 \\
4,547\end{array}$ & $\begin{array}{l}\text { Do. } \\
\text { Salt water. }\end{array}$ \\
\hline 13 & do & Wariner & $\begin{array}{l}2,016 \\
2,079\end{array}$ & $\begin{array}{l}3,810 \\
3,880\end{array}$ & $\begin{array}{l}4,490 \\
4,514\end{array}$ & $\begin{array}{l}4,530 \\
4,550\end{array}$ & & 4,558 & Gas. \\
\hline $13 \mathrm{a}$ & ..... do......... & Coston No. 2 & 2,299 & 4,057 & 4,715 & 4,737 & & 4,738 & Do. \\
\hline $\begin{array}{l}14 \\
14 \mathrm{a}\end{array}$ & ...... do do....... & MeCormick. & 2,234 & $\begin{array}{r}4,243 \\
4,043\end{array}$ & 4,911 & 4,941 & & 4,946 & $\begin{array}{l}\text { Salt water. } \\
\text { Gas. }\end{array}$ \\
\hline 15 & Urbana & $\begin{array}{l}\text { O'Harrigan ... } \\
\text { Wood ........ }\end{array}$ & 2,284 & $\begin{array}{l}4,043 \\
1,131\end{array}$ & $\begin{array}{l}4,698 \\
1,937\end{array}$ & $\begin{array}{l}4,728 \\
1,962\end{array}$ & & $\begin{array}{l}4,729 \\
2,059\end{array}$ & $\begin{array}{l}\text { Gas. } \\
\text { Dry. }\end{array}$ \\
\hline 16 & Bradford.... & White................ & 1,680 & 2,395 & 3,336 & 3,388 & & 3,405 & Salt water. \\
\hline 17 & Thurston & Talbot ....... & 1,195 & 1,944 & 2,962 & 2,890 & & 3,005 & Do. \\
\hline $\begin{array}{l}18 \\
19\end{array}$ & Dansville & $\begin{array}{l}\text { Eichorn } \\
\text { Magin.... }\end{array}$ & $\begin{array}{l}2,006 \\
2,071\end{array}$ & $\begin{array}{l}2,664 \\
2,713\end{array}$ & $\begin{array}{l}3,278 \\
3,317\end{array}$ & $\begin{array}{l}3,345 \\
3,409\end{array}$ & & 3,369 & $\begin{array}{l}\text { Do. } \\
\text { Dry. Shows of gas in }\end{array}$ \\
\hline 20 & Howard .... & Ford ......... & 1872 & $2065(?)$ & 3.475 & 3.505 & & 3640 & $\begin{array}{l}\text { Marcellus and Onon- } \\
\text { daga. }\end{array}$ \\
\hline 21 & Pulteney... & Kilbury. & 1210 & $2,800(1)$ & & 1.92 & & 3,040 & $\begin{array}{l}\text { Salt water and carbon } \\
\text { dioxide. }\end{array}$ \\
\hline 22 & Woodhull. & Fenner-Taft. & $\begin{array}{l}1,210 \\
1,500\end{array}$ & $\begin{array}{l}1,047 \\
3,198(?)\end{array}$ & $\begin{array}{l}1,824 \\
4.046(?)\end{array}$ & $\begin{array}{l}1,92 \\
4,106(?)\end{array}$ & .... & $\begin{array}{l}1,947 \\
4,106\end{array}$ & Salt water. \\
\hline 23 & Rathbone & Perkins.. & $\begin{array}{l}1,500 \\
1,664\end{array}$ & $\begin{array}{l}3,195(1) \\
3,300\end{array}$ & $\begin{array}{l}4,200(\cdot) \\
4,200\end{array}$ & 4,232 & ...... & 4,438 & $\begin{array}{l}\text { Dry. } \\
\text { Do. }\end{array}$ \\
\hline 24 & 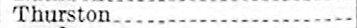 & Keith..... & 1,267 & 2,448 & 3,245 & 3,268 & & 3,271 & $\begin{array}{l}\text { Do. } \\
\text { Salt water. }\end{array}$ \\
\hline 25 & $\ldots$ do ........ & Fenner-Eddy. & 1,360 & 2,490 & 3,304 & 3,316 & & 3,327 & Do. \\
\hline 26 & Rathbone & MeCorkle.... & 1,537 & 2,600 & 3,687 & 3,721 & ........ & 3,754 & Do. \\
\hline 27 & Hornby & 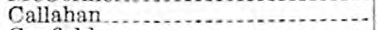 & 1,052 & 1,941 & 2,968 & 3,008 & & 3,065 & Dry. \\
\hline 28 & Wayne & 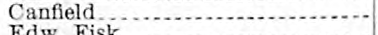 & $\begin{array}{r}895 \\
1.331\end{array}$ & $\begin{array}{r}547 \\
2,525\end{array}$ & $\begin{array}{l}1,473 \\
3,363\end{array}$ & $\begin{array}{l}1,548 \\
3,374\end{array}$ & $\cdots$ & 1,548 & $\begin{array}{c}\text { Salt water. } \\
\text { Do. }\end{array}$ \\
\hline 29 & Thurston.... & Edw. Fisk $\ldots$ & 1,331 & & & & & & \\
\hline
\end{tabular}

Tioga County

1 Owego .......................... Pumpelly _......................


Tompkins County

\begin{tabular}{|c|c|}
\hline $\begin{array}{c}\text { No. on } \\
\text { pl. } 5\end{array}$ & Town \\
\hline 1 & Lansing \\
\hline 2 & do \\
\hline $\begin{array}{l}3 \\
4\end{array}$ & Ithaca \\
\hline
\end{tabular}

\begin{tabular}{|c|c|c|c|c|c|c|c|c|}
\hline \multirow[b]{2}{*}{ Farm } & \multirow{2}{*}{$\begin{array}{c}\text { Approxi- } \\
\text { mate alti- } \\
\text { tude above } \\
\text { sea level } \\
\text { (feet) }\end{array}$} & \multicolumn{4}{|c|}{ Depth (feet) to top of- } & \multirow{2}{*}{ Total depth } & & \multirow[b]{2}{*}{ Status } \\
\hline & & $\begin{array}{c}\text { Tully lime- } \\
\text { stone }\end{array}$ & $\begin{array}{l}\text { Onondaga } \\
\text { limestone }\end{array}$ & $\begin{array}{l}\text { Oriskany } \\
\text { sandstone }\end{array}$ & $\begin{array}{l}\text { Medina } \\
\text { group }\end{array}$ & & & \\
\hline $\begin{array}{l}\text { Cayuga Rock Salt } \\
\text { Farkas } \\
\text { Remington }\end{array}$ & $\begin{array}{l}410 \\
850 \\
400 \\
396\end{array}$ & $\begin{array}{l}195 \\
365 \\
440\end{array}$ & $\begin{array}{r}936 \\
1,425 \\
1,555 \\
1,694\end{array}$ & $\begin{array}{l}1,012 \\
1,533 \\
1,650 \\
1,772\end{array}$ & 3,966 & $\begin{array}{l}1,964 \\
6,210 \\
2,192 \\
3,185\end{array}$ & $\begin{array}{l}\text { Salt. } \\
\text { Dry. } \\
\text { Salt. } \\
\text { Dry. }\end{array}$ & . \\
\hline
\end{tabular}

\section{Wyoming County}

\begin{tabular}{|c|c|c|c|c|c|c|c|c|c|}
\hline 1 & Java. & & 1,740 & & 1,990 & & 3,129 & 3,233 & Do. \\
\hline 2 & Arcade & & 1,665 & & 2,144 & & 3,286 & & Do. \\
\hline 3 & ..... do & & 1,500 & & 2,130 & & 3,285 & & Do. \\
\hline$\frac{4}{5}$ & ..... do $\ldots$ & & $\begin{array}{l}1,860 \\
500\end{array}$ & & 2,500 & & $\begin{array}{l}3,778 \\
2,918\end{array}$ & $\cdots$ & $\begin{array}{l}\text { Do. } \\
\text { Do. }\end{array}$ \\
\hline $\begin{array}{l}5 \\
6\end{array}$ & $\begin{array}{l}\text { Java } \\
\text { Middlebury }\end{array}$ & & $\begin{array}{l}1,500 \\
1,235\end{array}$ & & $\begin{array}{r}1,828 \\
630\end{array}$ & & $\begin{array}{l}2,918 \\
1,904\end{array}$ & & $\begin{array}{l}\text { Do. } \\
\text { Do. }\end{array}$ \\
\hline $\begin{array}{l}6 \\
7\end{array}$ & Covington. & & 954 & & 555 & & 1, ; & 1,236 & Salt. \\
\hline 8 & do & & 946 & & 555 & & & 1,241 & Do. \\
\hline $\begin{array}{r}9 \\
10\end{array}$ & Middlebury & $\ldots$ & $\begin{array}{l}992 \\
983\end{array}$ & & 673 & & ........ & 1,540 & Do. \\
\hline $\begin{array}{l}10 \\
11\end{array}$ & do & & $\begin{array}{r}983 \\
1.099\end{array}$ & & $\begin{array}{l}770 \\
935\end{array}$ & & (n....... & $\begin{array}{l}1,436 \\
1,609\end{array}$ & $\begin{array}{l}\text { Do. } \\
\text { Do. }\end{array}$ \\
\hline $\begin{array}{l}11 \\
12\end{array}$ & Warsaw $\ldots$ & $\cdots$ & $\begin{array}{l}1,099 \\
1,098\end{array}$ & & $\begin{array}{l}935 \\
956\end{array}$ & & n...... & 1,668 & Do. \\
\hline 13 & Arcade & & 1,600 & & 2,152 & & 3,268 & & Dry. \\
\hline 14 & Wethersfield. & ... & 1,390 & & 2,250 & & 3,430 & & $\begin{array}{l}\text { Do. } \\
\text { Do. }\end{array}$ \\
\hline 15 & do & & $\begin{array}{l}1,580 \\
148\end{array}$ & $\cdots$ & $\begin{array}{l}1,733 \\
1,339\end{array}$ & & $\begin{array}{l}2,873 \\
2,400\end{array}$ & $\ldots \ldots$ & $\begin{array}{l}\text { Do. } \\
\text { Do. }\end{array}$ \\
\hline $\begin{array}{l}16 \\
17\end{array}$ & Java do..... & & $\begin{array}{l}1,148 \\
1,102\end{array}$ & & $\begin{array}{l}1,339 \\
1,253\end{array}$ & & $\begin{array}{l}2,700 \\
2,323\end{array}$ & & Do. \\
\hline $\begin{array}{l}17 \\
18\end{array}$ & [.... do & & 1,224 & & 1,355 & & 2,424 & & Do. \\
\hline $\begin{array}{l}18 \\
19\end{array}$ & Sheldon. & ... & 979 & & 989 & & 2,059 & & Do. \\
\hline 20 & …. do ... & $\cdots$ & 1,315 & & 1,275 & & $\begin{array}{l}2,364 \\
2,485\end{array}$ & & Do. \\
\hline 21 & ............. do do & & $\begin{array}{l}1,483 \\
1,248\end{array}$ & ... & $\begin{array}{l}1,404 \\
1,150\end{array}$ & & 2,191 & & Do. \\
\hline $\begin{array}{l}22 \\
23\end{array}$ & _..... do & & $\begin{array}{l}1,248 \\
1,049\end{array}$ & $\cdots$ & $\begin{array}{r}1,150 \\
968\end{array}$ & & 2,155 & & Do. \\
\hline $\begin{array}{l}23 \\
24\end{array}$ & Pike & 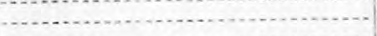 & 1,490 & & 2,061 & & 3,388 & 3,508 & Do. \\
\hline 25 & Gainesville... & ... & 1,600 & & 1,952 & & $\begin{array}{l}3,208 \\
3,105\end{array}$ & $\begin{array}{l}3,361 \\
3,214\end{array}$ & $\begin{array}{l}\text { Do. } \\
\text { Do. }\end{array}$ \\
\hline 26 & Castile ...... & $\cdots+$ & $\begin{array}{l}1,515 \\
1,400\end{array}$ & & $\begin{array}{l}1,821 \\
1,551\end{array}$ & & 2,744 & $0,2 \pi$ & Do. \\
\hline 27 & $\begin{array}{l}\text { Gainesville... } \\
\text { Eagle }\end{array}$ & .... & $\begin{array}{l}1,400 \\
1,820\end{array}$ & & $2,447(?)$ & & 3,626 & & Do. \\
\hline $\begin{array}{l}28 \\
29\end{array}$ & $\begin{array}{l}\text { Eagle } \\
\text { Warsaw....... }\end{array}$ & & 1,125 & & $\begin{array}{l}1,028 \\
1,230\end{array}$ & & & $\begin{array}{l}1.701 \\
1,879\end{array}$ & Salt. Do. \\
\hline 30 & .... do do.... & & 1,324 & & & & & & \\
\hline & & (n) & 1,360 & & i, 462 & & $\ldots$. & 2,0211 & \\
\hline 33 & Gainesville... & & 1,306 & & 1,450 & & & 2,511 & Do. \\
\hline 34 & Castile ........ & 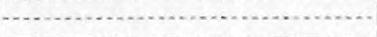 & 1,390 & & 1,775 & & & 2,525 & Do. \\
\hline 35 & Attica ....... & ........ & 1,160 & & 695 & & 1,780 & 1,880 & Dry. \\
\hline 36 & Bennington... & $m$ & 1,178 & ... & 800 & & 1,800 & $\cdots$ & Do. \\
\hline 37 & do do & monumon & 1,243 & & 885 & & 1,930 & $\ldots$ & Do. \\
\hline 38 & ..... do do $\ldots . . .$. & (n)............. & 1,306 & .. & 1,025 & & 2,068 & & Do. \\
\hline 39 & 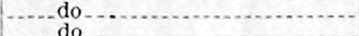 & n.......... & 1,141 & & 788 & & 1,806 & 2 & Do. \\
\hline 40 & - ndo & $\cdots$ & 1,145 & & 770 & & 1,778 & & Do. \\
\hline 41 & 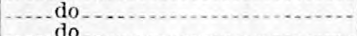 & enos & 939 & ... & 540 & & 1,521 & .... & Do. \\
\hline 42 & ..... do do & (n) & 989 & & 515 & & 1,486 & .... & Do. \\
\hline 43 & do & (n).................. & 1,240 & (n..... & 942 & (n). & 1,955 & .. & Do. \\
\hline 44 & Attica do & (n)............. & 1,130 & & 801 & -- & 1,763 & & Do. \\
\hline 45 & $\begin{array}{l}\text { Attica } \\
\text { Gainesville }\end{array}$ & (n)............... & 980 & .... & $\begin{array}{r}550 \\
2066\end{array}$ & & 1,605 & 1,708 & Gas. \\
\hline $\begin{array}{l}46 \\
47\end{array}$ & $\begin{array}{l}\text { Gamesville } \\
\text { Attica }\end{array}$ & Newell & $\begin{array}{l}1,770 \\
1,310\end{array}$ & $\cdots$ & $\begin{array}{r}2,066 \\
880\end{array}$ & (n......... & 1.943 & 2,040 & Dry. \\
\hline 48 & do & Carman ..................... & 1,310 & ........ & 875 & $\cdots$ & 1,962 & 2,047 & Do. \\
\hline 49 & 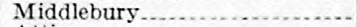 & 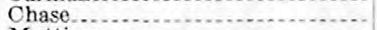 & 1,180 & (n..... & 819 & $\cdots$ & 2,000 & 2,121 & Do. \\
\hline 50 & Attica & Mattison & 1,040 & & 710 & & 1,780 & 1,885 & Do. \\
\hline
\end{tabular}

\section{Yates County}

\begin{tabular}{|c|c|c|c|c|c|c|c|c|c|}
\hline 1 & Starkey & Andrus. & 1,125 & 776 & 1,637 & 1.687 & & & Dry. \\
\hline 2 & ..... do - & Seneca.. & 1,260 & 808 & 1,664 & 1,723 & & 1,822 & Do. \\
\hline 3 & do $10 . . . .$. & ..... do... & 1,345 & 887 & 1,738 & & & 1,836 & Do. \\
\hline 4 & Milo & Norris . & 819 & 303 & 1,093 & 1,132 & & & Do. \\
\hline 5 & ..... do ... & Sanderson & 838 & $248(?)$ & 1,005 & 1, $102(?)$ & & $1,560(?)$ & Salt water. \\
\hline 6 & ..... do & Cook ....... & 1. 274 & 702 & 1,512 & 1,548 & & 1,576 & Do. \\
\hline 7 & ..... do .... & Van Gelder. & 1.333 & 736 & 1,545 & 1,587 & & 1,589 & Do. \\
\hline 8 & $\ldots$ do $\ldots . . .$. & Ward ................ & 1.244 & 632 & 1,433 & 1,499 & & 1,504 & Dry. \\
\hline 9 & Barrington............... & Stoutenberg.... & 1,081 & 496 & 1. 298 & 1,383 & & 1,414 & Do. \\
\hline 10 & do & Bloss. & 1.407 & 880 & 1,646 & 1,715 & & 1,747 & Salt water. \\
\hline 11 & $\ldots$ do & Thayer & 1,381 & 852 & 1. 701 & 1,756 & .. & 1,802 & Dr: \\
\hline $11 \mathrm{a}$ & $\ldots$ do $\ldots . . .$. & Bellis... & 1,478 & 1,212 & 2,055 & 2,117 & & 2,123 & Salt water. \\
\hline 12 & . do $\ldots$ & Beyea... & 1,325 & 930 & 1,821 & 1,940 & & 2,000 & Dry. \\
\hline 14 & _... do 0 , & Millard ......... & 1,338 & 1,012 & 1.907 & 1,967 & & 1,976 & Salt water. \\
\hline 15 & do & 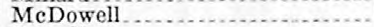 & 1,676 & $1,375(?)$ & 1,217 & 2,284 & & 2,291 & Do. \\
\hline 16 & Jerusaiem & Russell .............................. & 983 & 625 & 1,360 & 1,468 & 3,300 & 3,506 & Dry. \\
\hline 17 & Starkey ................ & Hall...... & 1,400 & 1,100 & 1,985 & 2.078 & & 2,106 & Salt water. \\
\hline 18 & Torrey & 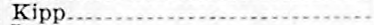 & 888 & & 958 & 973 & & & Dry. \\
\hline 19 & Jerusalem ................... & Lee. & 1,366 & 1,140 & 1,971 & 2,036 & & & Do. \\
\hline 20 & $\ldots$ do $\ldots$ & (n) & 1,410 & 1,102 & 1,818 & 1,899 & & & Salt water. \\
\hline 21 & Starkey & Peele ... & 1,178 & 900 & 1,852 & 1,945 & (................... & 3,403 & Dry. \\
\hline 22 & Barrington ....................... & Weldy........... & 1,477 & 1,187 & 2,044 & 2,093 & (2) & & Salt water. \\
\hline
\end{tabular}





\section{INDEX}

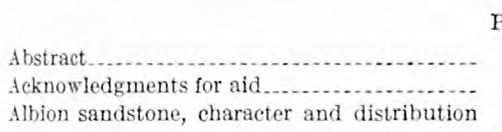
gas in $15,77-78$

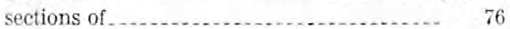

Allegany County, records of wells in ........ 79

Broome County, records of wells in ........ 80

Cattaraugus County, gas in ............... 75 records of wells in ................... 80

Cayuga County, records of wells in ......... 81

Chautauqua County, gas in ................. 75 records of wells in ................... $81-82$

Chemung County, records of wells in ...... 82

Convergence of the strata ............ 73, pl. 6

Cortland County, records of wells in ........ 82

Cuylerville, section at ..................... 76

Devonian rocks, gas in ...................... 75

Dunkirk shale, convergence of Onondaga limestone and

Erie County, gas in gas wells and dry holes in, location of .... pl. 8 records of wells in ................. $82-85$

Federal Emergency Administration of Public Works, allotment of funds by ....

Gas, occurrence of $71,72,75,76,77$ relation of occurrence of, to lithology ..... $75-78$ relation of occurrence of, to structure. 75 , pls. $7-8$

Gas-producing areas, outline of.

Genesee County, gas in. records of wells in

Gray band, age and thickness of.

Key beds, convergence of features of

$73, \mathrm{pl}, 6$

Lithology, relation of, to occurrence of gas .... 75-78

livingston County, records of wells in....... section in

Hedina and Oriskany gas fields, structure of, comparison of

Medina group, age of convergence of Onondaga limestone and $73, \mathrm{pl}, 6$ depth to. - 79-91 distribution 0 f $75-76$ gas in $75-78$ key horizon for gas-bearing beds in ...... 72-73 Ionroe County, records of wells in. $86-87$

Niagara gorge, section in
Olean, thickness of rocks in vicinity of ...... 73-74

Onondaga County, records of wells in ...... 87

Onondaga limestone, character and distribution of ........................ 72 convergence of Dunkirk shale and....... 73 convergence of Medina group and..... 73, pl. 6 convergence of Tully limestone and .... 73, pl. 6 depth to........................ 74, 79-91 range in altitude of .................... 74

Ontario County, records of wells in ......... 87

Ordovician rocks, gas in .................... 75

Oriskany and Medina gas fields, structure of, comparison of . .

Oriskany sandstone, character and distribution of ..................... 72, pl. 5

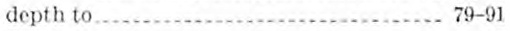

ges in ................................ 72

Oswego sandstone, age of .................... 70,71

Pre-Cambrian rocks, depth to ............. 73-74

Queenston shale, age of ................... 70

Red Medina sandstone, gas in ............. 77-78

Schuyler County, records of wells in ........ 88

Seneca County, records of wells in.......... 88

Silurian rocks, gas in ....................... 75

Sterling salt mine, section at ............... 76

Steuben County, records of wells in ......... 89

Stratigraphy of the area ................. $70-74$

Structure, general features of ....... 74-75, pls. 7-8 relation of, to occurrence of gas .... 75 , pls. 7-8

Structure in Medina and Oriskany gas fields, comparison of ................. 75

Thorold sandstone, age and thickness of ..... 73

Tioga County, records of wells in ......... 89

Tompkins County, records of wells in ....... 90

Tully limestone, character and distribution of _ $\quad 72$ convergence of Onondaga limestone and. 73, pl. 6

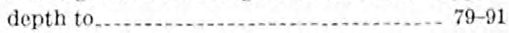

Wells, location of ..................... pls. $5,7-8$ records of ........................... 79-91

Whirlpool sandstone member, character of ... 77 gas in ..................... $76,77-78$

White Medina sandstone member, character of ......... 77 gas in ............... $77-78$

Wyoming County, gas in ...................... 75 records of wells in f.................. 90-91

76 Yates County, records of wells in .......... 91 